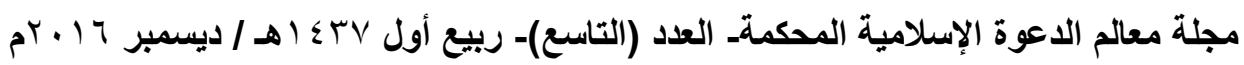

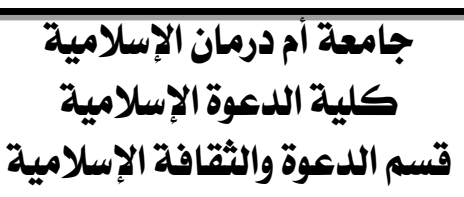

طرق جذب غير المسلمين إلى الإسلام

حسين إسحاق داؤد يوستور

$p r+|r=| \varepsilon r \Lambda$ 


\section{طرق جذب غير المسلمين إلى الإسلام}

مقدمة:

الحمد لله رب العـالمين، والصـلاة والسـلام على رسـول الله الأمسين وعلى آلـه

وصحابته أجمعين، وبعد:

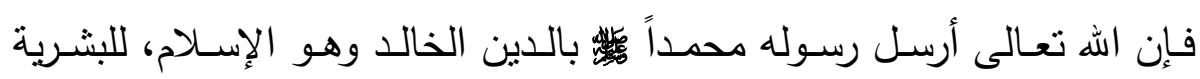

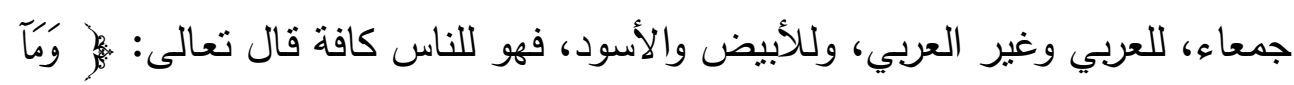

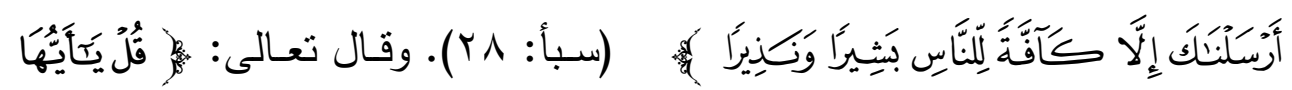

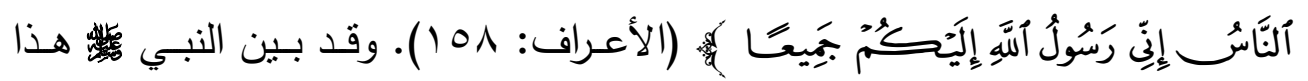

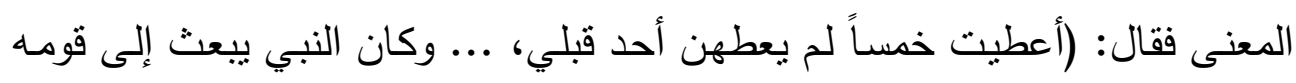

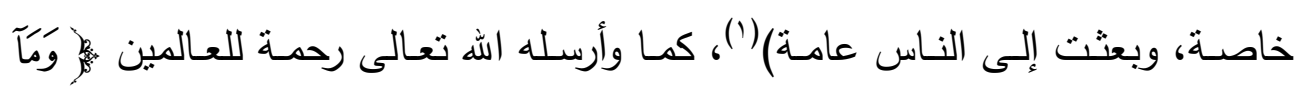

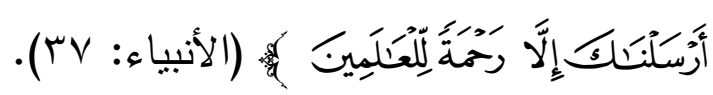

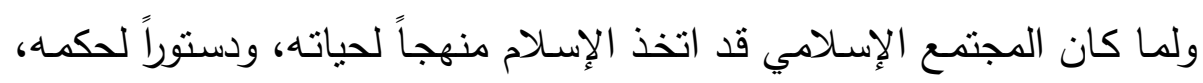

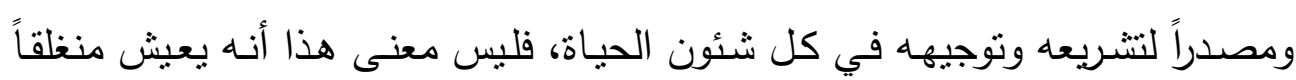

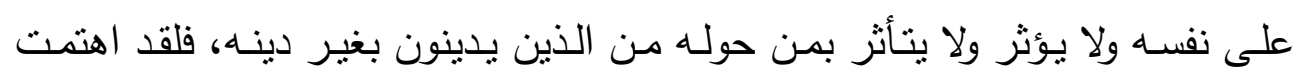

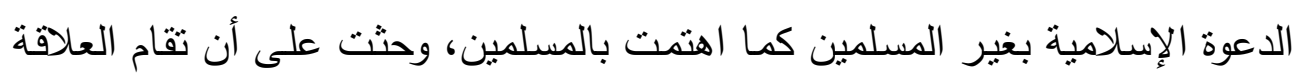

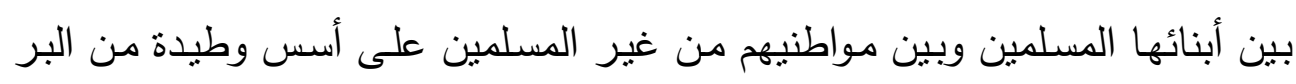
والرحمة والعدالة، وهي أسس لم تعرفها البشرية قبل الإسلام.

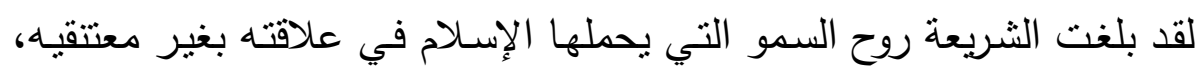

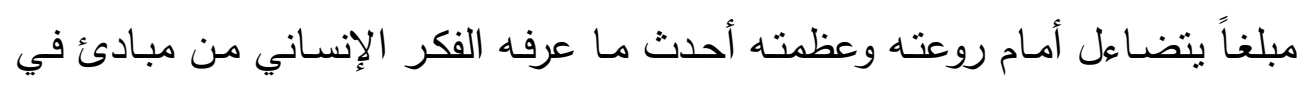
شأن علاقة مواطني الدولة فيما بينهم، وفي شأن العلاقات الدولية العامة.

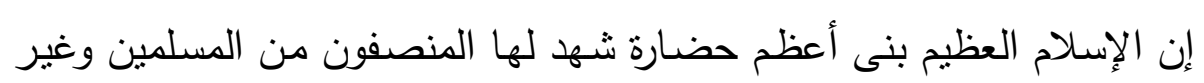

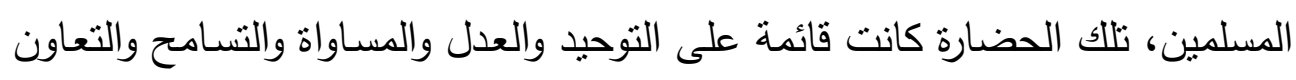

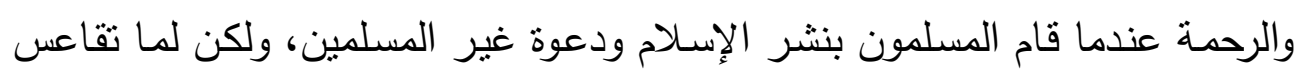


المسلمون عن هذا الواجب تأخروا، لذلك جاء هذا البحث ليشحذ الهمم من جديد ويدعو المسلمين للقيام بواجبهم تجاه الأمم بدعوتهم وجذبهر للإسلام.

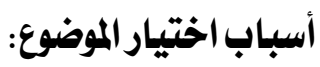

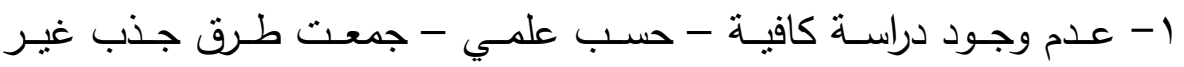
المسلمين إلى الإسلام في العصر الحالي. r- عرض طرائق واقعية لجذب غير المسلمين إلى الإسلام.

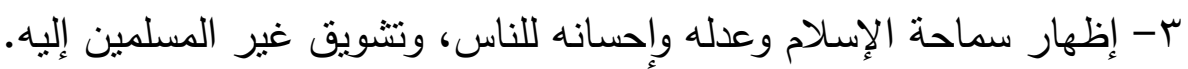


1- بيان أن الدعوة الإسلامية دعوة عالمية للناس كافة.

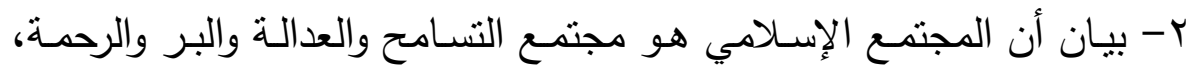

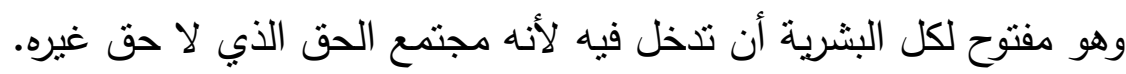

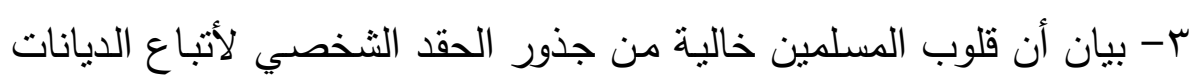

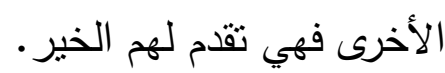

ع- نقل الدفاهيم والأفكار الصحيحة عن الإسـام إلى الدجتمعات التي تتعدد

تشويه صورته ونشر المفاهيم المغلوطة عنه.

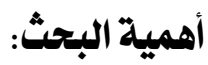

تكمن أهميـة البحث في كونه يلقي الضوء على قضية مهمة لم تعط حظها

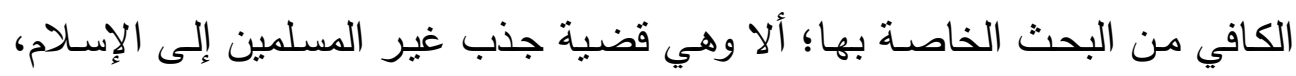

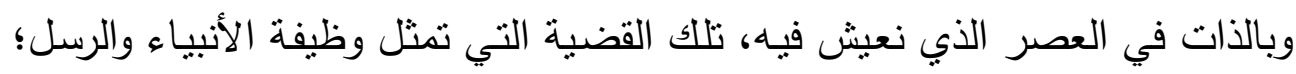
لأن الدعوة إلى الإسلام وجذب الناس إليه لا تكون أصلاً إلا لغير المسلمين.

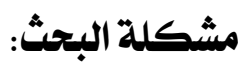

يمثل القصور في طرق عرض الإسـلام على غير المسلمين، ووهن الجهود الواجب بذلها في ذلك السبيل، والضعف الكبير في إيجاد الطرائق الفعالة في جذب علب الطبل غير المسلمين إلى الإسـام، والعجز في حل المشـاكل التي تواجـه غير المسـلمين وتمنعهم من الدخول في الإسلام، فضلاً عن الانطباعات المشبوهة عن صورة الإسلام

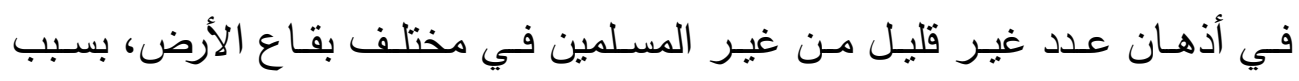
الدعايات المغرضة، والإعلام الحاقد، يمثل مشاكل هائلة يجب بحثنها بعمق وعلمية، لإيجـاد الحلول الواقعيـة لها. وذلك مـن خـلادل الإجابـات الموضـوعية على الأسـئلة

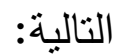

1- ما الحقوق الإنسانية المشتركة بين كافة الناس؟ 
r- ما طرق جذب غير المسلمين إلى الإسلام داخل الدولة الإسلامية؟

r- ما طرق جذب غير المسلمين إلى الإسلام خارج الدولة الإسلامية؟

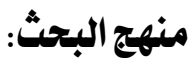

لقد اتبع الباحث المنهج الوصفي، ثم التحليلي في تحليل النصوص والاستتباط

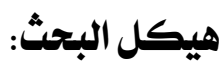

لقد قسمت هذا البحث إلى مقدمة وثلاثة مباحث وخاتمـة وفهارس على النحو

المبحث الأول: الحقوق الإنسانية المشتركة بين كافة الناس.

المبحث الثاني: طرق جذب غير المسلمين الذين في داخل الدولة الإسلامية

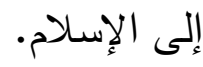

المبحث الثالث: طرق جذب غير المسلمين الذين خارج الدولة الإنسلامية إلى

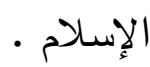

الخاتمة وتتثمل النتائج والتوصيات.

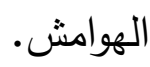

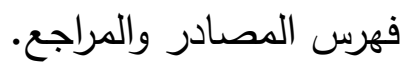




\section{هستخلص البحث}

جاء هذا البحث لبيان الطرق التي وضعها الإسلام في كيفية التعامل مـ غير المسلمين وجذبهم إلى الإسلام، ومن ثم بين هذا البحث التعاليم الإسلامية التي قررت التهايه

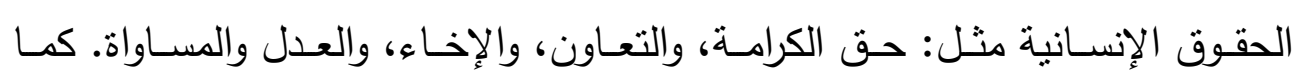
استعرض هذا البحث الطرق التي تجذب غير المسلمين إلى الإسلام من الموجودين

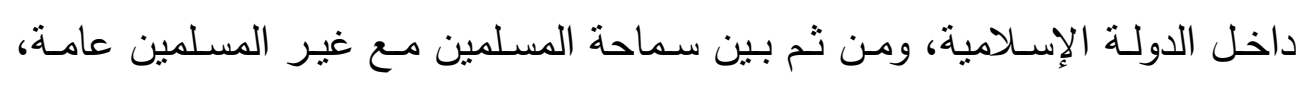

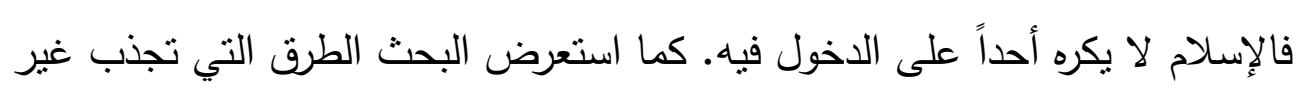

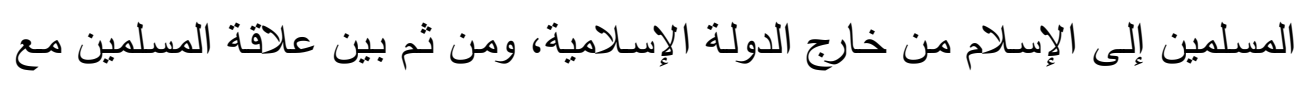

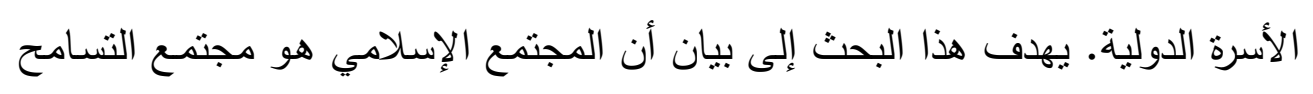

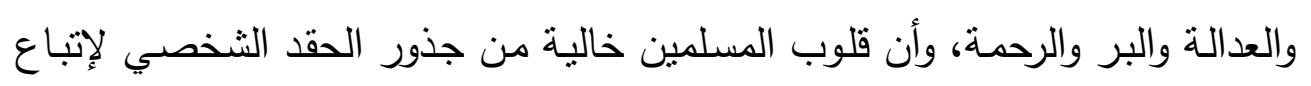
الديانات الأخرى فهي تقدم لهم الخير • وعليه لقد اتبع الباحث المنهج الوصفي ثن التحليلي للتوصل على النتائج والتوصيات التي تفيد في هذا البحث. وقد توصل الباحث إلى أن اختلاف الدين لبس مصدر خصومة واستعداء، وسماحة الإسـلام تتضـح مـع غيـر المسلمين مـن خـلال إحسـان القول لهم، والإحسـان إلـى أسـراهم

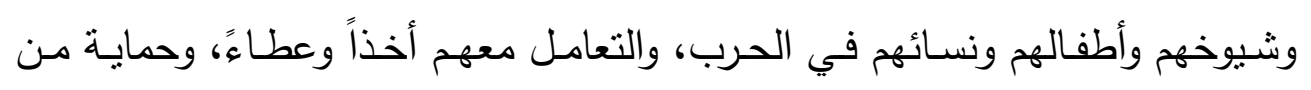

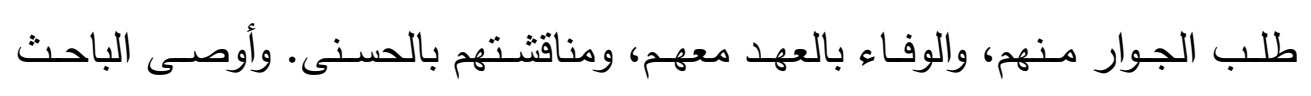

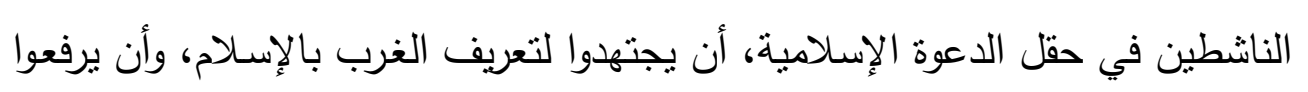

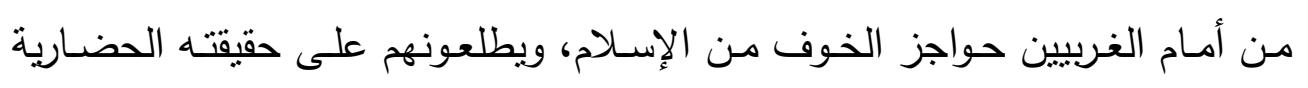
والإنسانية. 


\section{Abstract}

This research to explain show the methods of Islam had laid in how to deal with non- Muslims and to attract them to Islam, then this research clarify the Islamic teachings which confirm the human rights: such as right of dignity, cooperation, brotherhood, justice and equality. The research also reviews the methods which can attract non - Muslims who live in the territory of Islam state to Islam, the show the generosity of Muslims with non - Muslims generally, so Islam does not force any one to be Muslim. The research has also reviewed the methods that attract non - Muslims who live outside Islamic state to Islam, and show Muslims relationship with international community. This research aims at showing that the Islamic community is the community of tolerant, righteousness and mercy, and that the Muslims hearts are empty from roots of personal hatred towards the followers of other religions. The researcher followed the descriptive method then the analytical one to find the results and recommendations that may be useful in this research. The researcher found out that the differences between religions is not a matter deserve an antagonism and enmity, the generosity of Islam appear clearly with non - Muslims through good saying to them and good treatment with their prisoners, aged, children and their women in the war and alternate the benefits with them, protect them, keep words with them and discuss them kindly. The researcher recommended the Activists in field of Islamic Dawa to do their best to introduce Islam to the West, and lift the barriers of Islam- Phobia from westerner and show them the its civilized and humanitarian fact. 


\section{المبحث الأول \\ المقوق الإنسانية المشتركة بين كافة الناس

$$
\text { المطلب الأول : الكرامة الإنسانية: }
$$

إن الإسلام دين يدعو إلى كل خير ، وينهى عن كل شر، يدعو إلى الإحسان

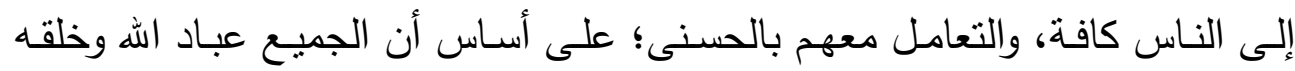
تعالى، وأن أحب الخلق إلى الله أنفعهم وأجداهم لعباده.

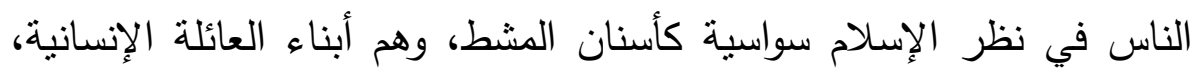

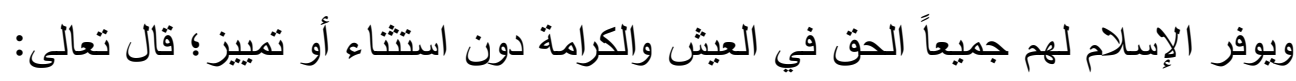

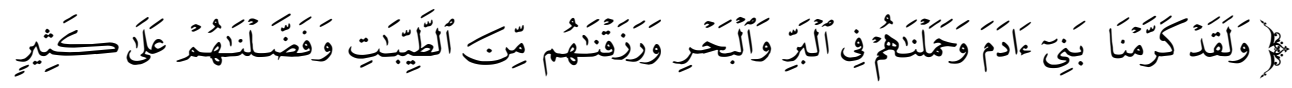

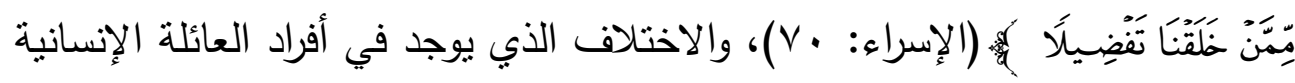

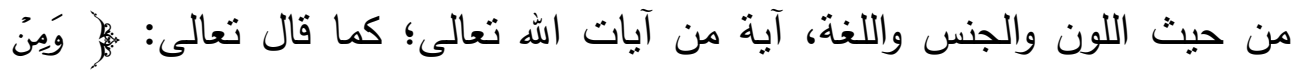

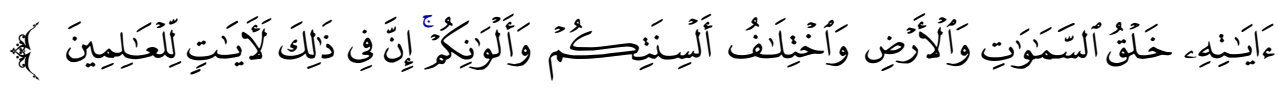

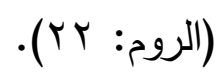

وهذا الاختلاف ليس مدعاة للتنافر والتتاكر ، بل هو سبب للتعارف والتعاضد

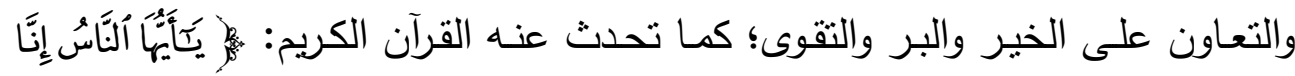

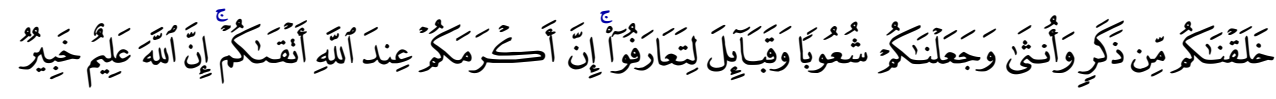

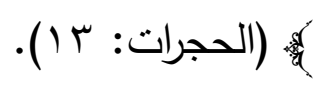

لقد أوجب الإسـلام على المسلمين أن براعوا الكرامـة الإنسانية التي وهبها الله

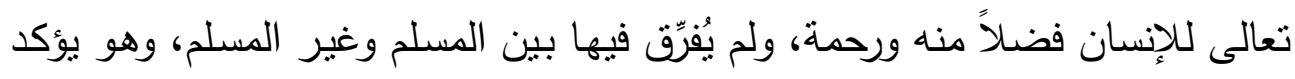

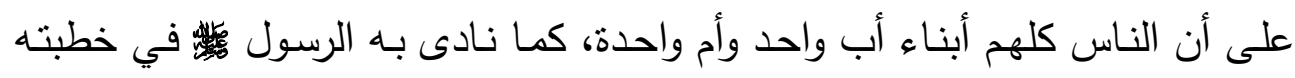

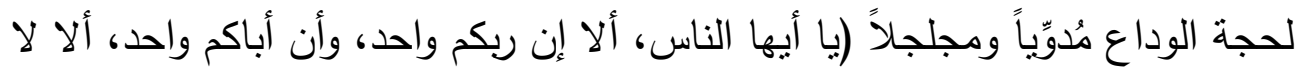


فضل لعربي على عجمي، ولا لعجمي على عربي، ولا لأحمر على أسود، ولا لأسود

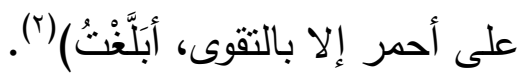

إن الإنسان في نظر الإسـام مُكَّرم، بصرف النظر عن أصله وفصله، دينه

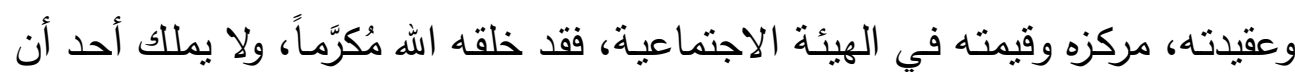

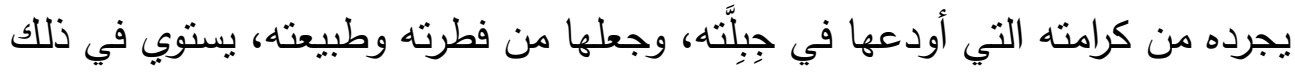

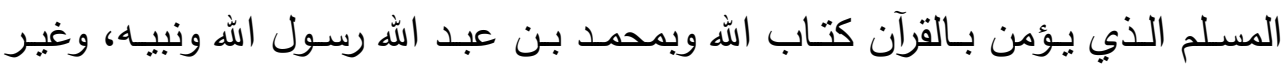

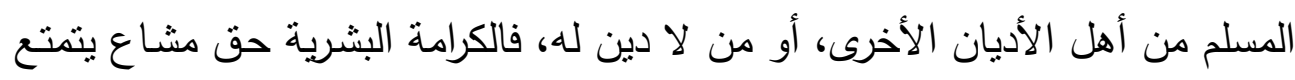

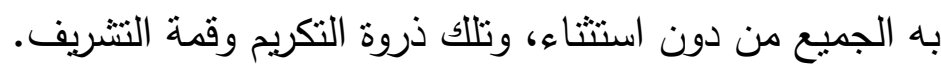

لقد قامت مبادئ الإسـام وتعاليمـه وقيهـه كلها على احترام الكرامـة الإنسانية وصونها وحفظها، وعلى تعميق الثُعور الإنساني بهذه الكرامـة، ومـا دامت الرسـالة

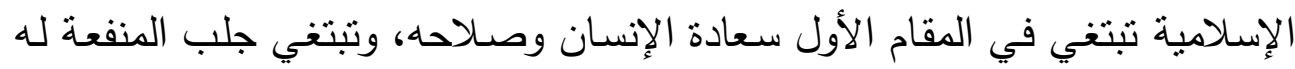
ودري المفسـة عنـه، فإن هذه المقاصــ الثشريفة هي منتهى التكريم للإنسـان بكل الإنل

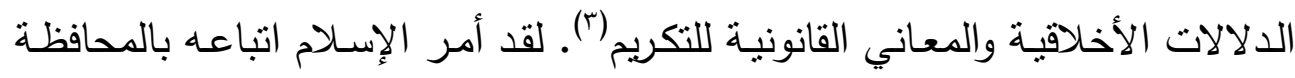
على كرامة غير المسلمين ومراعاة مشاعرهم، ونهى عن جرح عواطفهم؛ فقال الرب -

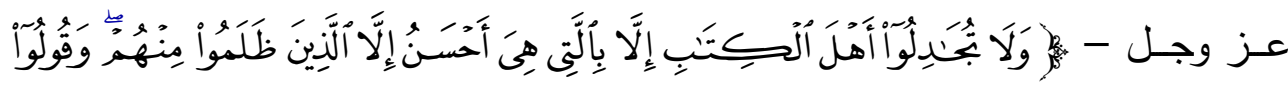

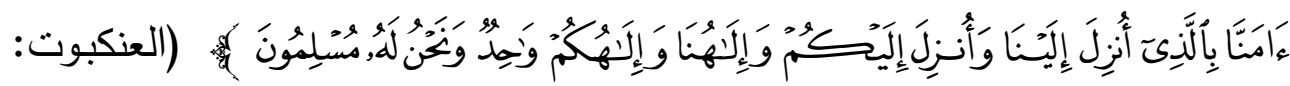

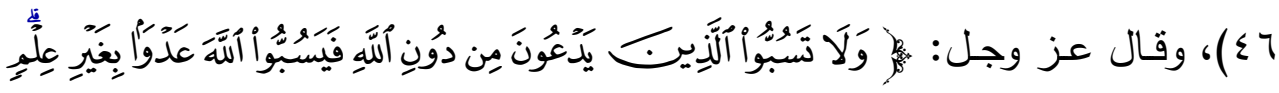

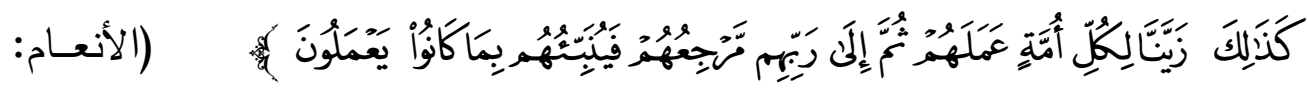

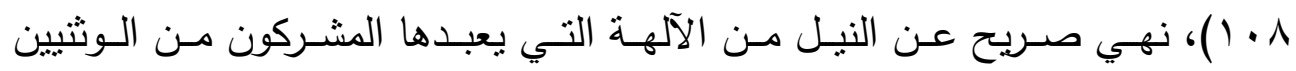

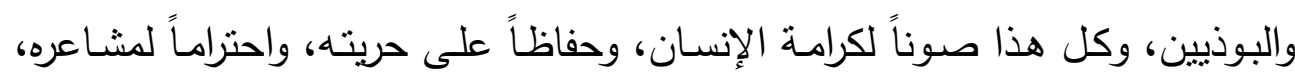

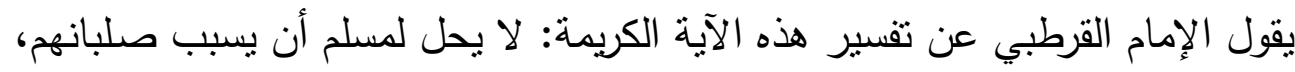


ولا دينهم، ولا كنائسهم، ولا يتعرض إلى ما يؤدي إلى ذللك؛ لأنه بمنزلة البعث على

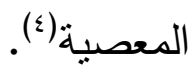

وحفظ الكرامة الإنسانية يتجلى لنا في النعامل النبوي مع غير المسلمين حتى النى

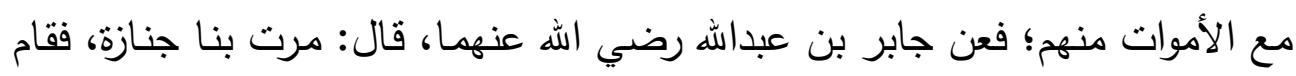

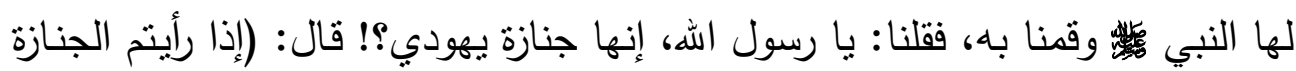

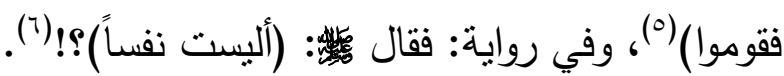

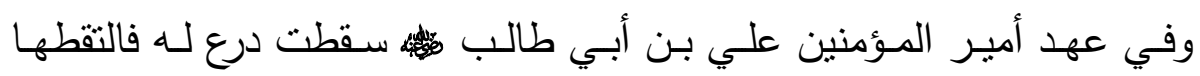

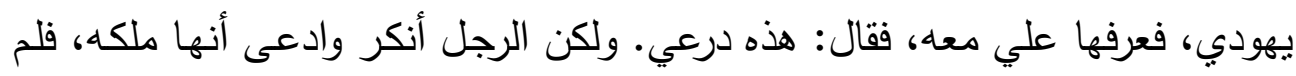

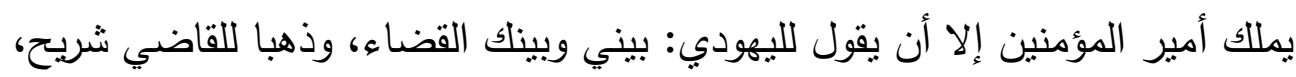
وبعد سماع الخصمين طلب القاضي من الخليفة بينة على دعواه، أي: شهوداً، فلم لمأل

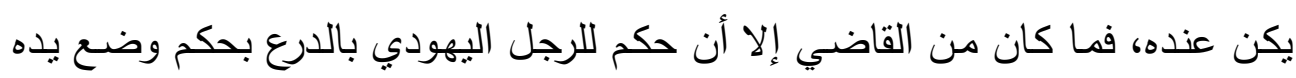

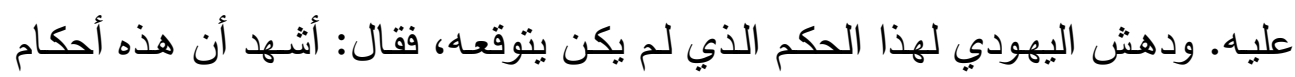

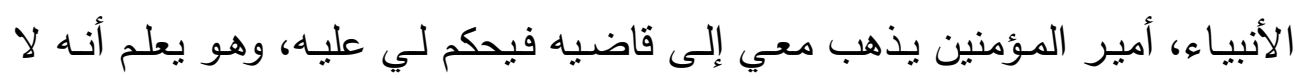

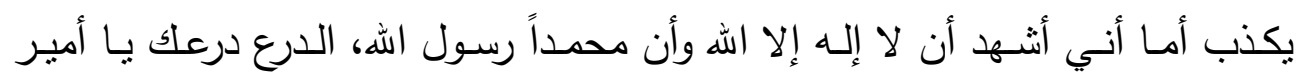

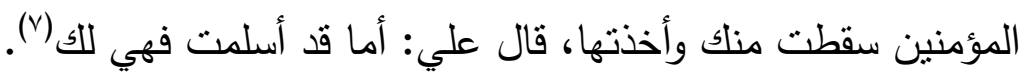

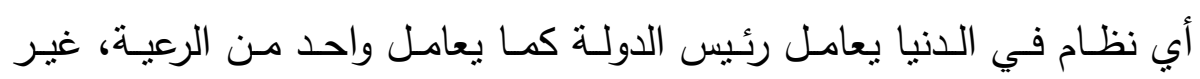
الإسلام؟

\section{الإطلب الثاني: الإخاء الإنساني:}

هذا الإخاء البشري العام قرره الإسـلام بناء على أن البشر جميعاً أبناء رجل الإنل

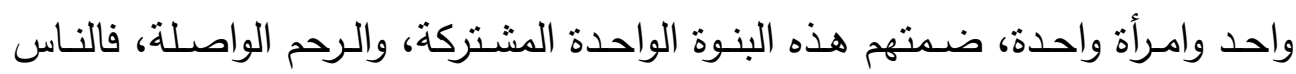

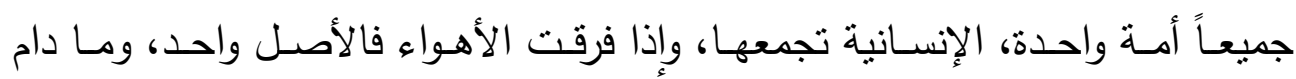
الأصل واحداً فالوحدة شاملة، وقد جاء ذلك في آيات عدة، ففي سورة النساء تصرح

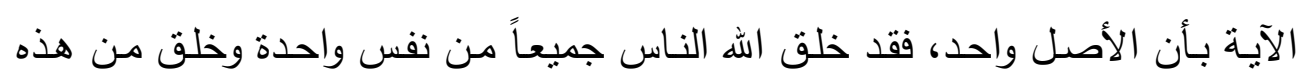

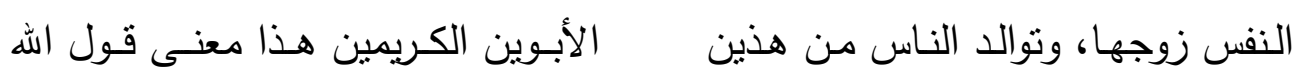




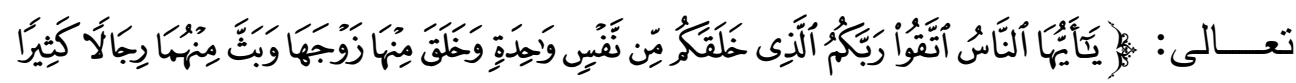

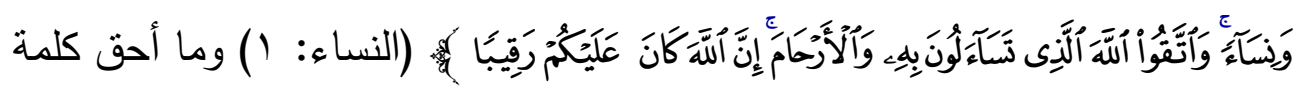

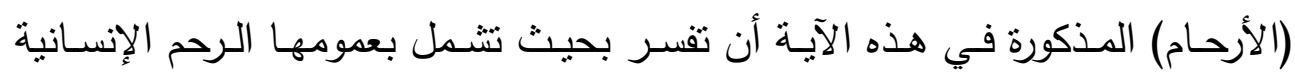

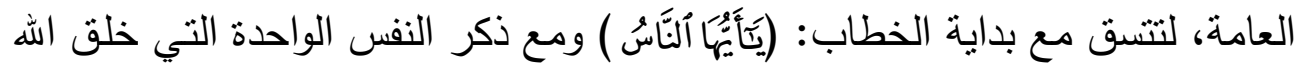

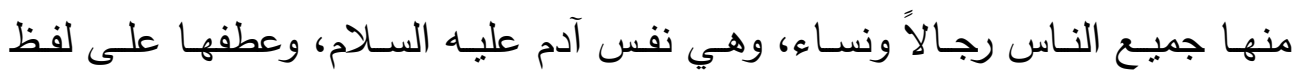
الجلالة: (الله) في هذا المقام يدل على أن لهذه الأرحام شأناً أب شأن (^).

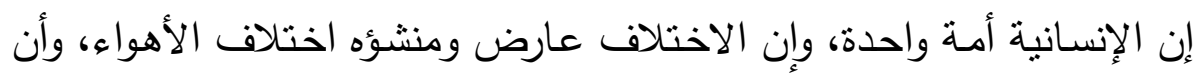

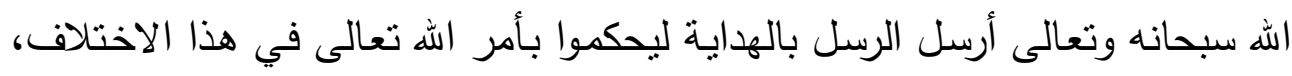
ولييينوا لهم طريق الهاية، فيسلكه من تغلب على هواه، ويضل الآخر ويشقى. قال

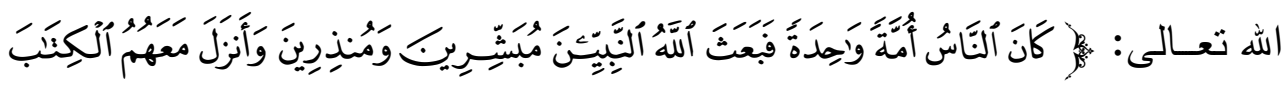

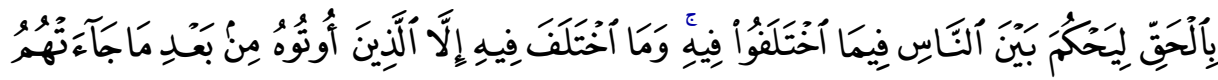

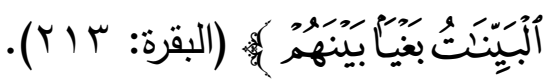

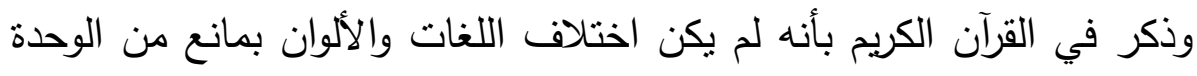

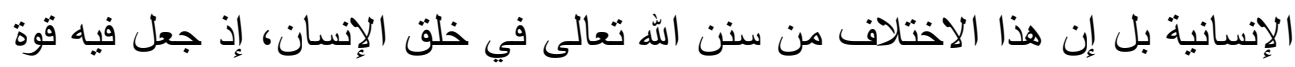

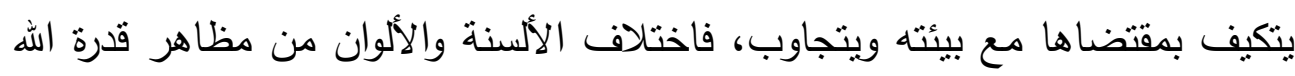

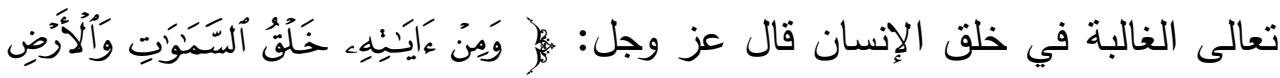

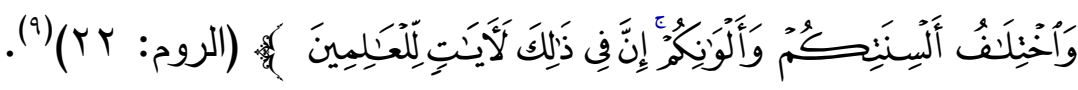
وإن اختلاف الناس شعوباً وقبائل لم يكن ليتقاتلوا ويختلفوا ولكن لينّن ليتعارفوا

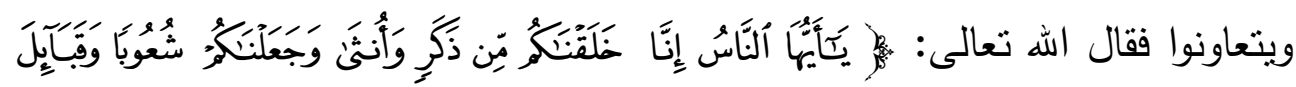

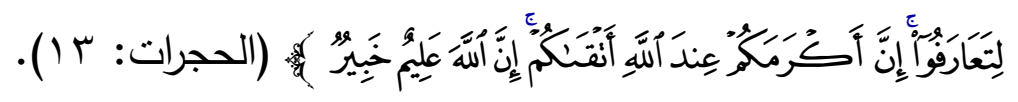

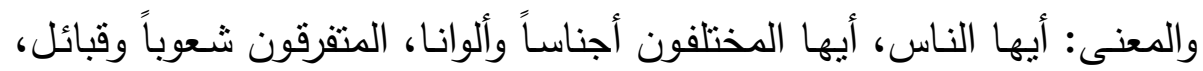
إنكم من أصل واحد، فلا تختلفوا، ولا تتفرقوا، ولا تخاصموا، ولا تذهبوا بدداً ('). 


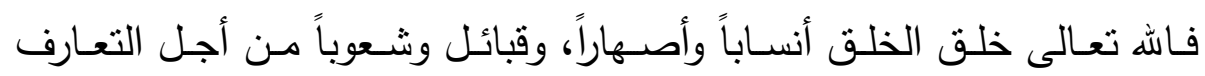

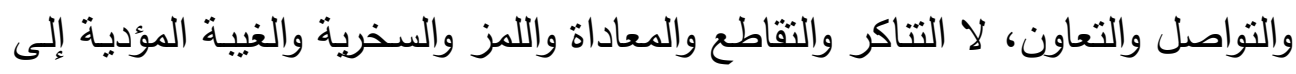
التتازع والعداوة، ولا التفاخر بالأنساب والأعراق والأصول، فكل ذلإنك اعتبارات وهمية

مصطنعة تعارض مع وحدة الأصل والمنشأ الإنساني (1').

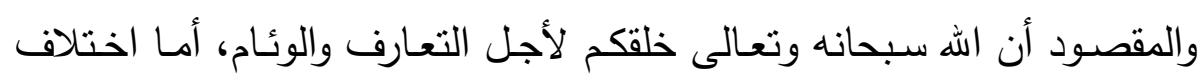

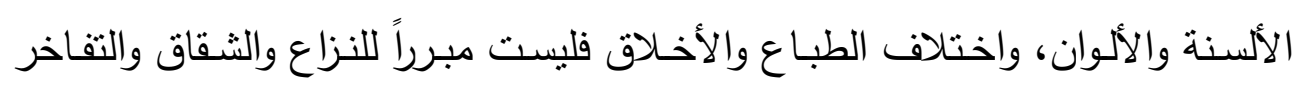
والتفاضل.

فإن كان هناك تفاضل بين الناس وتفاخر بالأنساب، فالأكرم عند الله، والأرفع

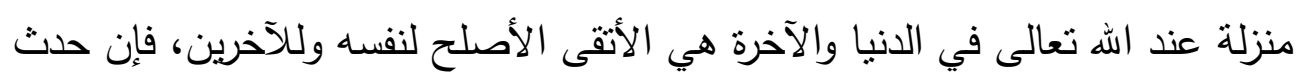

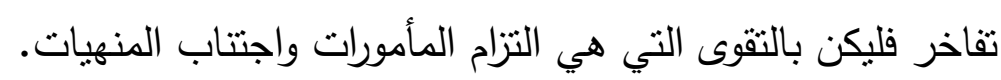

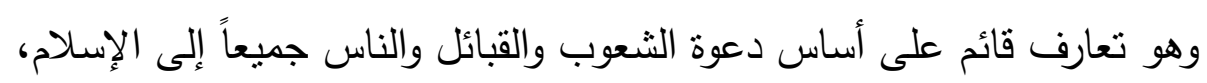

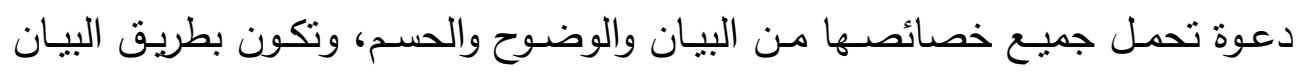

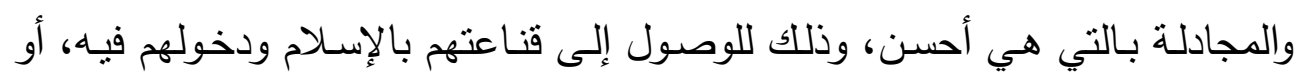

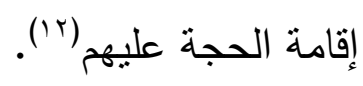

\section{المطلب الثالث: التعاون الإنساني:}

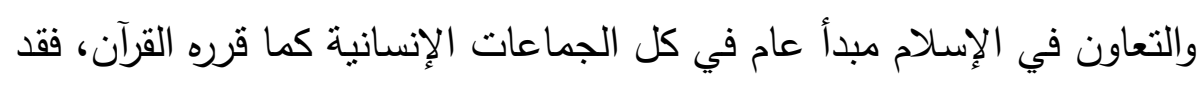

جاء في سورة المائدة الحث على التعاون المطلق على البر ومنع التعاون على الإثم

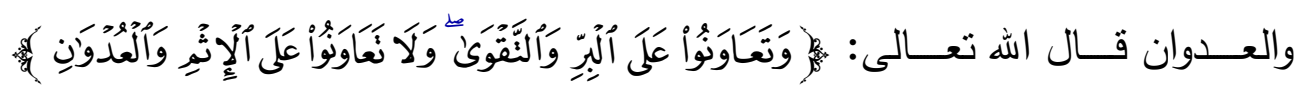

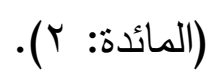

ولقد نفذ النبي

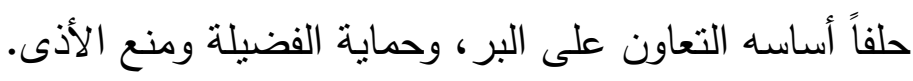

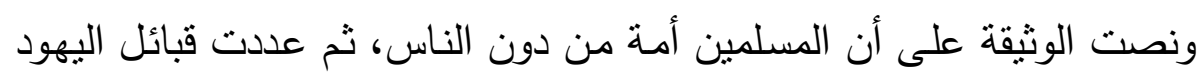

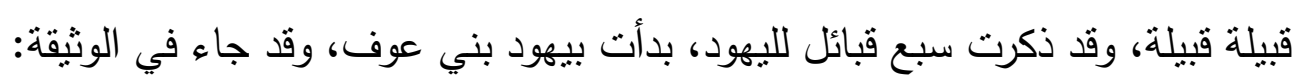

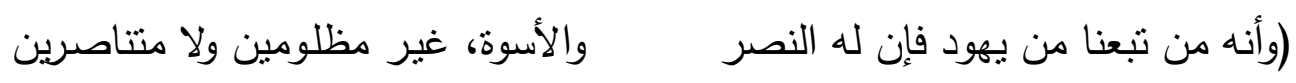


عليهم، وإن يهود بني عوف أمة مع المؤمنين لليهود دينهم، وللمسلمين دينهم .. وأن

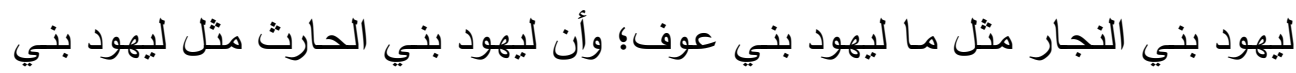

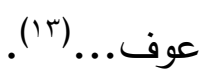
إن المعاهـدة السـابقة اعتبـرت اليهـود جـزءاً مـن مـواطني الدولـة الإسـلامية،

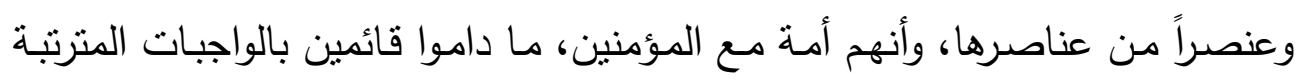
عليهم. ونحن نرى أن هذه الوثيقة تتسجم انسجاماً تاماً مع ما قرره الإسلام في مبادئه

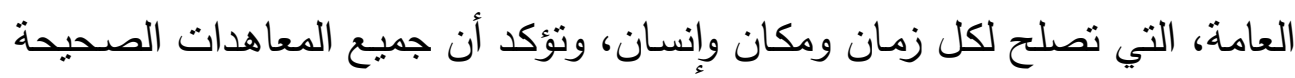

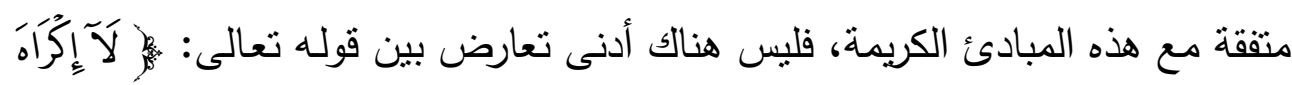

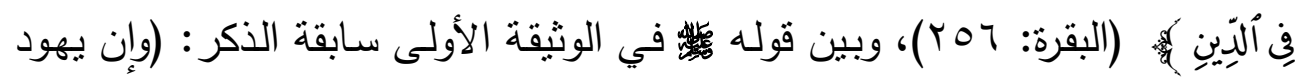
بني عوف أمة مع المؤمنين). وقد يسأل سائل إذاً لماذا أجلى النبي محمد اليهود عن المدينة؟

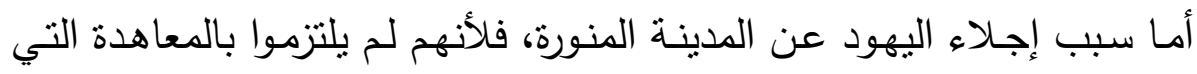
أبرمها الرسول حددنها بل وقفوا مواقف عدائية أيضاً.

قال ابن حجر: (وكان الكفار بعد الهجرة مع النبي إس على ثلاثة أقسام: قسم

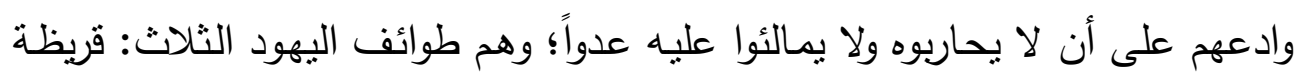
والنضير وقينقاع ...، فكان أول من نقض العهد من اليهود بني قينقاع، فحاربهم ...

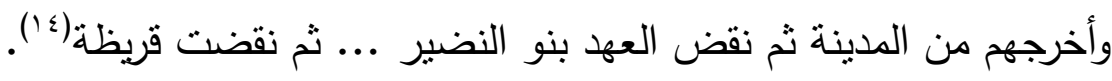

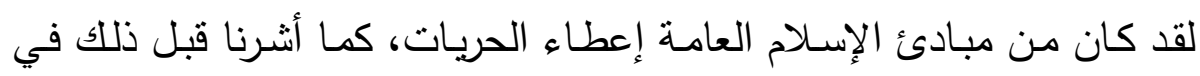

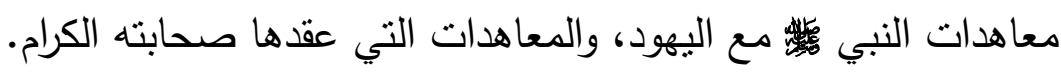

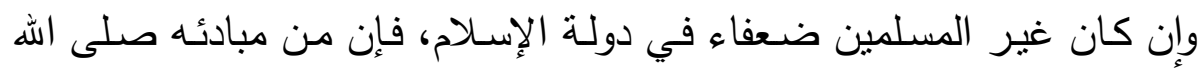


عليه وسلم التعاون على نصرة الضعيف، فيعلن عبداً.

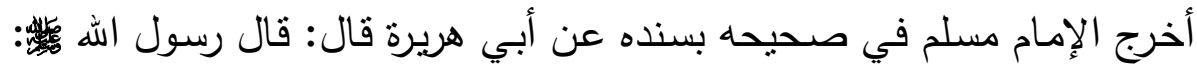
(والله في عون العبد ما كان العبد في عون أخيه)(10) ولم يعين ذللك الأخ بل عمدها، فيعم الأخوة الإنسانية، ولا يقتصر على الأخوة الدينية أو الإقليمية.

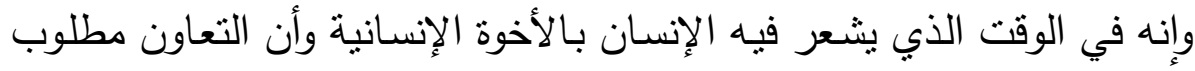

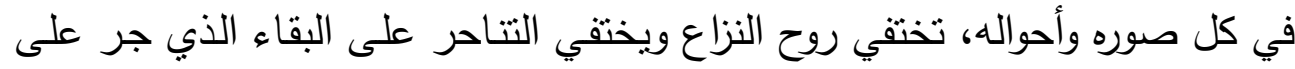

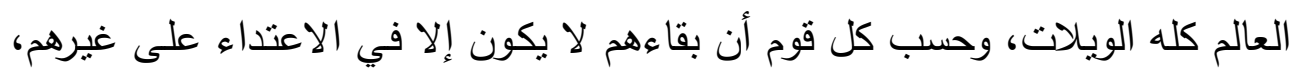

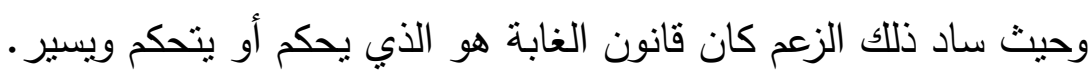

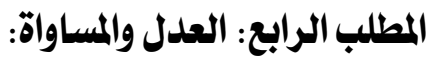

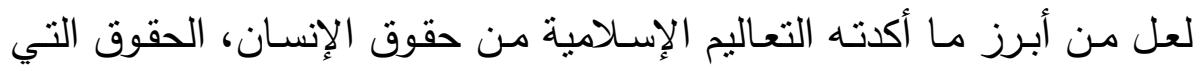

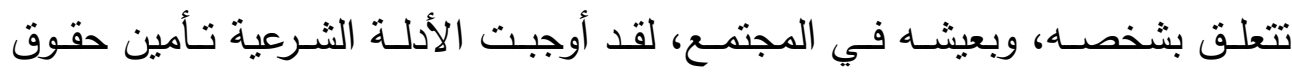

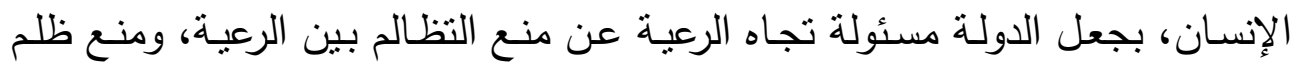

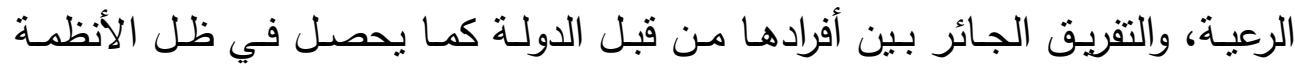
الوضعية، من ظلم الأغنياء للفقراء، أو البيض للمن للمنونين، أو الأكثرية للأقلية.

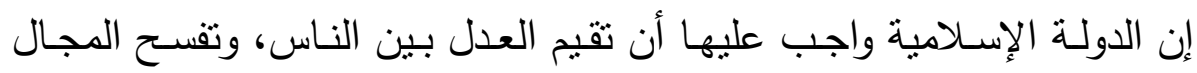

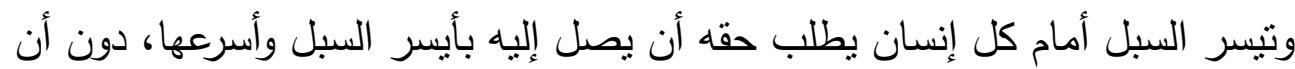

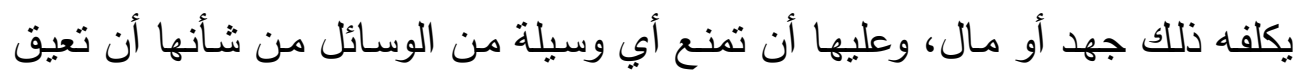

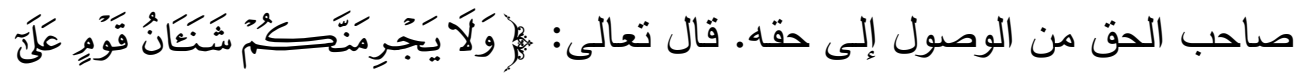

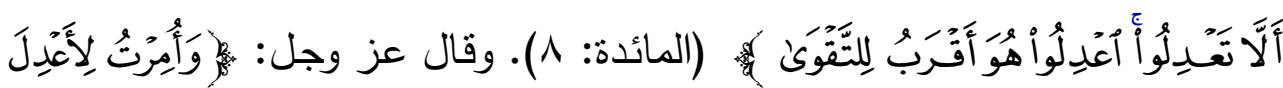

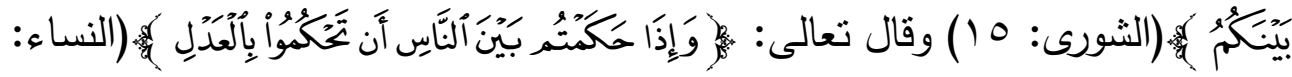

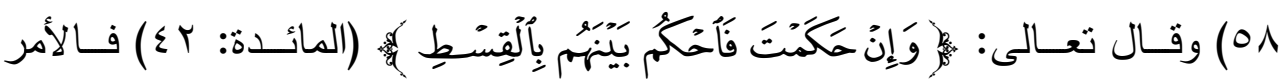

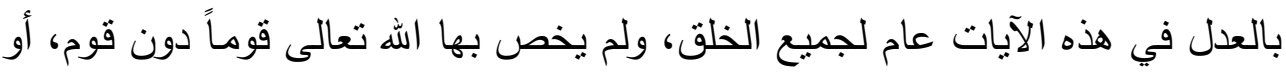

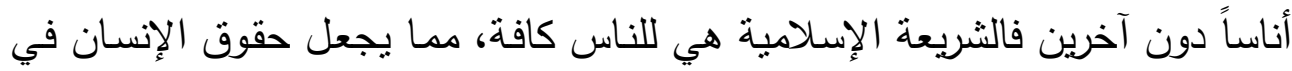


المجتمع الإسلامي حقوقاً شمولية لكل أفراده. قال سيد قطب عن القيادة الإسلامية: (فهي قيادة ذات سلطات تعلن العدل في لإني

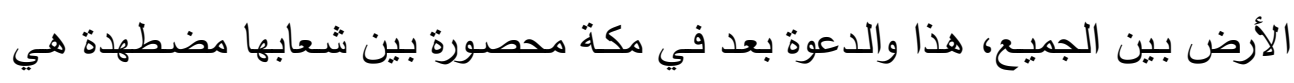

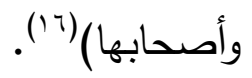

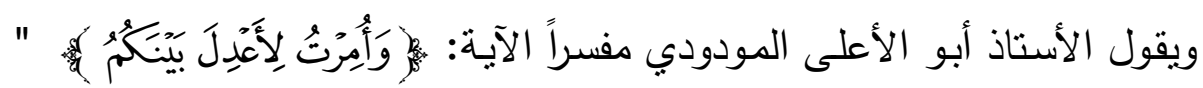

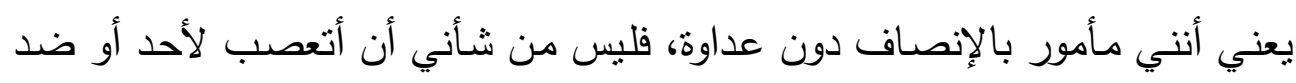

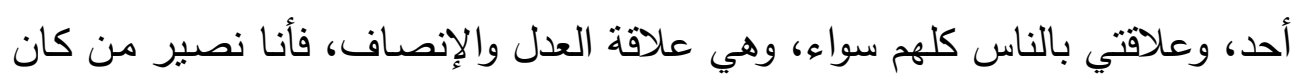
الحق في جانبه، وخصيم من كان الحق ضده، وليس في ديني أي امتيازات لأي فرد

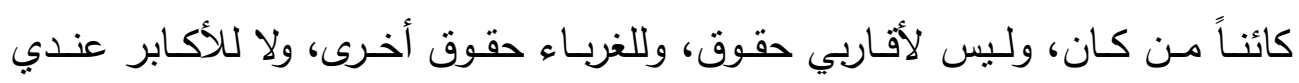

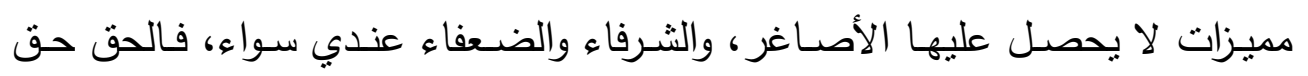

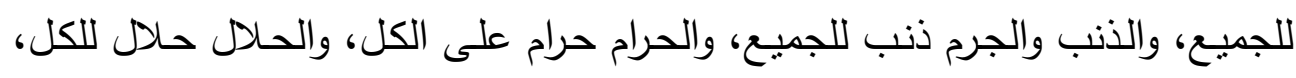

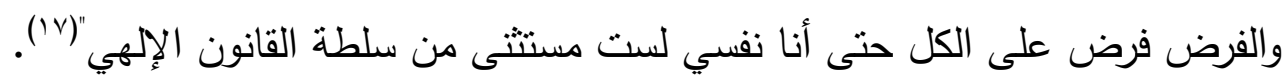

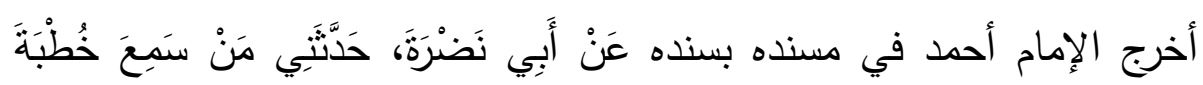

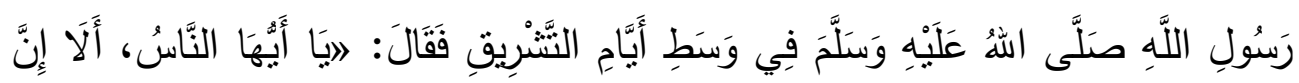

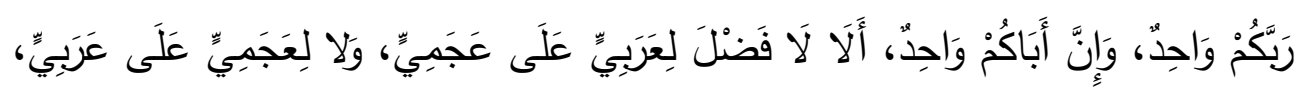

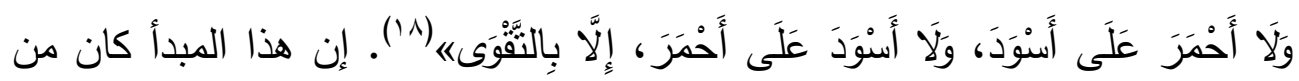
أهم المبادئ التي جذبت الكثير من الثعوب قديماً نحو الإسلام، فكان هذا الماند المبدأ مصدراً من مصادر القوة للمسلمين الأولين.

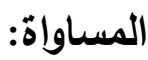

والإسلام نادى بالمساواة نظرياً، وطبقها أفراده عطلياً، وأقام عليها مجتمعاً حطم

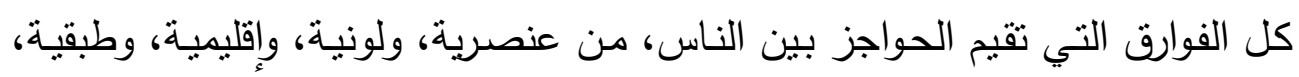
كما نرى ذلك واضحاً في صفحات الحضارة الإسلامية. 


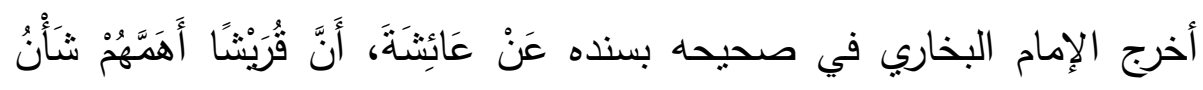

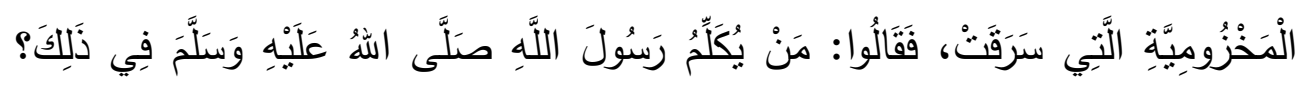

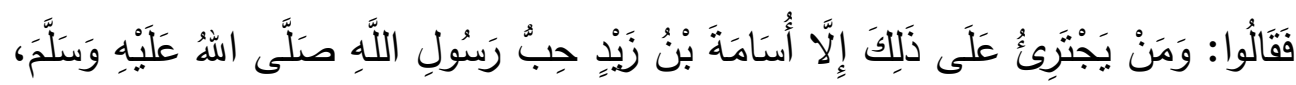

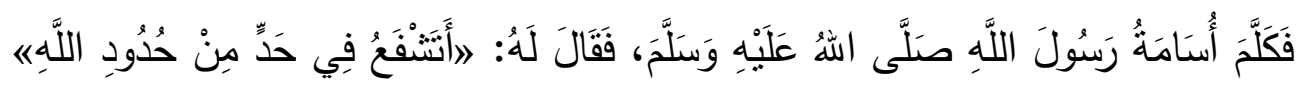

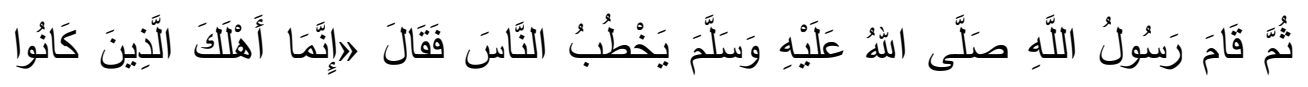

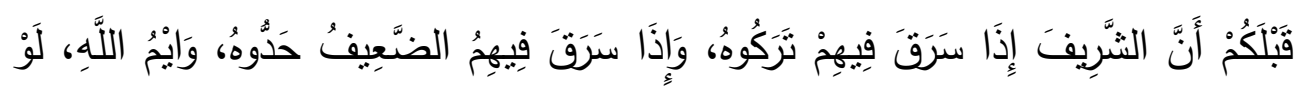

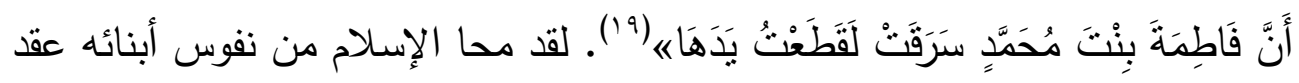
التمييز بين الأجناس والألوان والطبقات، التي سادت مجتمعات كثيرة، ولا زالت نسود

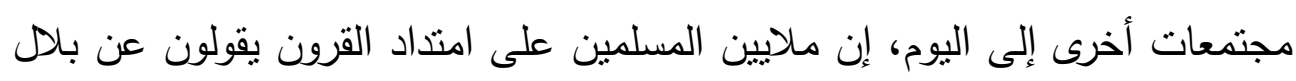

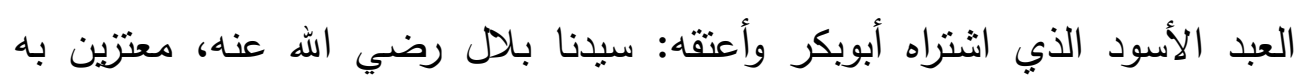

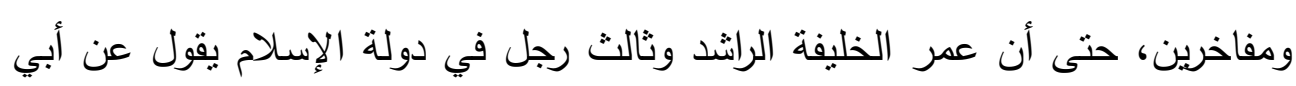
بكر : هو سيدنا وأعتق سيدنا ، أي: بلالاً.

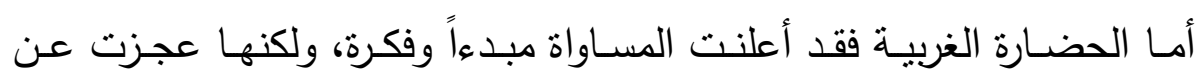

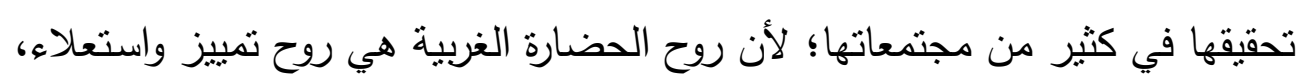

$$
\text { وليست روح إخاء ولا مساواة (عدل). }
$$




\section{المبحث الثاني}

\section{طرق جذب غير المسلمين الذين في داخل الدولة الإسلاهية إلى الإسلام}

وفيه ثمانية مطالب:

توطئة: لقد تمتع غير المسلمين في ظل الدولة الإسلامية بحقوق لم يكفلها أي نظام لغير رعاياه المخالفين له في دينه، وهذا بفضل الوصايا النبوية بالإحسان إلى أهل

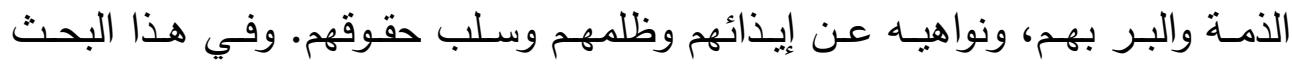
سنتعرف على الطرق التي تجذب غير المسلمين إلى الإسلام، وكيفية تعامل المسلمين مع أهل الكتاب داخل حدود الدولة الإسلامية. المطلب الأول: تقديم الإسلام للديانات السماوية الأخرى:

لقد قرر الإسـام أن محمداً

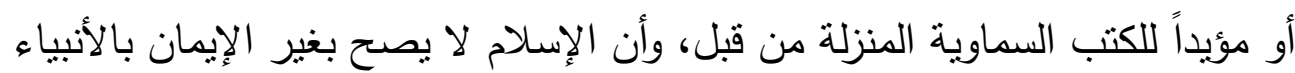

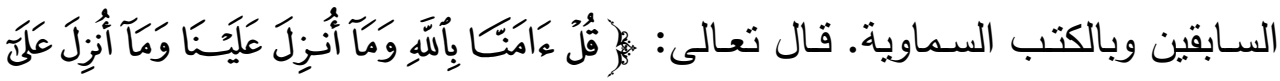

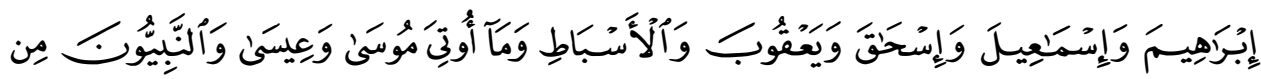

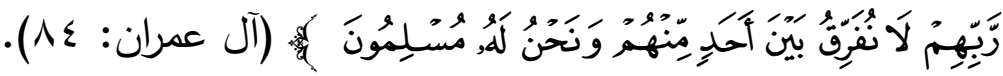

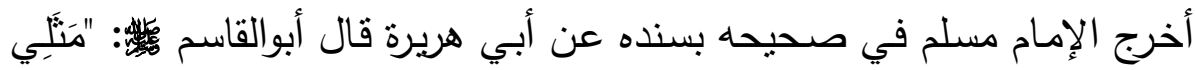

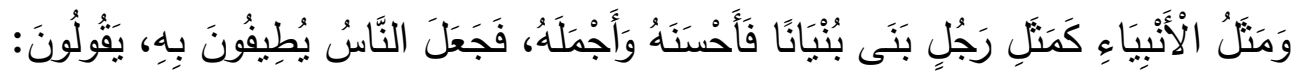

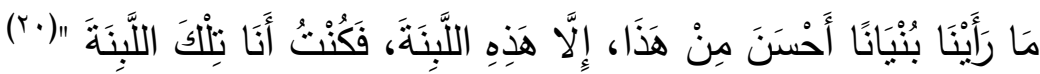

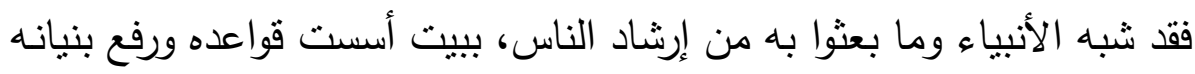

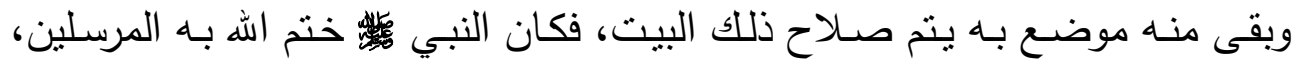

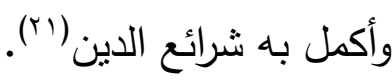
وأخرج الإمام البخاري في صحيحه بسنده عن ابن عباس رضي الله عنَّهما فَّالَ:

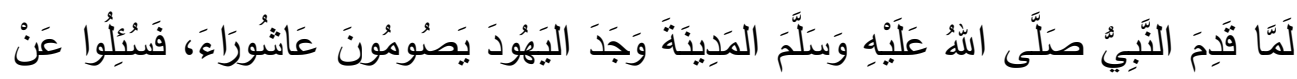

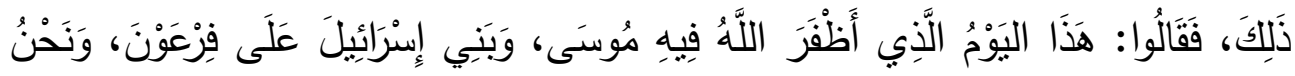




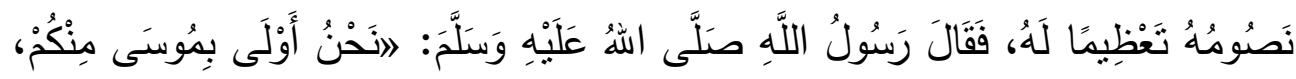

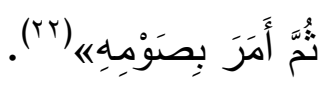
هذا في الوقت الذي لم يكن فيه موقف اليهود والنصارى إلا الإنكار، ولا

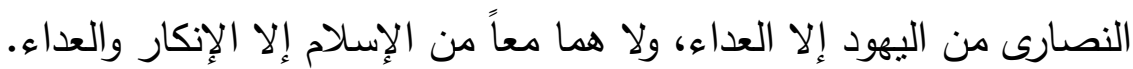

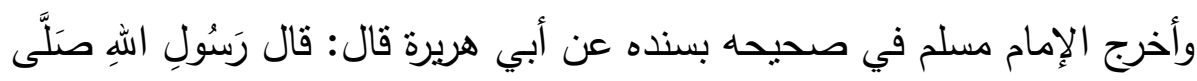

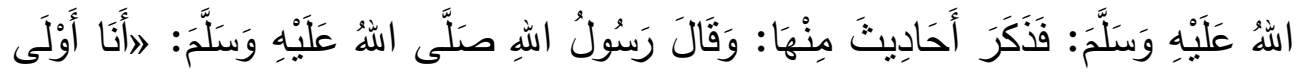

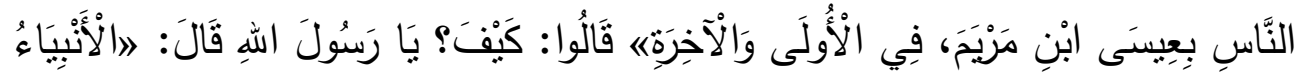

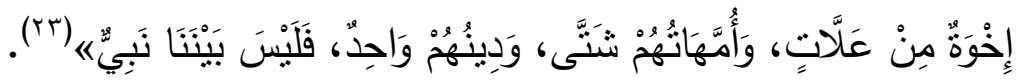

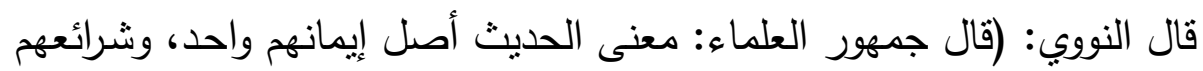

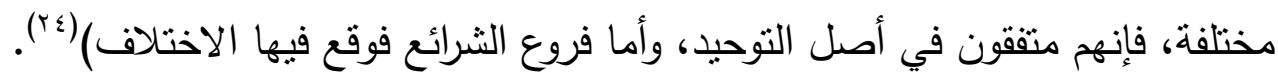
المطلب الثاني: العشرة الحسنة معهم: المانه لقد حرص الإسلام على المحافظة على العشرة الحسنة بين أبنائه وأهل الكتاب،

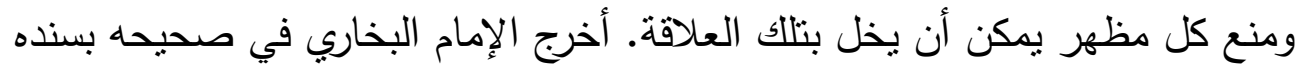

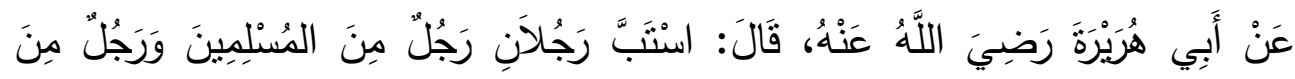

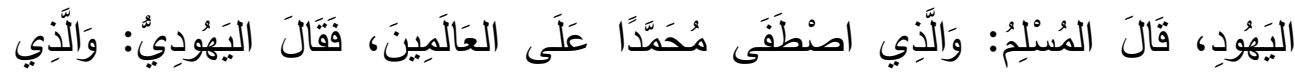

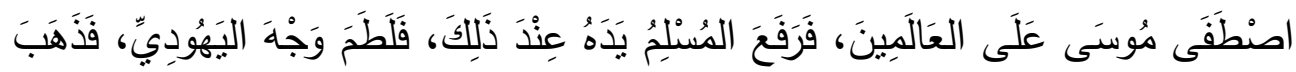

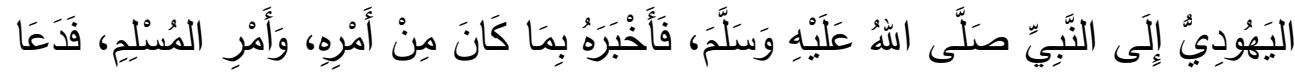

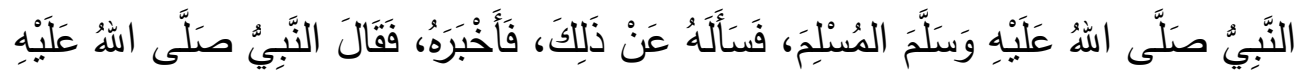

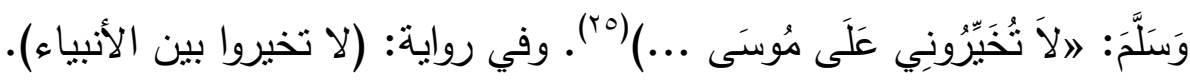
والمقصد من ذلك: النهي عن النظاهر بذلك بين ظهراني اليهود حرصاً على التى استبقاء حسن المعاثرة، وتجنباً لحوادث العصبية التي تفضي إلى الخصومة والتتازع،

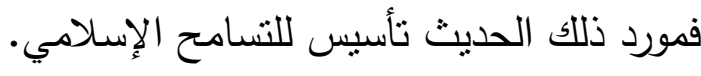
ومن العشرة الحسنة المحافظة على جيرتهر: فالإسلام حث على الإحسان إلى الجار وكف الأذى عنه ولو كان غير مسلم. 


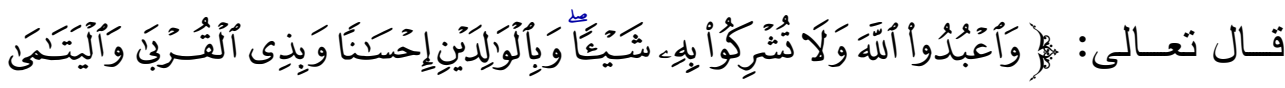

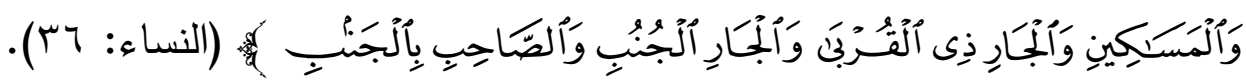

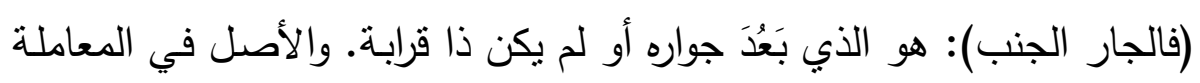

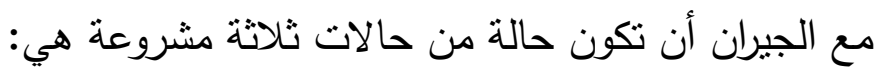

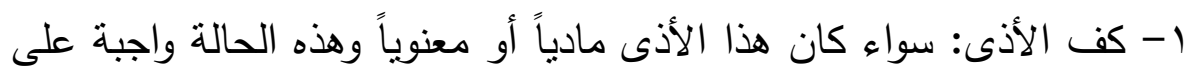

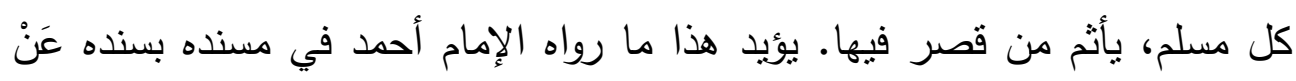

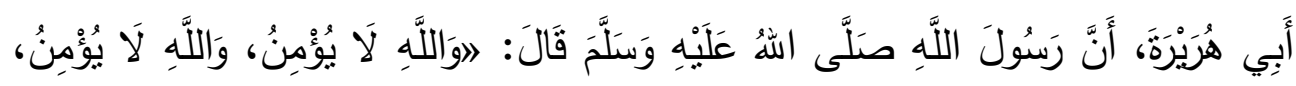

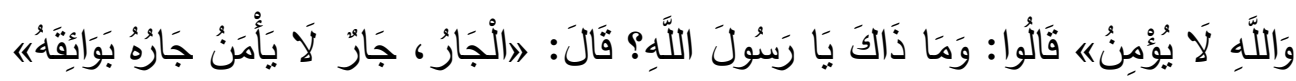

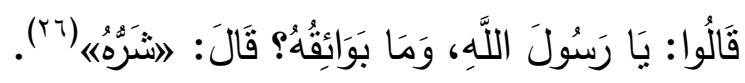

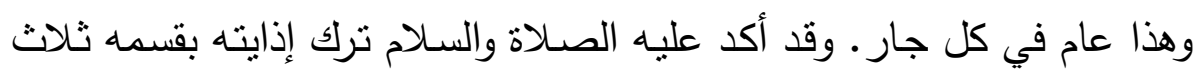

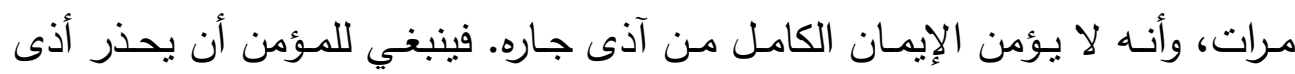
جاره، وينتهي عما نهى الله ورسوله عنه، ويرغب فيما رضياه وحضَّا العباد عليه.

ץ- إكـرام الجـار، وذللك بالتواصـل الاجتمـاعي معـه، ومشــاركته في أفراحسه

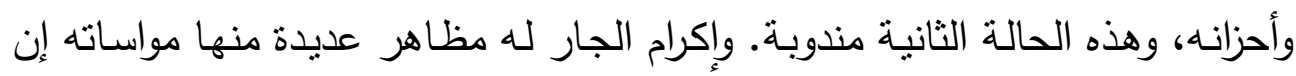

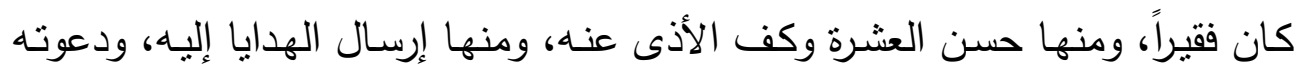
إلى الطعام، وزيارته وعيادته ونحو ذللك.

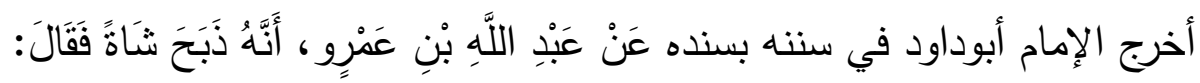

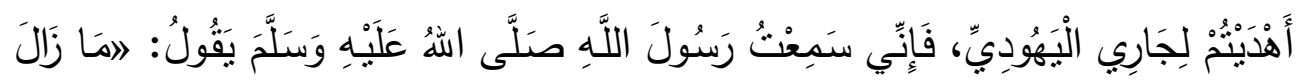

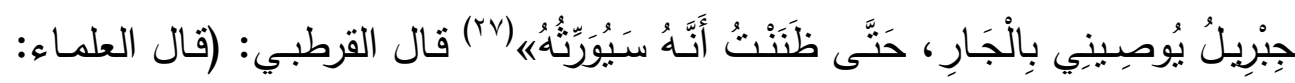
الأحاديث في إكرام الجار جاءت مطلقة غير مقيدة حتى الكافر ).

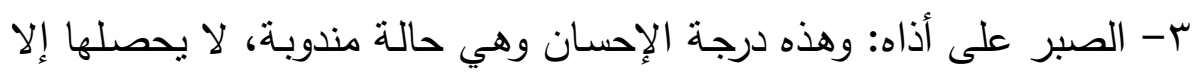


من قوي إيمانه.

ومن العشرة الحسنة التجاوز عن سيئاتهم:

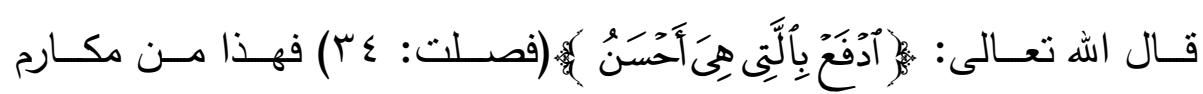

الأخلاق، التي أمر الله بها رسوله ومعناها: إذا أساء إليك أعداؤك، بالقول والفعل، فلا

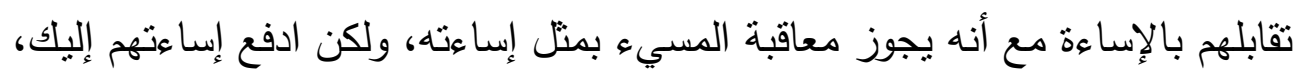

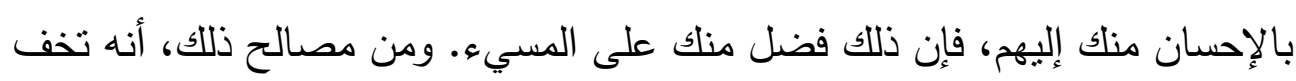

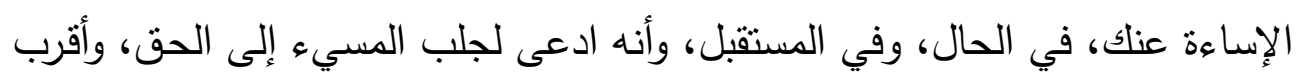

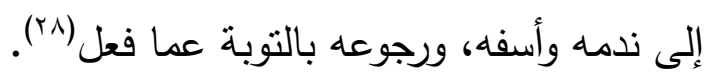

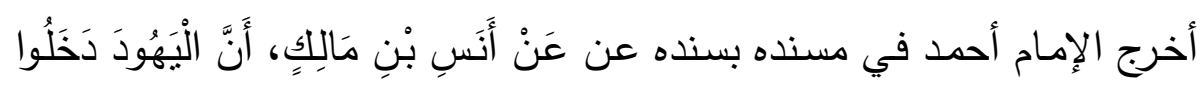

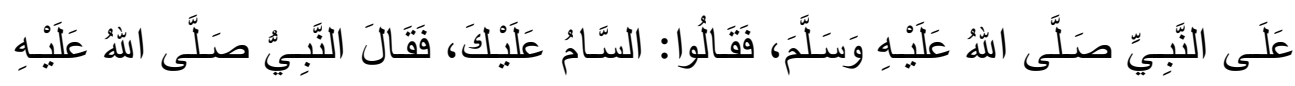

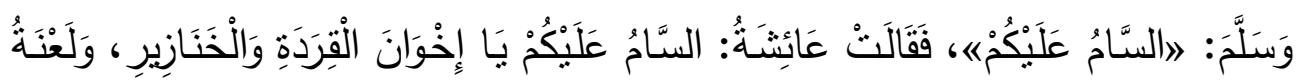

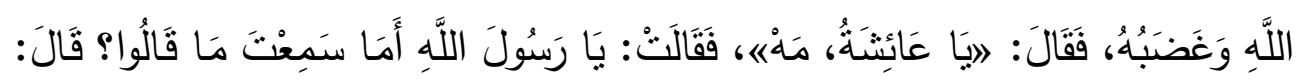

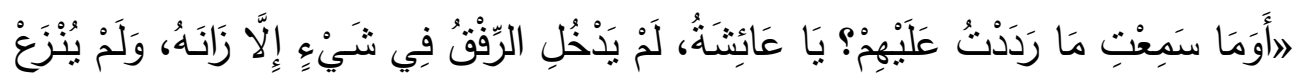

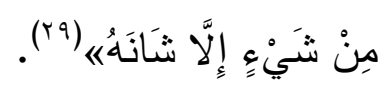

فهذا من مكارم أخلاق نبي الإسـام صلى اله عليه وسلم تجاه غير المسلمين،

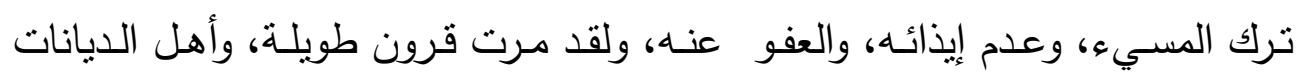

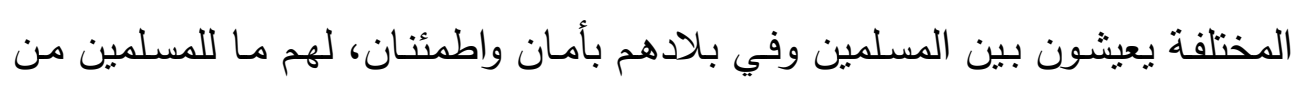

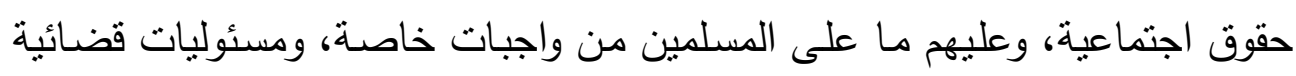
عامة. مما سبق يتبين لنا أن الإسلام حض على مكارم الأخلاق؛ لما يترتب عليها من المحبة وحسن العشرة ودفع الحاجة والمفسدة. وفي ظل هذه المعاني الإسـامية الكريمة، والهدى النبوي الثريف سار الخلفاء ولفاء الراثدون وولاة الأمور، فعاملوا أهل الذمة معاملة حسنة وأحاطوهم بالعناية والرعاية. 
فهذا الخليفة عمر بن الخطاب رضي اله عنه أصيب بضربة رجل من أهل الذمة وهو

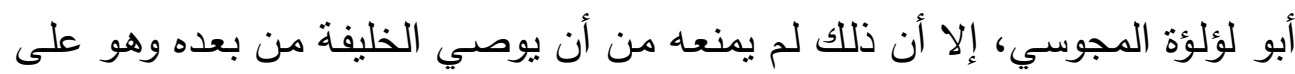

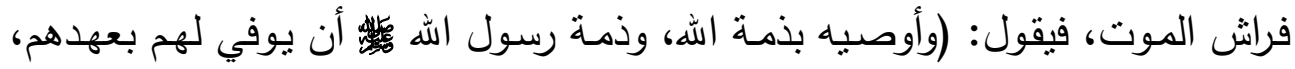

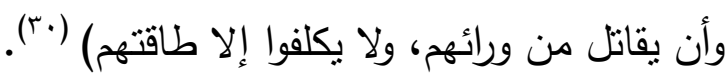

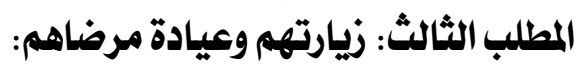
وتظهر هذه السماحة واضحة في معاملة النبي

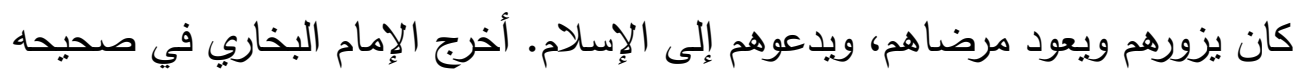

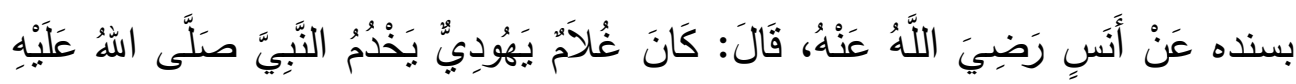

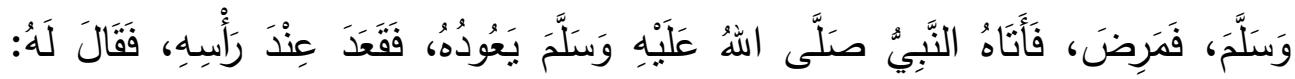

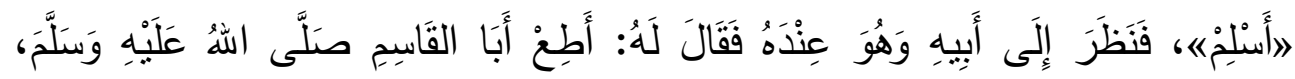

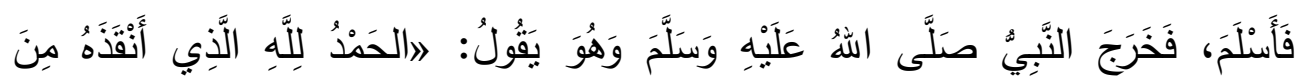

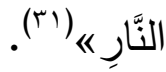

وإنما دعا النبي إس اليهودي الذي خدمه إلى الإسـام، لأن الله تعالى أخذ عليه

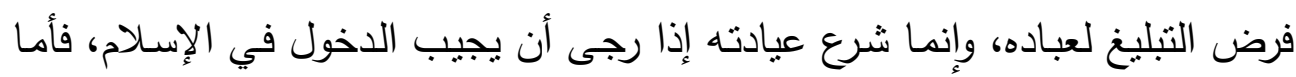

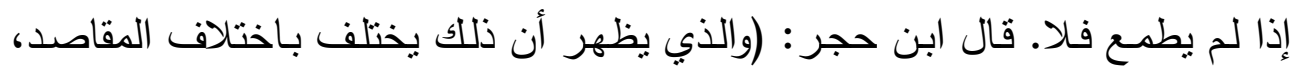
فقد يقع بعيادته مصلحة أخرى) (بr). وكانت يهودية تزور عائشة وتتحدثان. أخرج الإمام البخاري في صحيحه بسنده

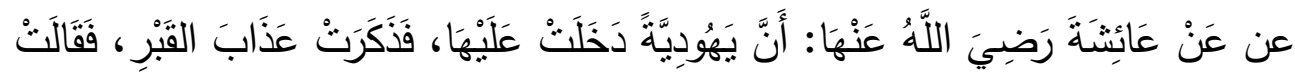

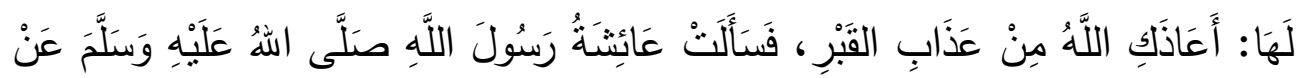

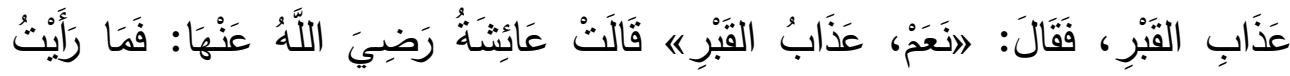

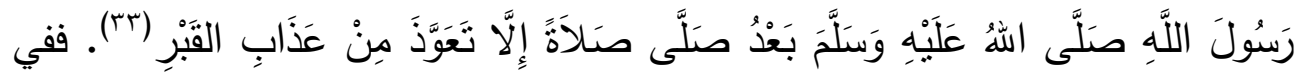
الزيارة تزول الحواجز ، ويتعرف كل منهما على الآخر، وقد ترقق القلب، وتوجد التواد الذي يكون وسيلة طيبة للدعوة إلى الإسلام. المطلب الرابع: مؤاكلة أهل الكتاب والأكل من ذبائحهم: 
أباح الإسلام الأكل من ذبائح أهل الكتاب - اليهود والنصارى- قال اله تعالى:

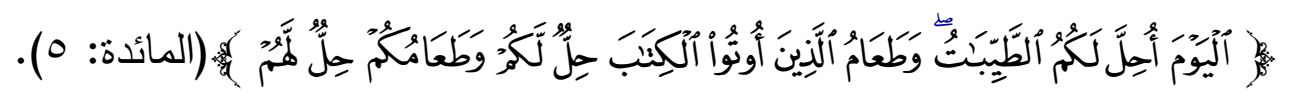

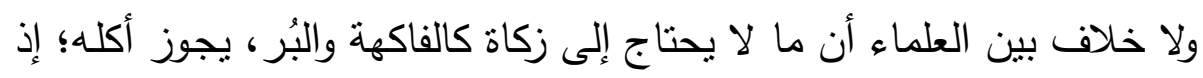

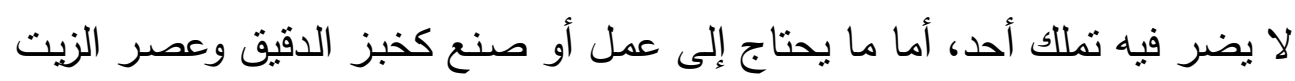
ونحوه، والتذكية التي تحتاج إلى الدين والنية، فرخص الله تعالى فيه، تألفاً لأهل الذمة ألماء وترغيباً لهم في الإسلام.

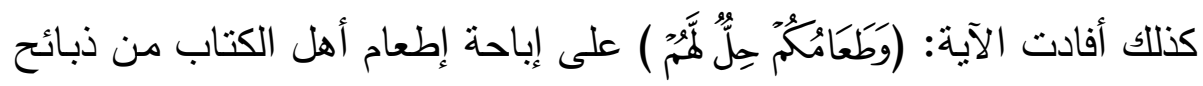

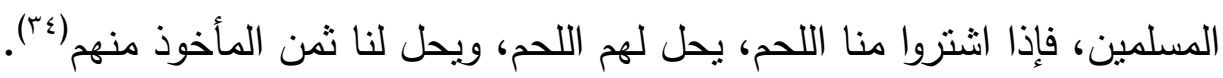

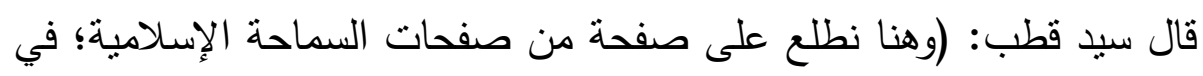

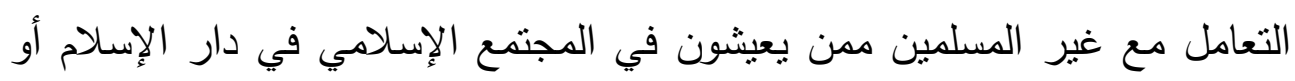

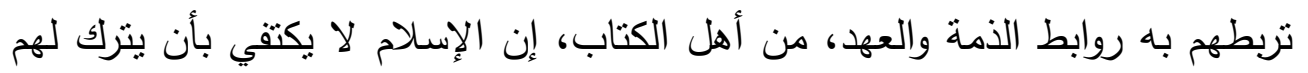

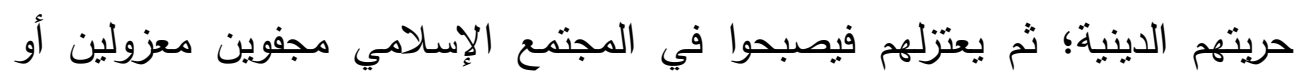

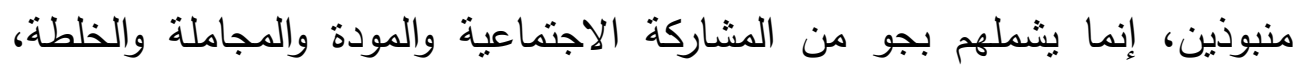

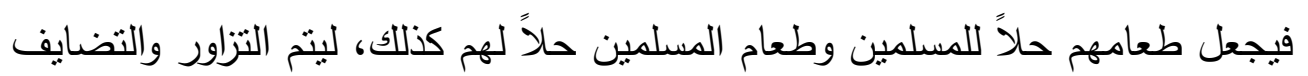
والمؤاكلة والمشاربة وليظل المجتمع كله في ظل المعام المودة والسماحة) (ro). الطلب الخامس: مصاهرة أهل الكتاب وتزوج نسائهم المحصنات العفيفات:

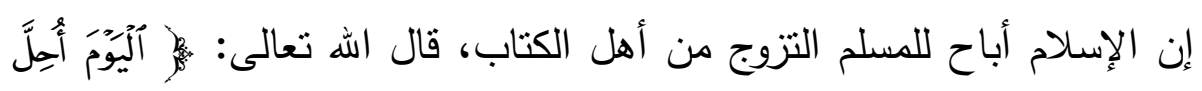

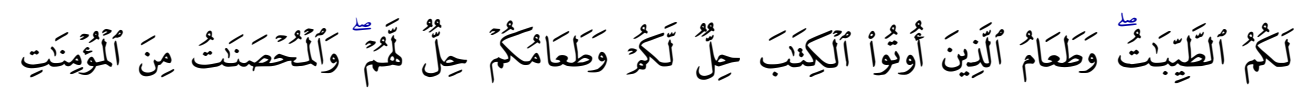

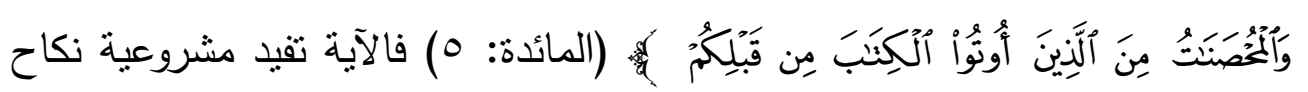

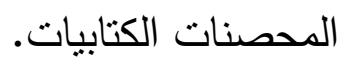

قال سيد قطب: (وكذلك يجعل العفيفات من نسائه وهن المحصنات بمعنى

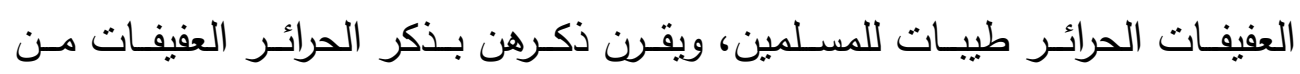

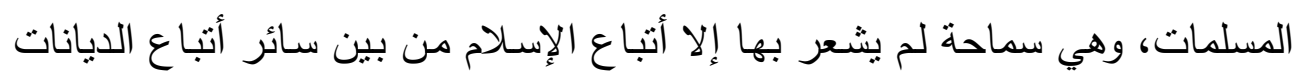


والنحل، فإن الكاثوليكي المسيحي ليتحرج من نكاح الأرثوذكسية، أو البرونستانتية، أو

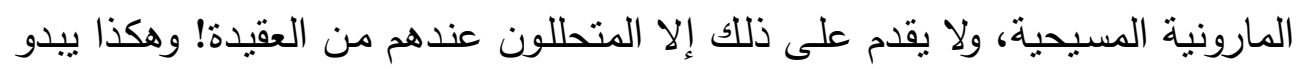

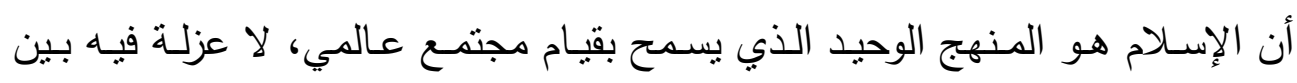

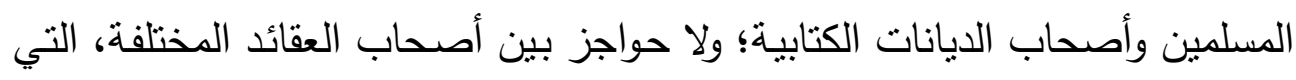
تظلها راية المجتمع الإسلامي. فيما يختص بالعشرة والسلوك)(بَّات.

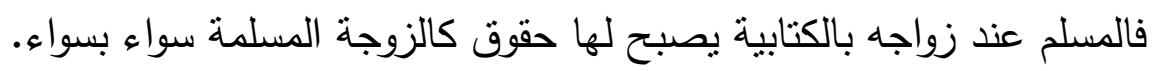

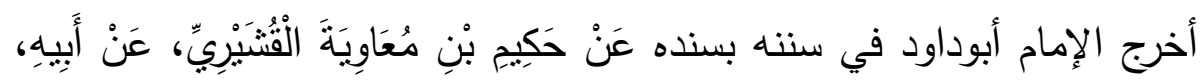

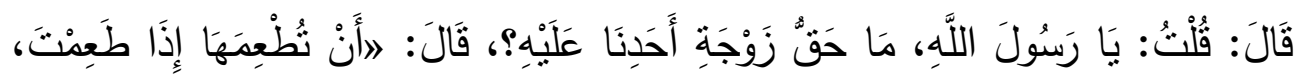

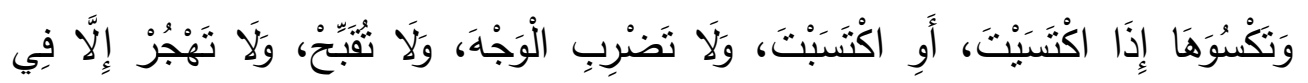

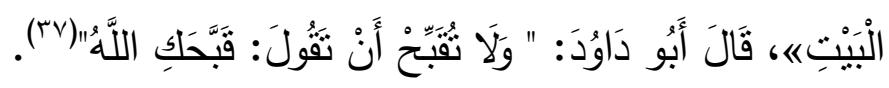

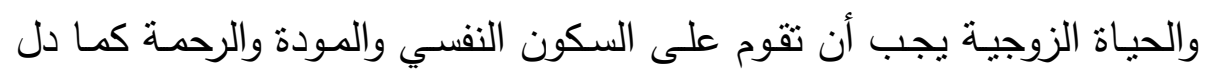

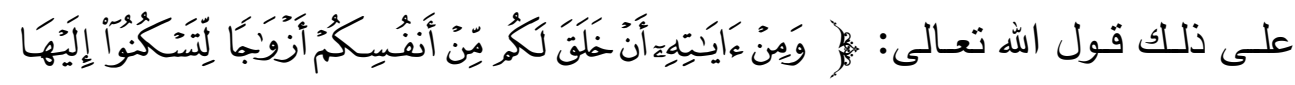

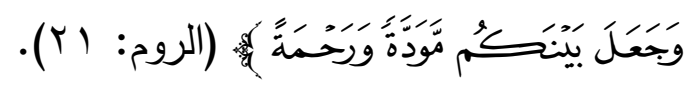

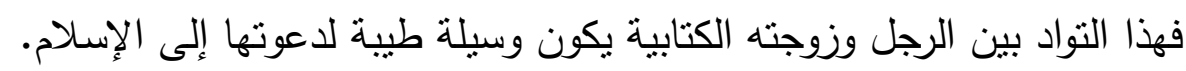
الططلب السادس: مساعدة الدولة المسلمة للمحتاجين من أهل الكتاب:

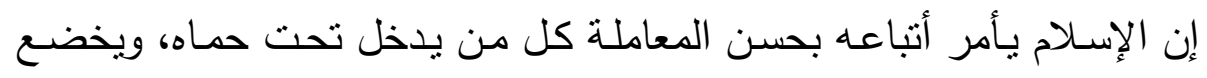

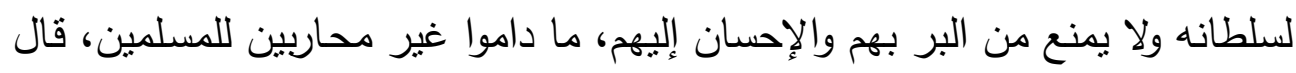

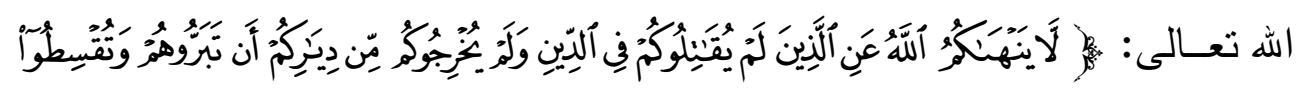

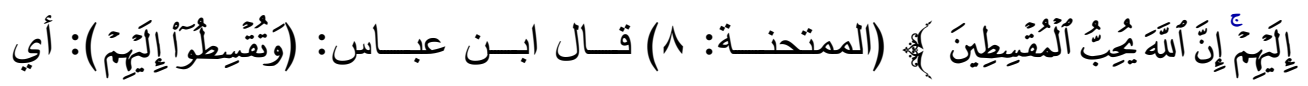
بالصلة وغيرها.

قال الطبري: (وأولى الأقوال في ذلك بالصواب قول من قال: عني بذللك: لا

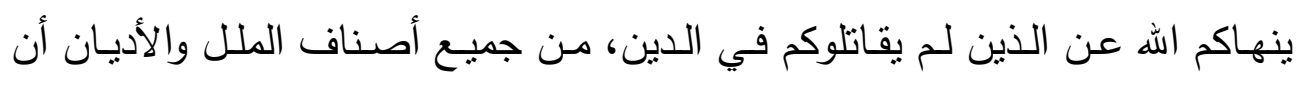

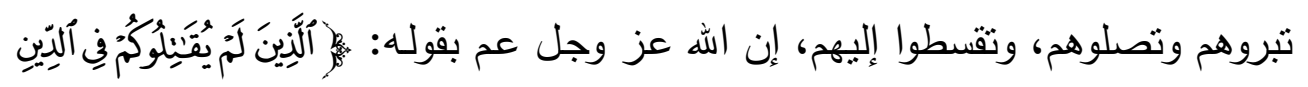




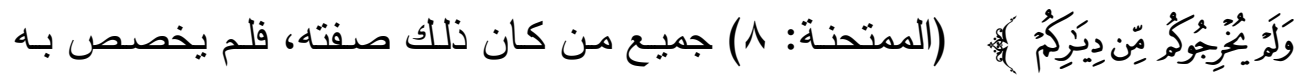

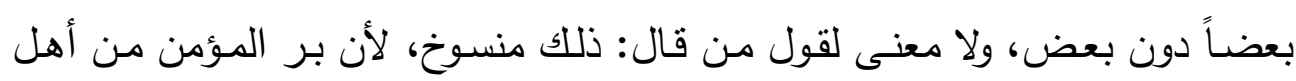

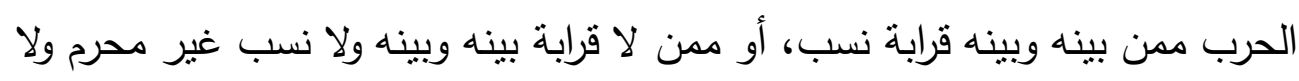

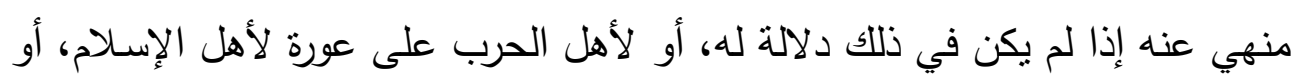

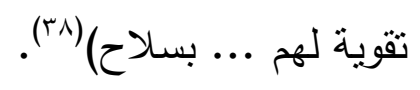

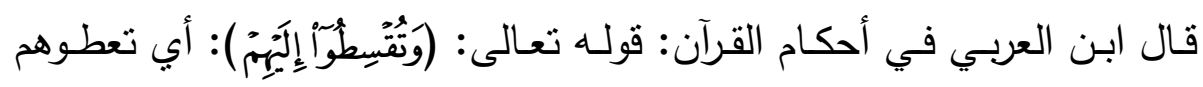

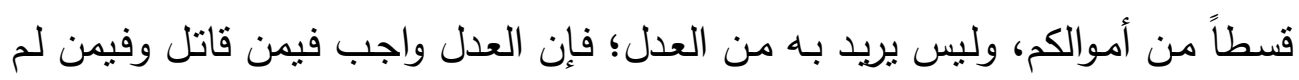

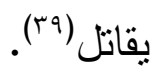

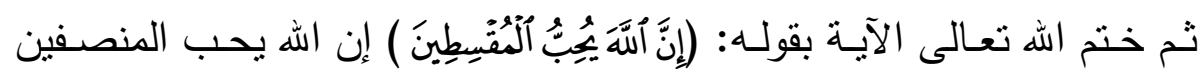

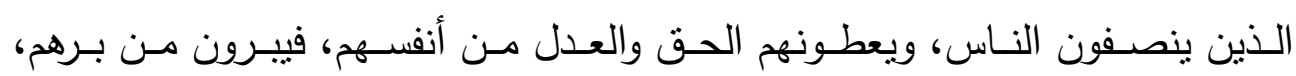
ويحسنون إلى من أحسن إليهم. فالإسلام يأمر أهله بحسن معاملة كل من يدخل تحت حماه، ويخضع لسلطانه

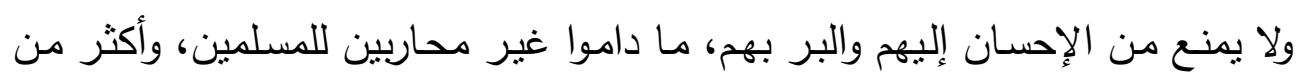

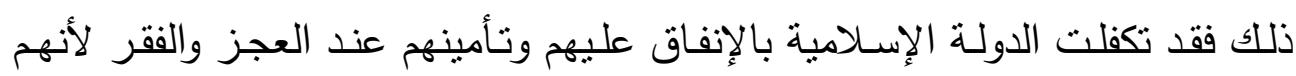
رعاياها، ومن حقهم عليها أن ترعاهم.

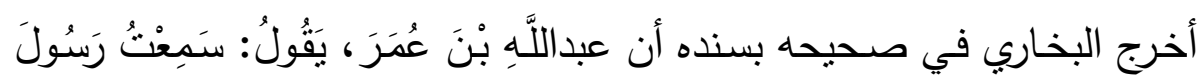

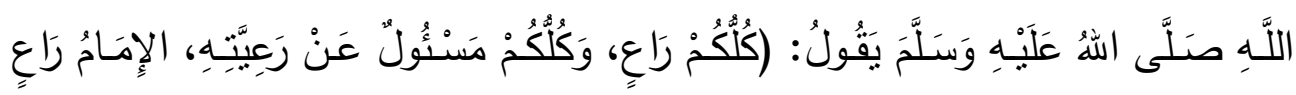

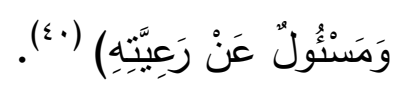
ولقد بلغ عمر بن الخطاب القمة في السماحة والرحمة مع أهل الذمة حتى أنفق على مساكينهم من بيت المال، فقد مر عمر بن الخطاب رضي الله عنه بباب قوم

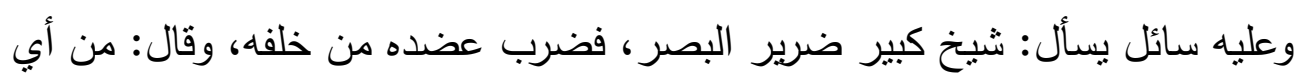
أهل الكتاب أنت؟ فقال: يهودي. قال: فيال: فما ألجأك إلى ما أرى؟ قالى فال: أسأل الجزية والحاجة والسن. قال: فأخذ عمر بيده، وذهب به إلى منزله فرضخ لهاله له بشيء من البه 
المنزل. ثم أرسل إلى خازن بيت المال، فقال: انظر هذا وضرباه؛ فواله ما أنصفناه أن

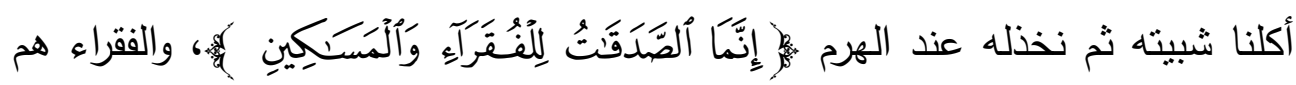
المسلمون وهذا من المساكين من أهل الكتاب، ووضع عنه الجزية وعن ضربائه (1). المطلب السابع: مناقشتهم بالحسنى:

النقاش والحوار مـع غير المسلمين هو من السماحة الإسلامية العظيمة، وإنما

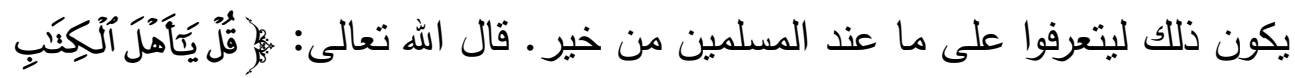

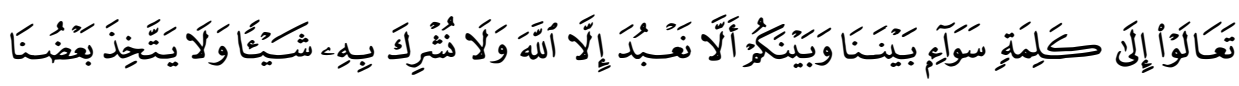

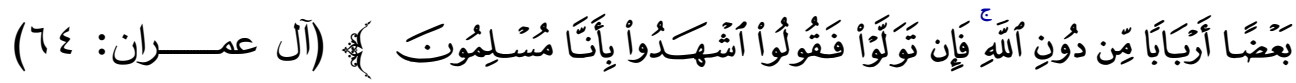

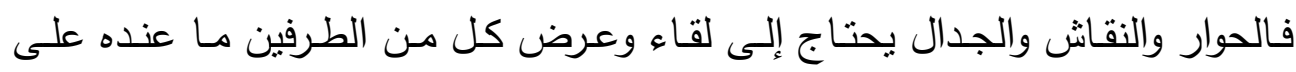
الآخر ، ويكون بالأسلوب الحسن وبالحكمة والموعظة الحسنة، فذلك أدعى عند العقلاء

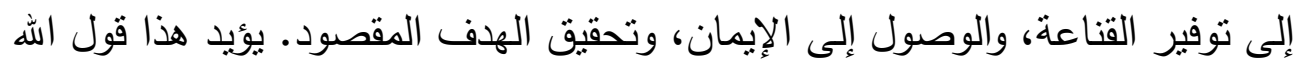

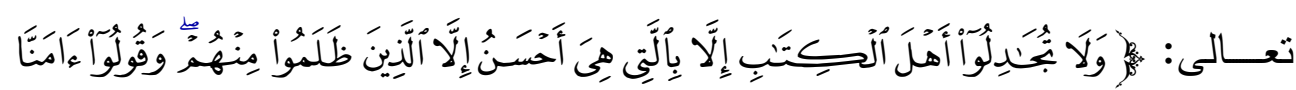

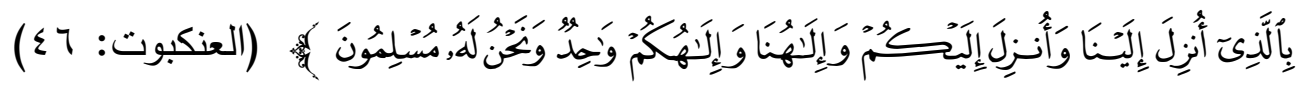

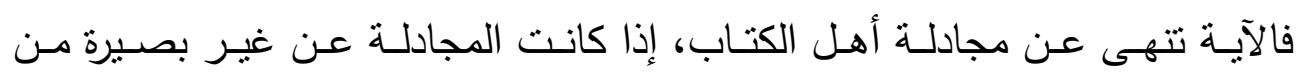

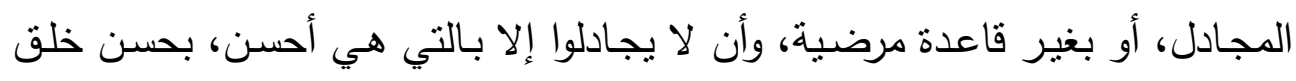

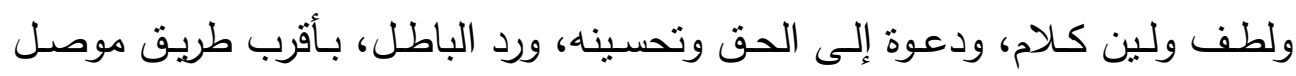

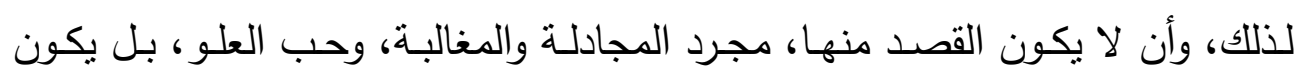

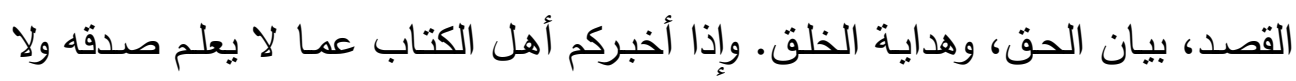

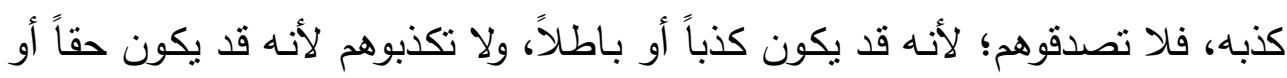

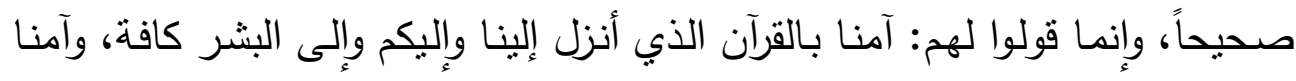

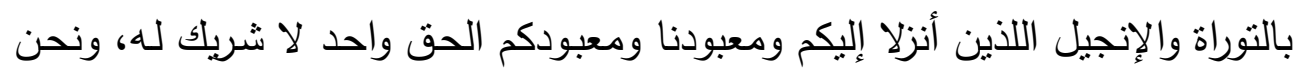
له خاضعون مطيعون أمره ونهيه. أخرج الإمام البخاري في صحيحه بسنده عَنْ أَبِي هُرَيْرََ رَضِيَ اللَّهُ عَنْهُ، قَالَ: 


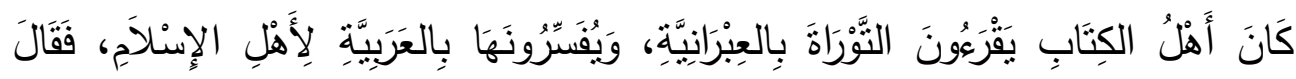

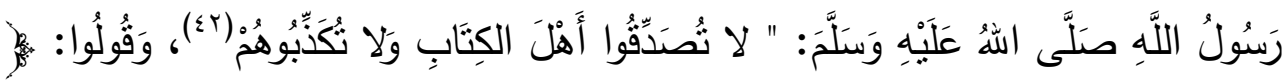

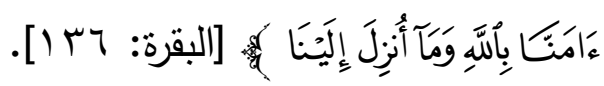

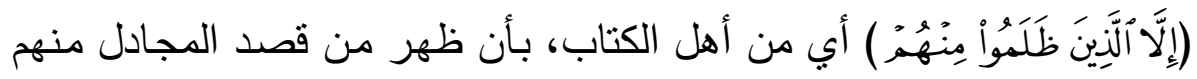

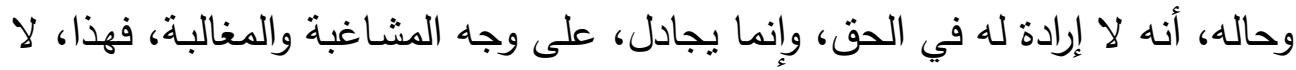
فائدة في جداله، لأن المقصود منها ضائع.

وأرى أن على الناشطين في حقل الدعوة الإسـامية أن يجتهدوا في تعريف الغرب بالإسلام، وأن يرفعوا من أمام الغربيين حواجز الخوف من الإسـام، ويطلعونهم

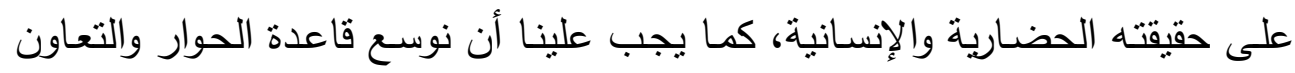

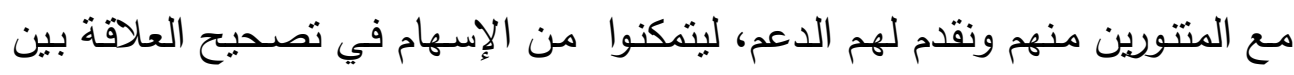

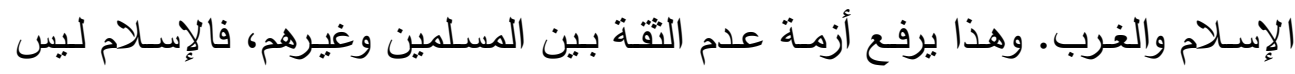

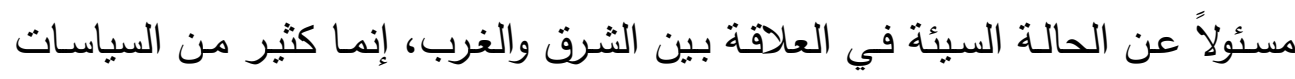
الغربية هي السبب في ذللك.

\section{المطلب الثامن: إنزالهم منازلهم وإظهار الرفق واللين معهم:}

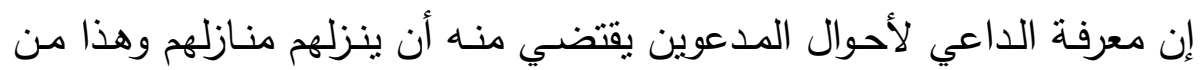

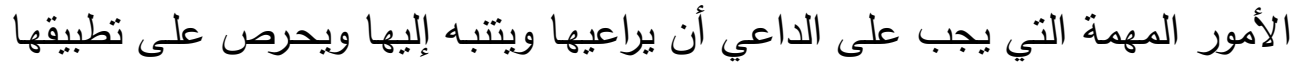

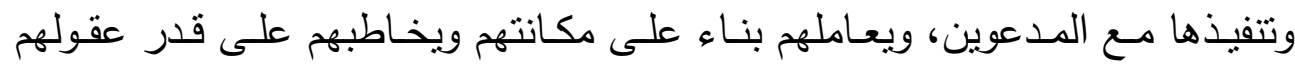

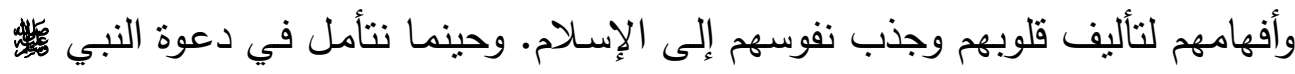
نجد أنه كان يراعي أحوال الدعوين وينزلهم منازلهم.

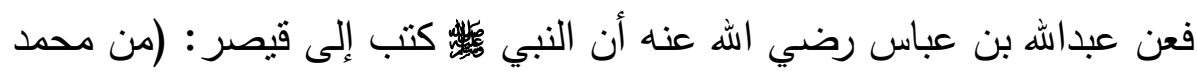

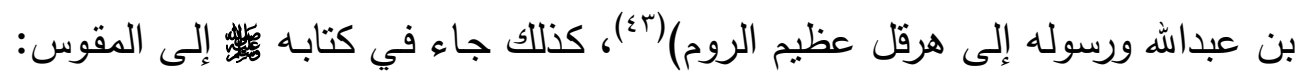

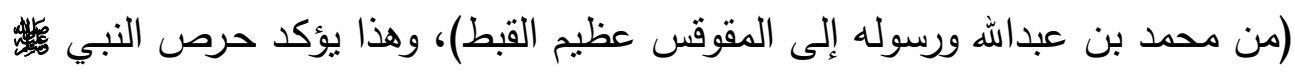


على إنزال الناس منازلهم لترغيبهم ولجذبهم إلى الدين الإسلامي.

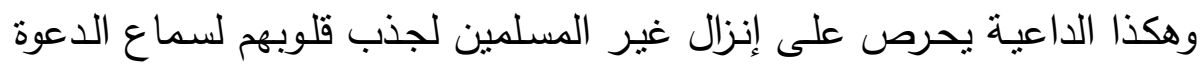

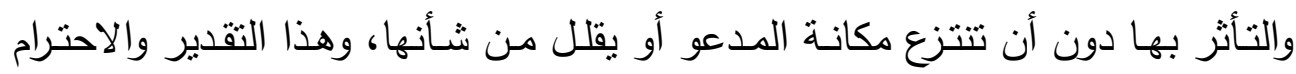
لحال المدعو من شأنه أن يدعوه للتفكير في هذا الدين الذي يعطي للإنسان قدره ويعلي منزلته.

ومما يجدر التتبيه لـه عند دعوة غير المسلمين، ضرورة عدم التعرض لدينهم

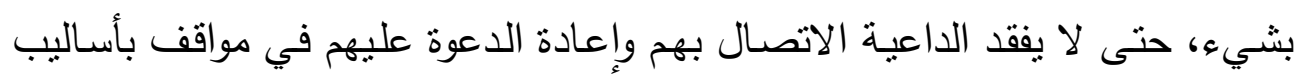

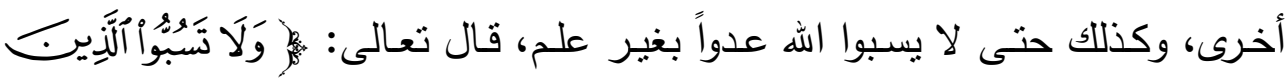

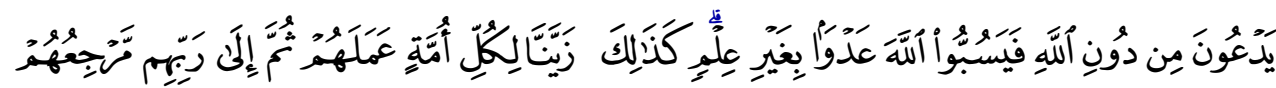

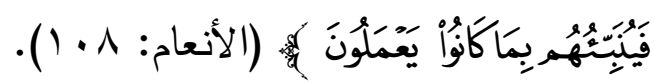

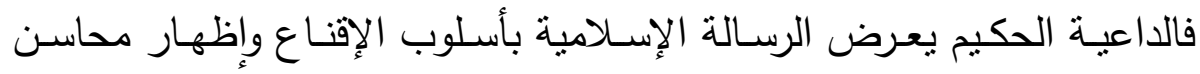

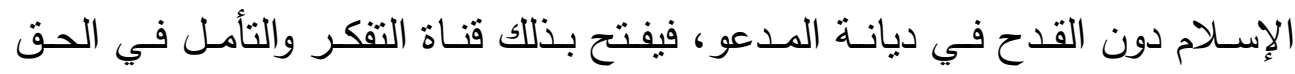

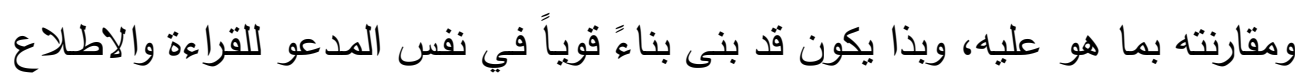
عن قرب في هذا الدين الجديد الذي عرضه ولئه الداعية.

والداعية إلى الله تعالى عليه أن براعي الرفق واللين في دعوة غير المسلمين

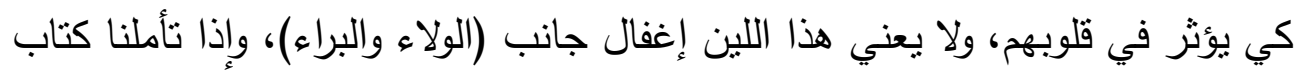

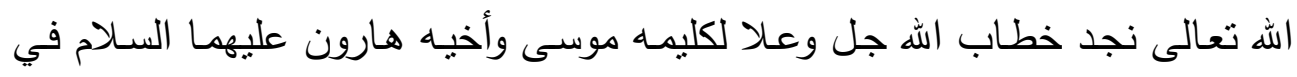

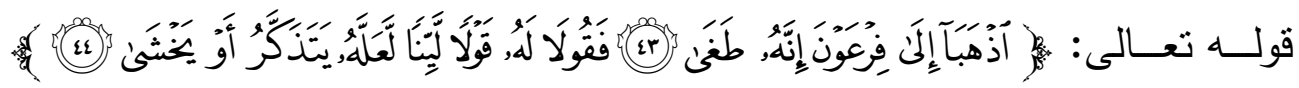

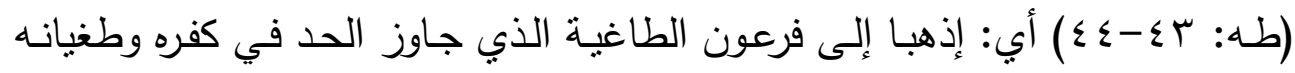

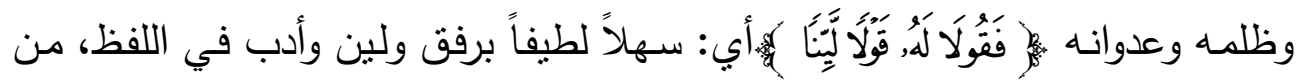

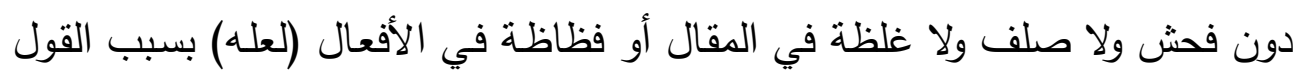


اللين (يتذكر ) ما ينفعه فيأتنه (أو يخشى) ما يضره فيتركه، فإن القول اللين داع لذلك

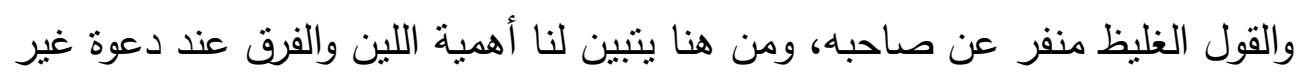

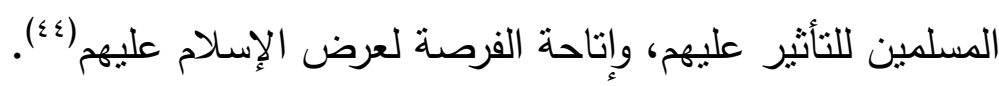




\section{المبحث الثالث}

\section{طرق جذب غير المسلمين الذين خارج الدولة الإسلاهية إلى الإسلام}

وفيه ثمانية مطالب:

توطئة: إن دعوة غير المسلمين إلى الإسلام لا تكون إلا بالاختلاط بهم، وعلى الرغم

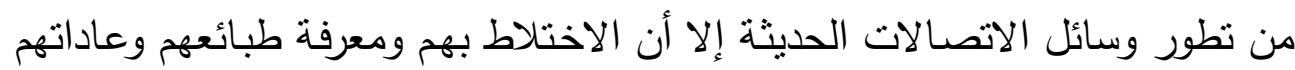
وثقافتهم يمهد الطريق إلى دعوتهم، والاختلاط بهم يحتم إحسان القول لهم، والإحسان إلى أسراهم، والحرية الدينية لهم، والتعامل معهم أخذاً وعطاءً، والوفاء بالعهذ معهر.

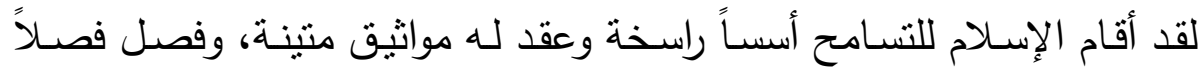

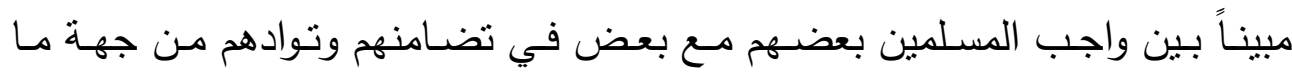

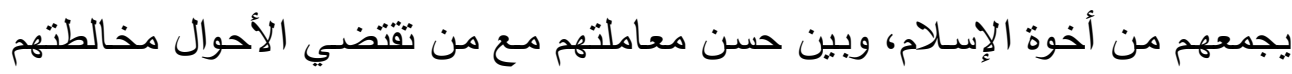

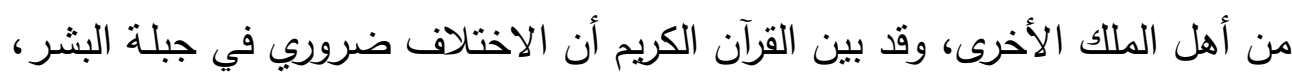

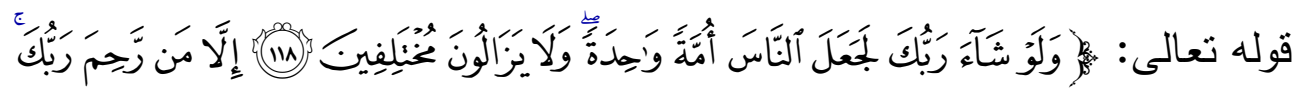

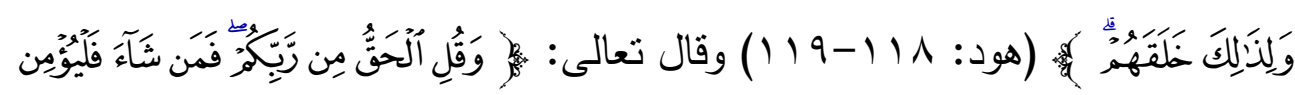

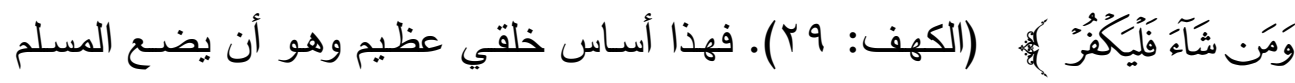

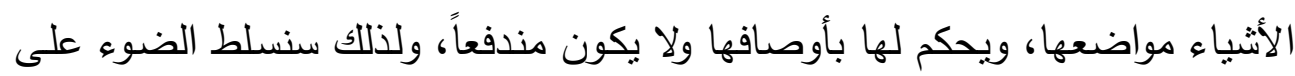
بعض الطرق التي تجذب غير المسلمين إلى الإسلام خارج حدود الدولة الإسلامية في

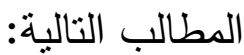

\section{المطلب الأول: الأسلوب الحسن في نطاق الكتابة والخطابة والتحدث والنقاش:}

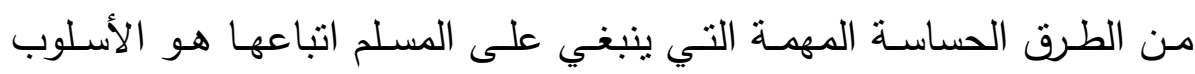

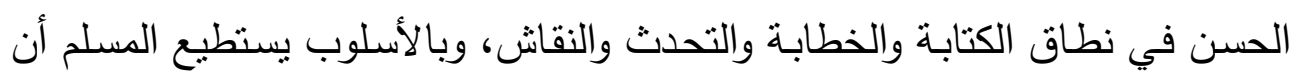
يصيب الهدف ويبلغ القصد بأقل التكاليف وأيسرها.

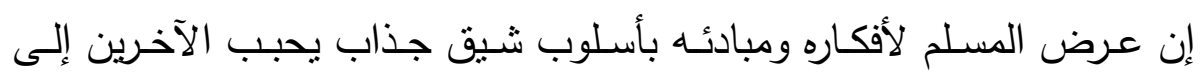

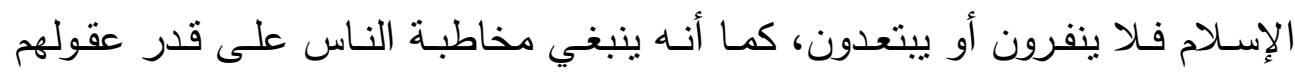


ومـداركهم، فـلا يخاطب العمـال الكـادحين بأسـلوب الفلاسفة أصـحاب المنطق، ولا يناقش الملاحدة الماديين بلسان عاطفي خال من الحجة والبرهان. والنفوس جبلت على حب من أحسن إليها بل وقد تدفعها القسوة والثدة أحياناً إلى المكابرة والإصرار والنفور فتأخذها العزة بالإثم، وليس معنى اللين المداهنة والرياء والنفاق، وإنما اللين ببذل النصح وإسداء المعروف بأسلوب دمث مؤثر يفتح القلوب

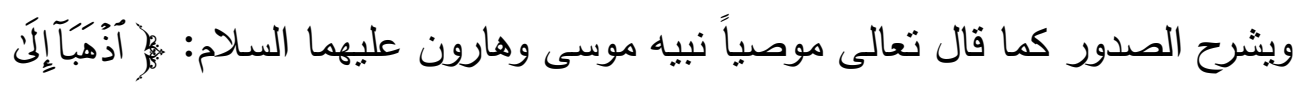

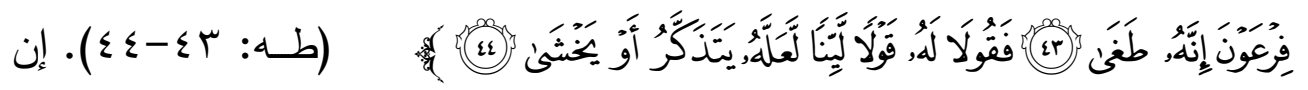

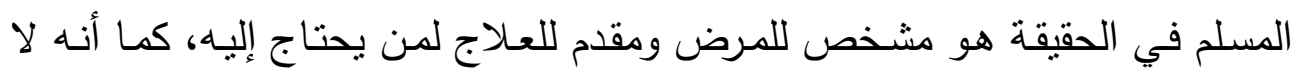

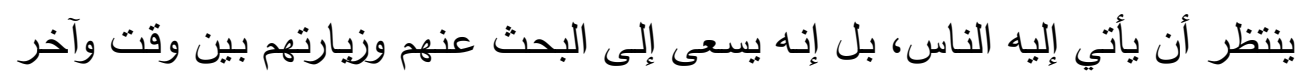
وفي فترات مناسبة لهم ودعوتهم في مختلف المناسبات. المطلب الثاني: إحسان القول لهم ودعوتهم إلى الإسلام: وإذا عرضنا تسامح الإسلام مع المخالفين في الدين رأينا تسامحاً كاملاً واضحاً

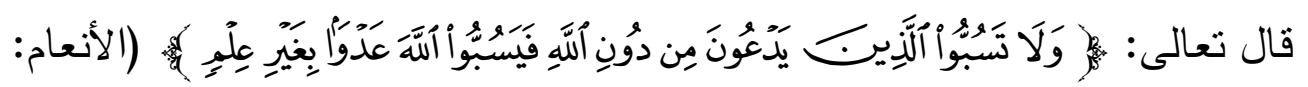

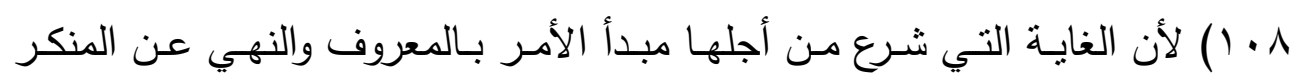
إثاعة الحق في المجتمع وإزالة الباطل عنه بقدر الإمكان، وذللك عن طريق النصيحة

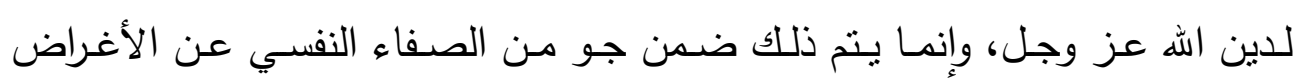

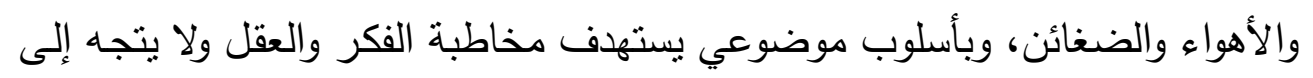

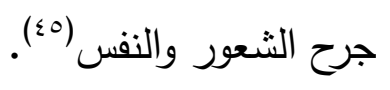
ولقد دعا الله تعالى عباده المؤمنين إلى القول الحسن مع الناس جميعاً، لأنه

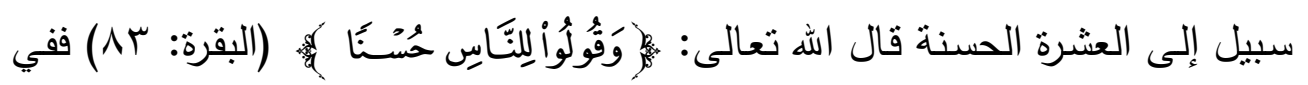
هذه الآيـة أمر الله تعـالى بالإحسـان إلى النـاس عموماً، ومـن القول الحسـن أمرهم

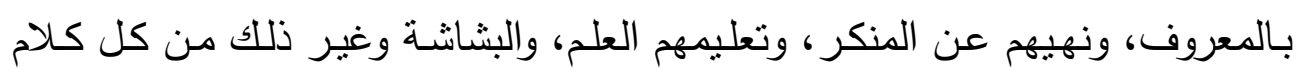
طيب. 
أخرج الإمام مسلم في صحيحه بسنده عن عبدالله بن عمرو بن العاص قال:

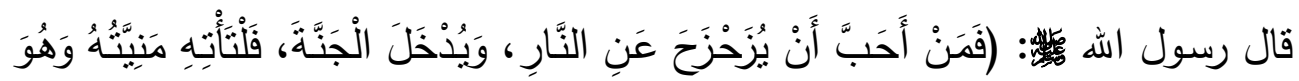

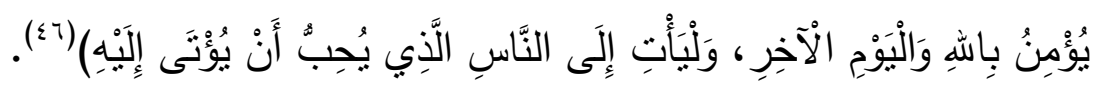

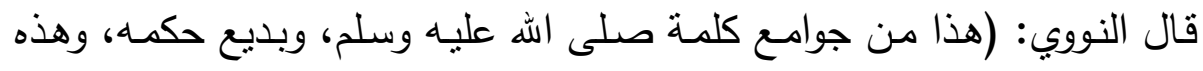

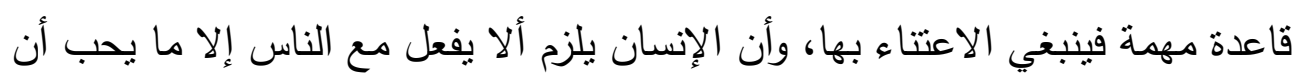

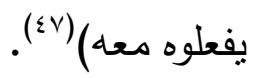

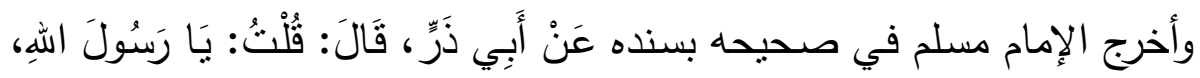

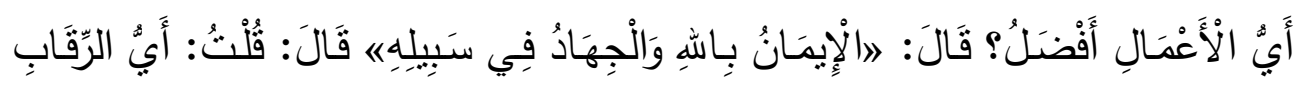

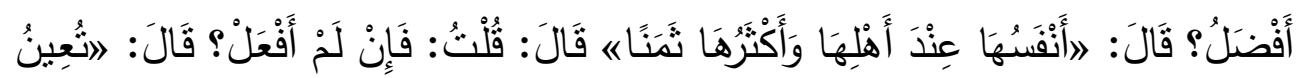

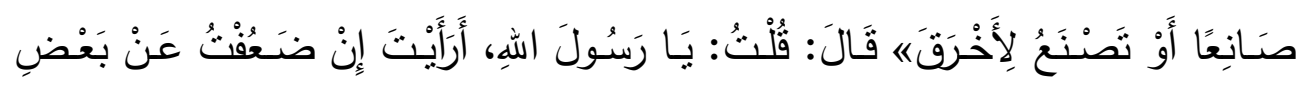

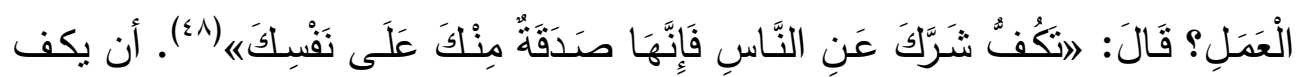

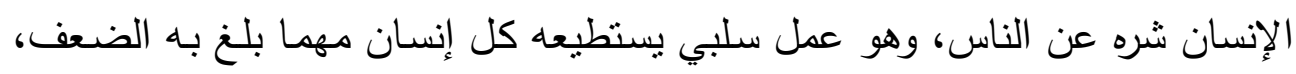

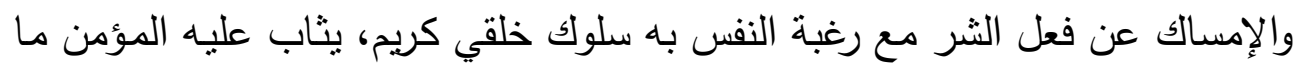
ابتغى به وجه الله.

ومن واجب المسلم دعوة الناس جميعاً إلى الإسلام. أخرج الإمام البخاري في

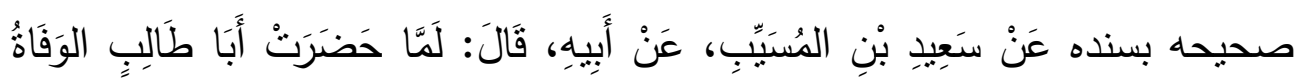

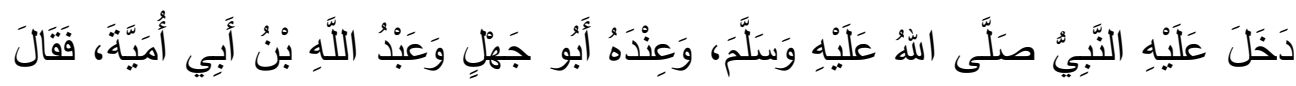

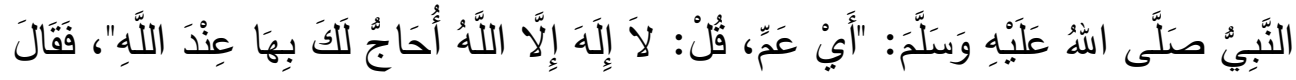

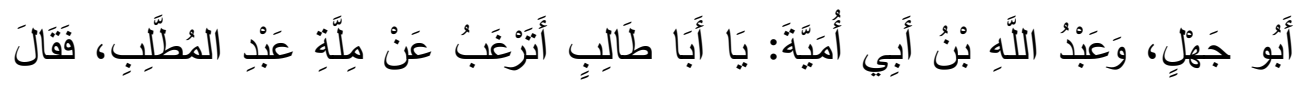

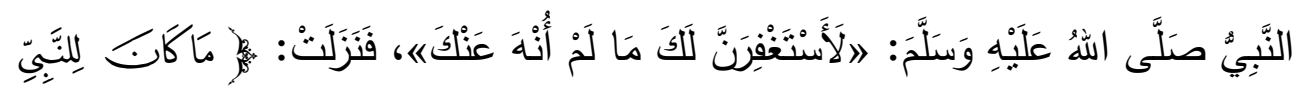

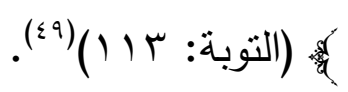

وإنما دعا النبي

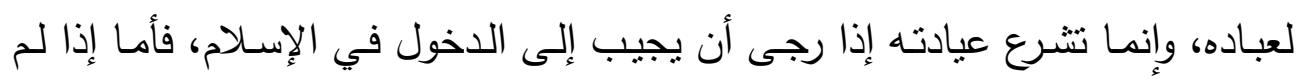


يطمع فلا. قال ابن حجر: (والذي يظهر أن ذلك يختلف باختلاف المقاصد، فقد يقع

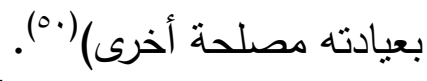

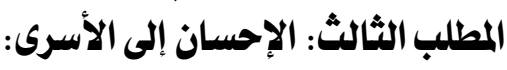

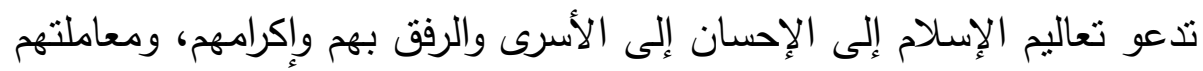

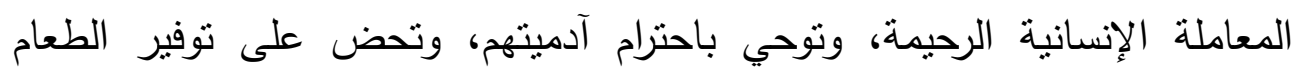

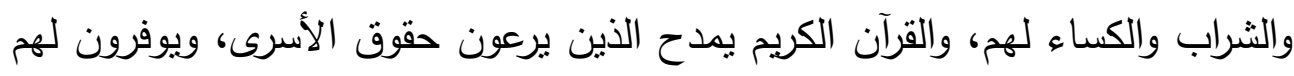

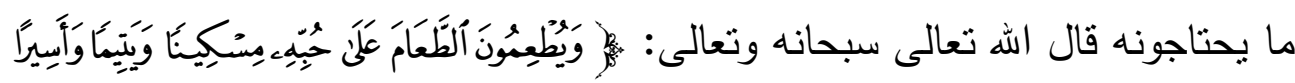

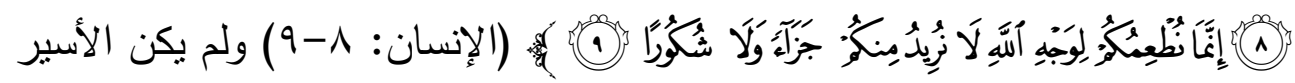
حين نزلت الآية إلا من المشركين. ولو ذهبنـا نستعرض تعـاليم الإسـام بشـأن ضـمان حقوق الأسـرى والإحسـان

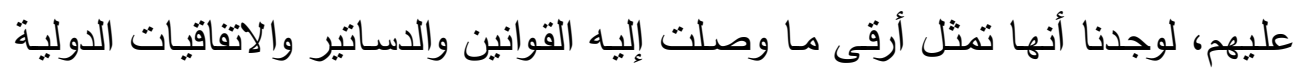

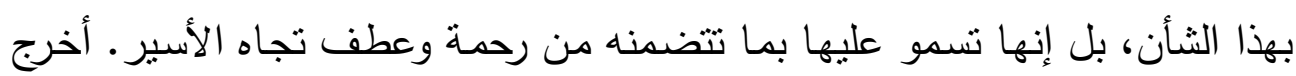

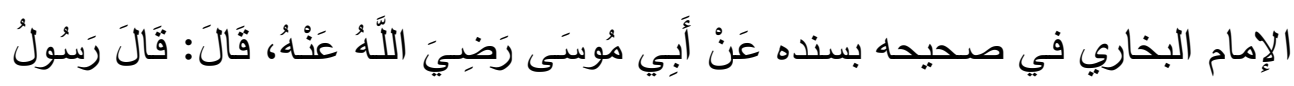

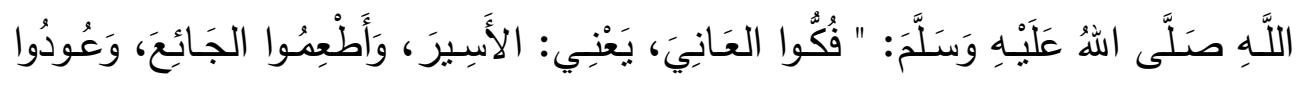

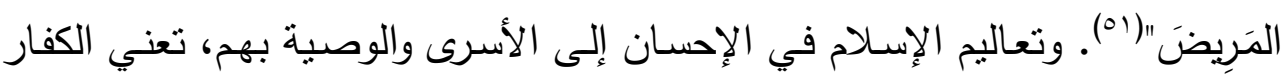

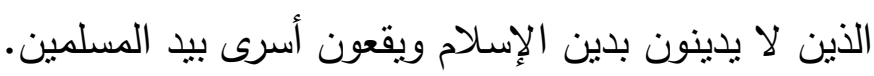
المطلب الرابع: الإحسان إلى الأطفال والنساء والشيون الإنيوخ والرهبان: وقد دعا الإسلام إلى الإحسان إلى أطفال غير المسلمين وإلى نسائهم وشيوخهم

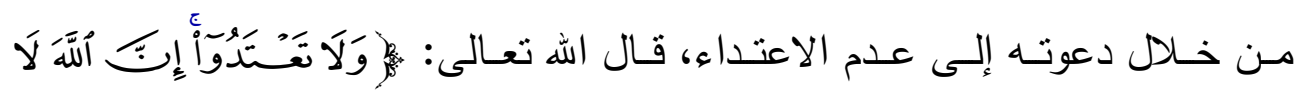

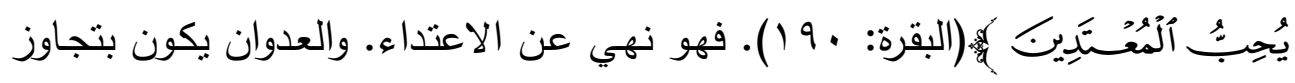
المحاربين المعتدين إلى غير المحاربين من الآمنين المسالمين الذين لا يشكلون خطراً

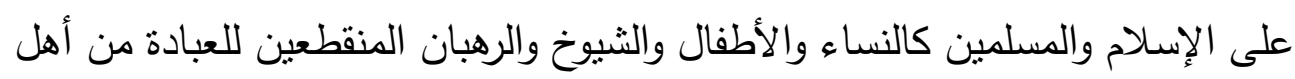

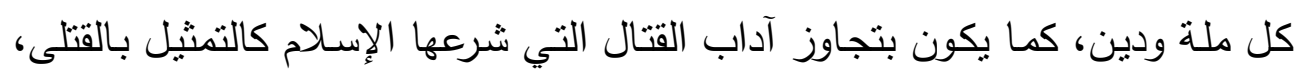




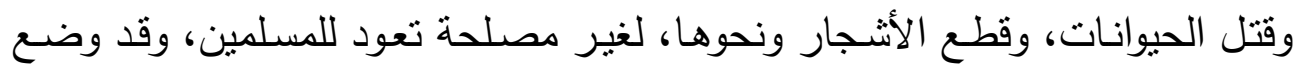

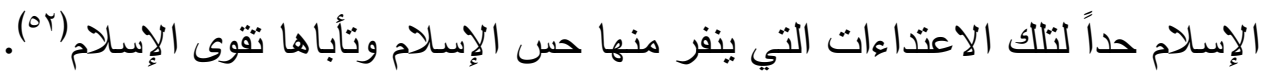

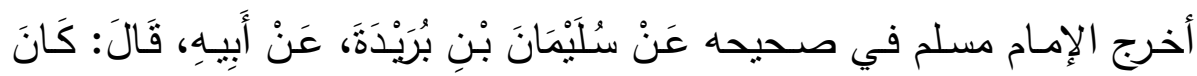

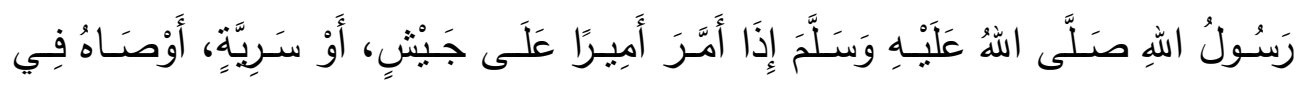

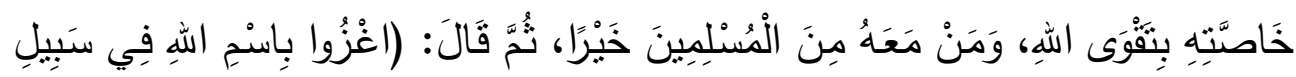

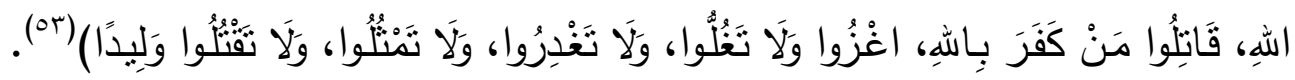

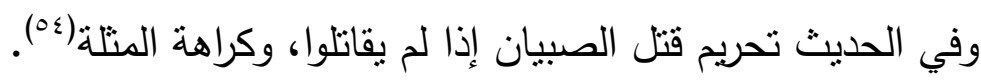

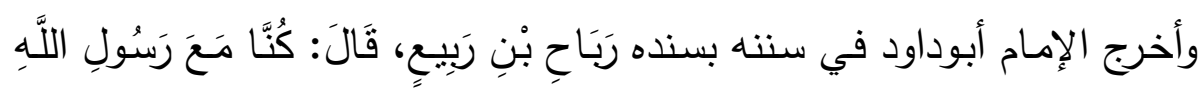

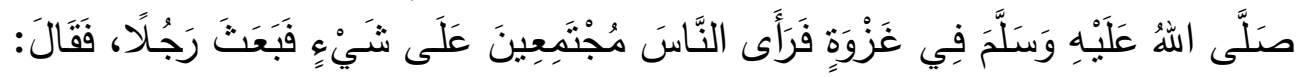

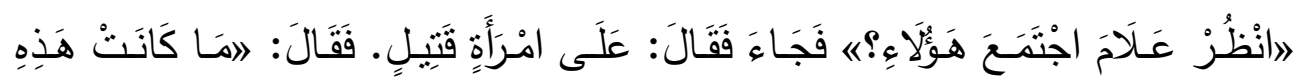

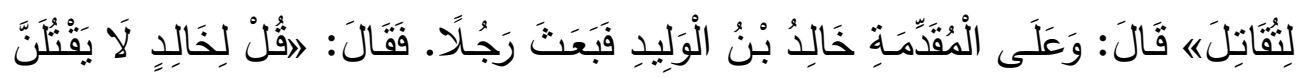

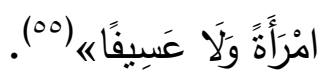

وهذا أبوبكر رضي الله عنه يوصي يزيد بن أبي سفيان حين وجهه إلى الثـام

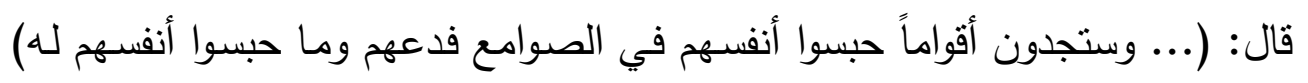

\section{المطلب الخامس: الحرية الدينية:}

من المبادئ الأساسي التي جاءت الدية: بها الثـريعة الإسـلامية مبدأ الحريـة، فقد

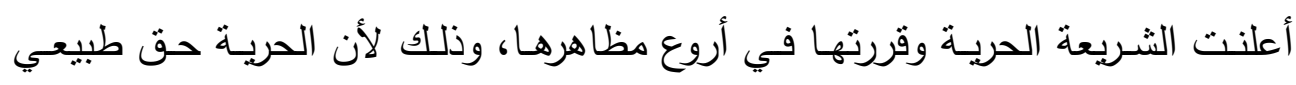
مقدس، ومظهر فطري ينبثق من الفطرة السليمة الني منحها الله للإنسان، يولا حراً،

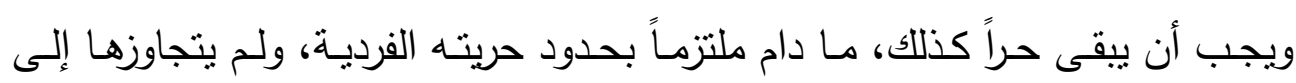
الإضرار بالآخرين.

والحريـات العامـة: هي حقوق لصـيقة بالإنسـان ملازمـة لـه، لا يجوز حرمانسه منها، ويعتبر المساس بها مساس بشخصية الإنسان وآدميته.

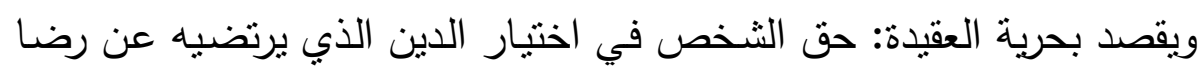


واقتتاع وبلا إكراه. وهي أبرز مظهر من مظاهر حرية الإنسان، حريته فيما يدين بـه

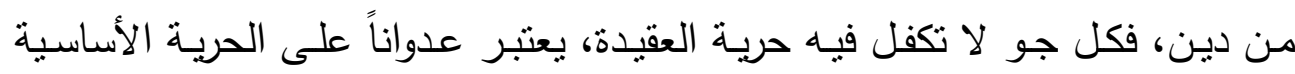

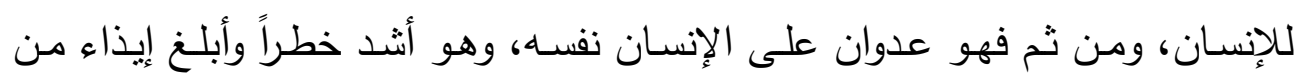

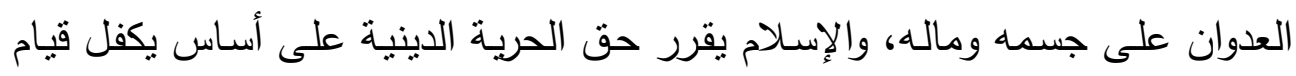

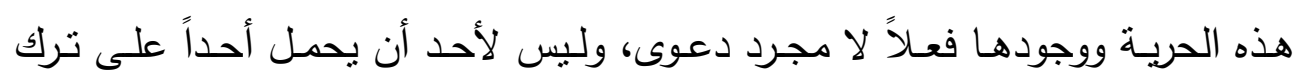

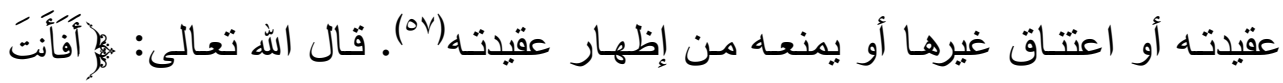

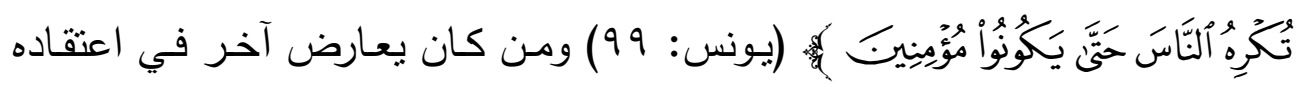

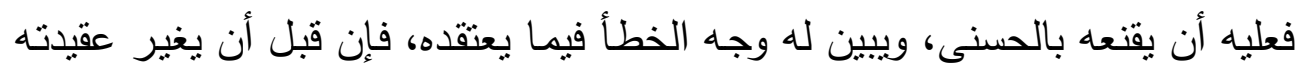

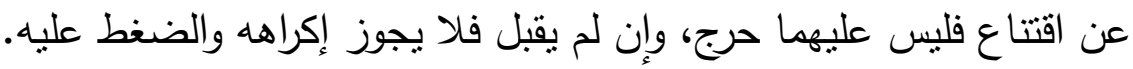

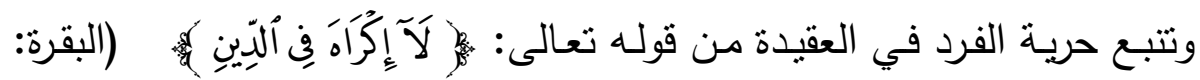

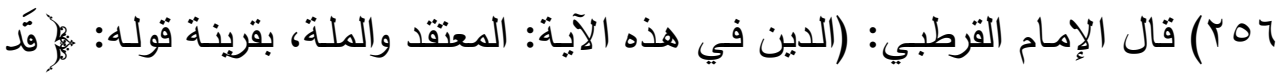

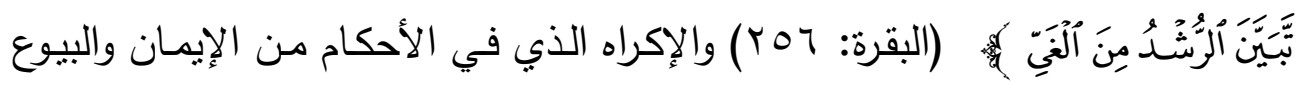

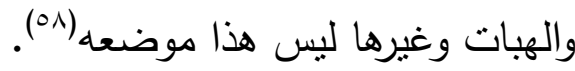
وقد ثبت أن النبي لئ خاطب غير المسلمين ودعاهم إلى الإسـلام، وترك لهم

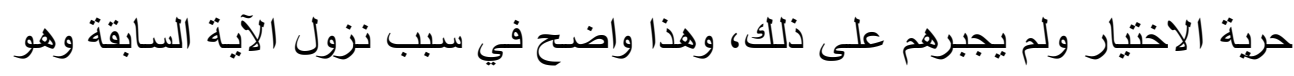

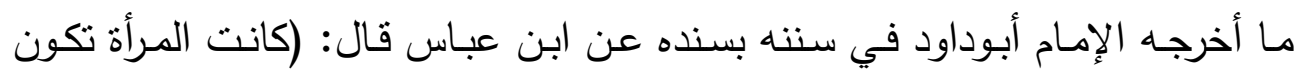

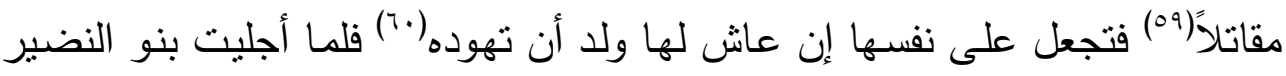

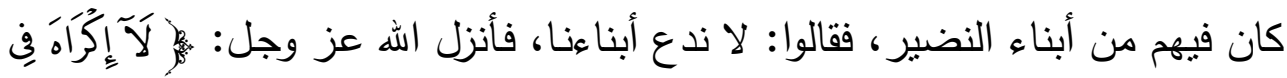

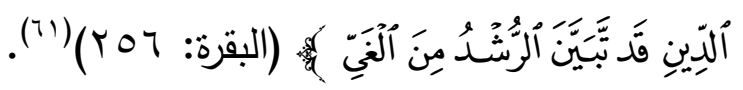

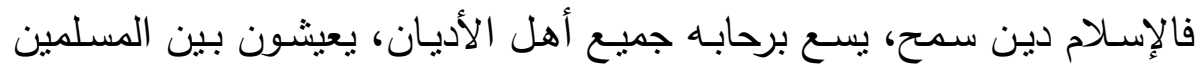

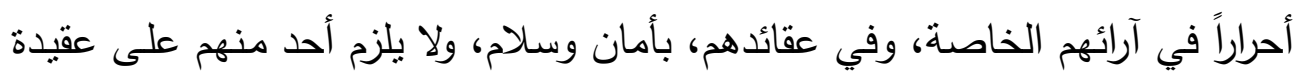

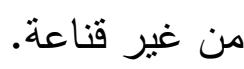
المطلب السادس: التعامل معهم أخذاً وعطائ: 
ولم يقتصر النبي

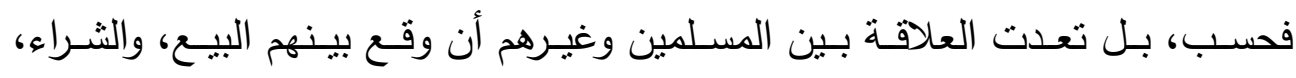

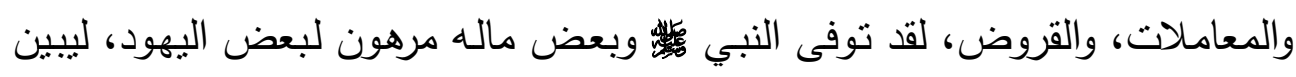
لنا جواز التعامل مع غير المسلمين.

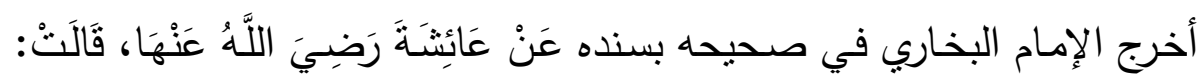

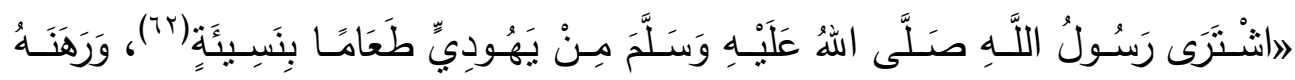

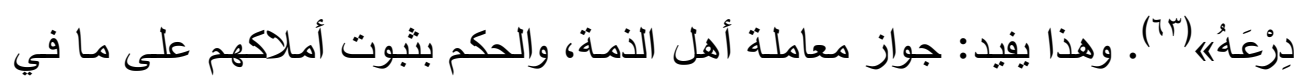

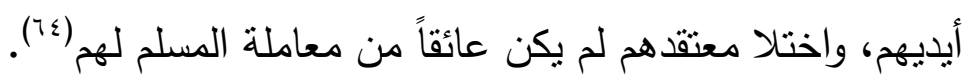

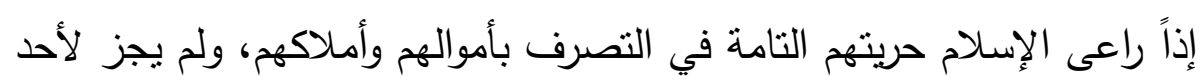

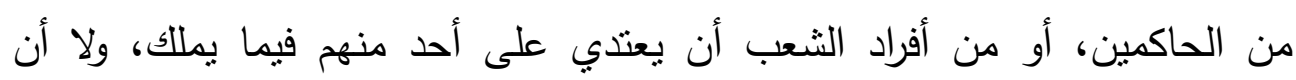

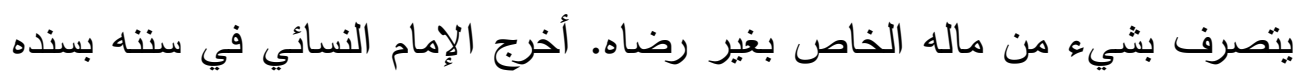

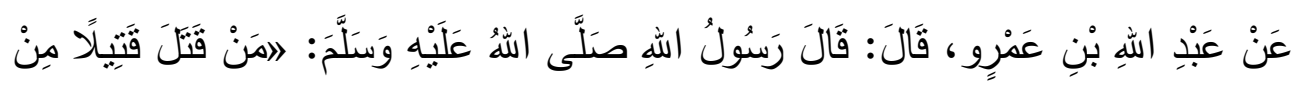

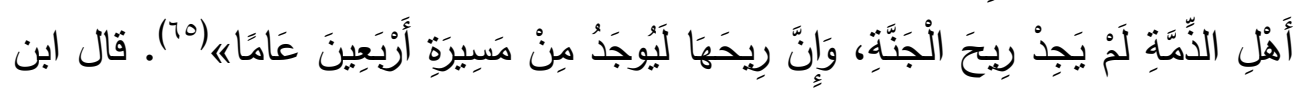

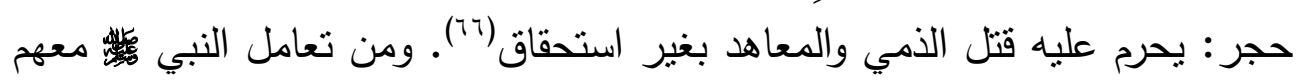

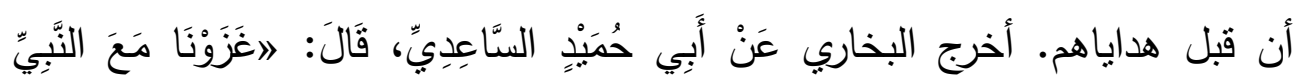

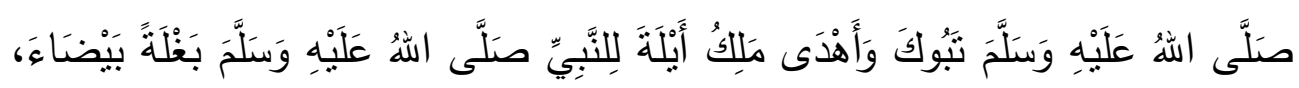

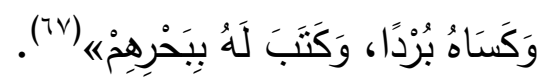

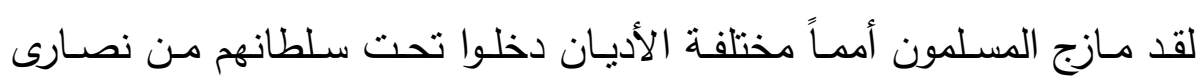

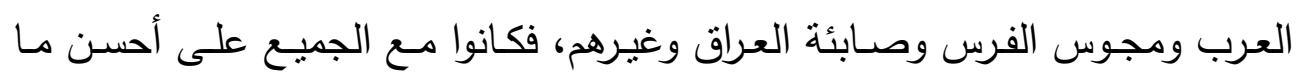

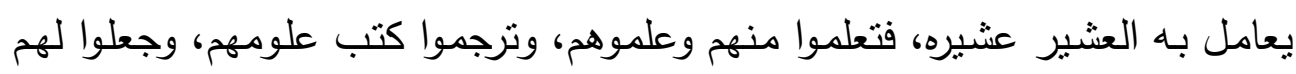
الحرية في إقامة رسومهم، واستبقوا لهم عوائدهم المتولدة من أديانهم.

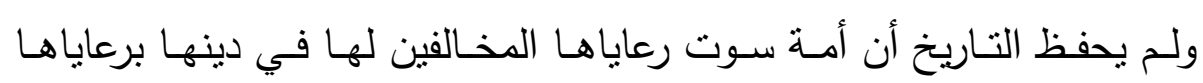

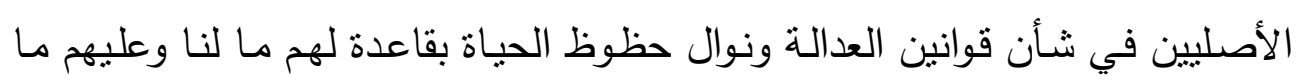


علينا مع تخويلهم البقاء على رسومهم وعاداتهم، مثل أمة المسلمين فحقيق هذا الذي

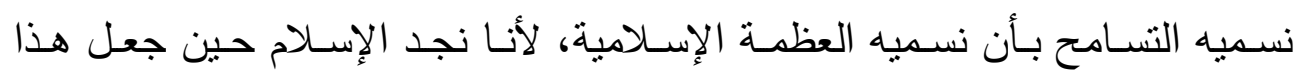

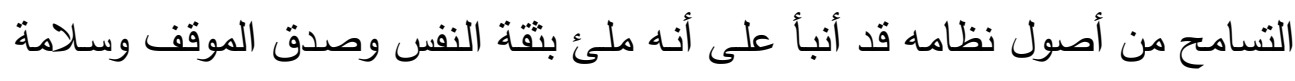

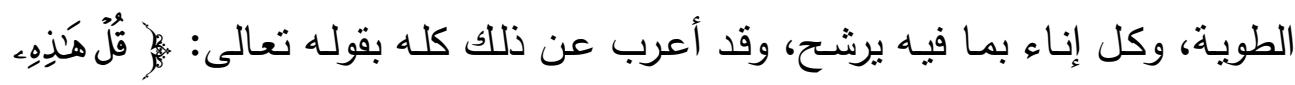

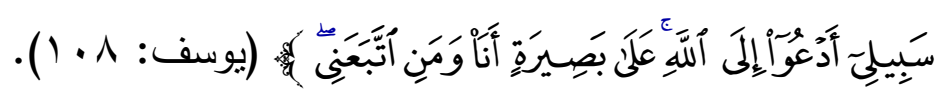

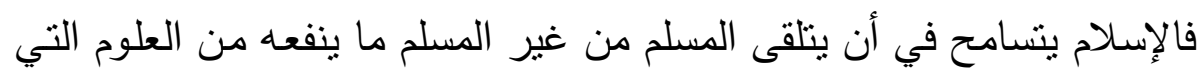

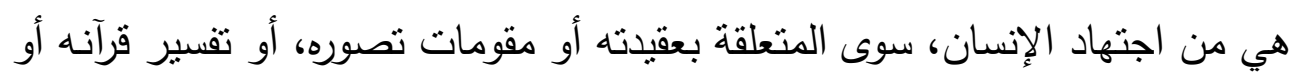
سنة نبيه المطلب السابع: حماية من طلب الجوار منهم:

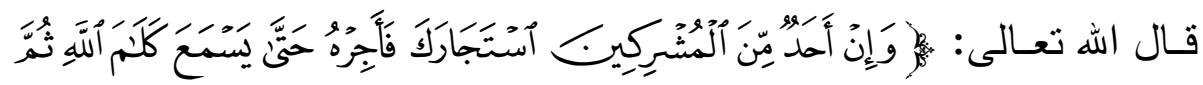

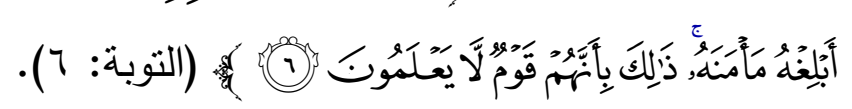

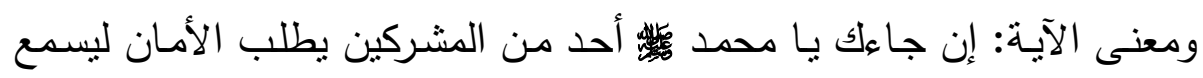

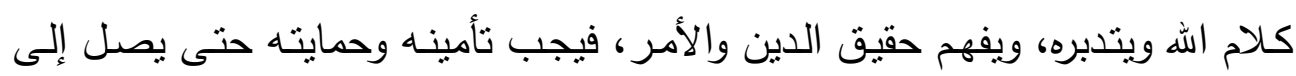

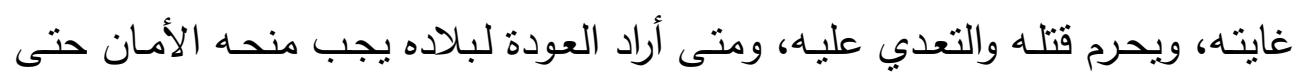

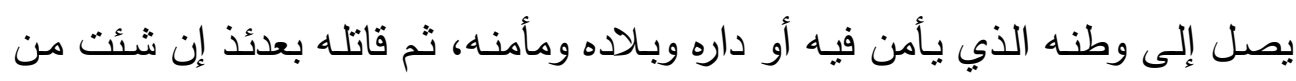
غير غدر ولا خيانة(19). وهذا معناه: أنه يجب على الإمام حماية الحربي المستجير، وصون دمه وماله

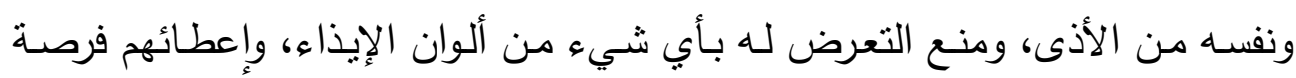

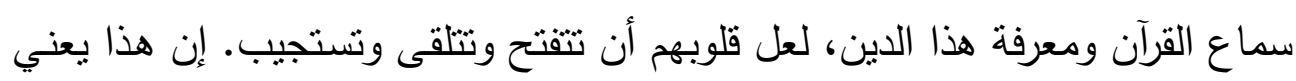

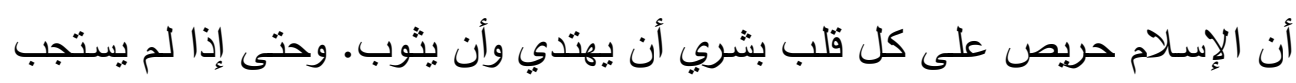

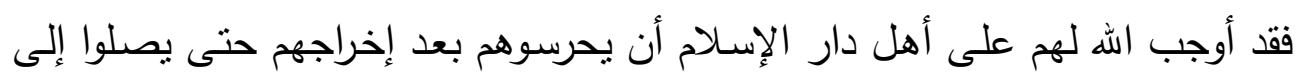
بلد بأمنون فيه على أنفسهر. وسبب هذا التسامح المفهوم من الأمر بإجارة المستجير في قوله تعالى: (فأجره) 
وإبلاغه مأمنه، هو أن هؤلاء المشركين قوم جهلة، لا يعلمون حقيقة الإسلام وما يدعو

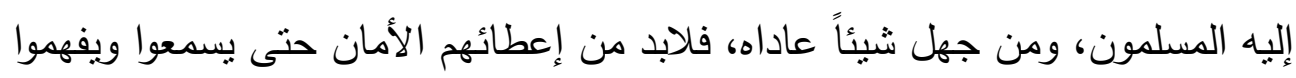
الحق.

وبنـاء عليه كان رسول الله

رسالة.

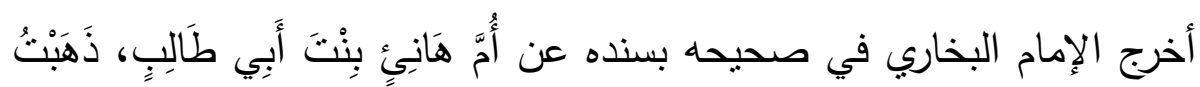

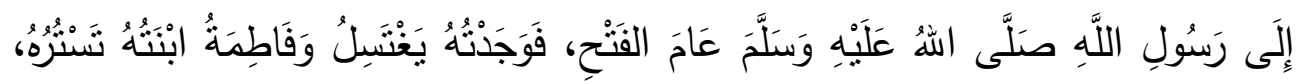

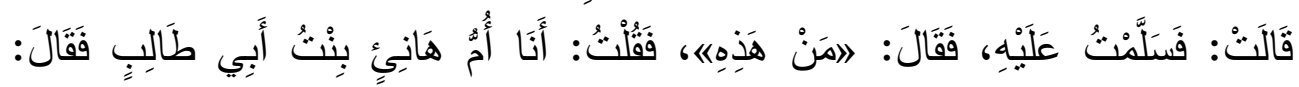

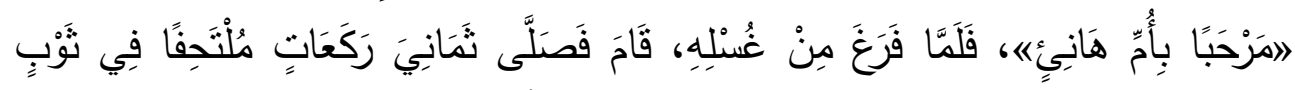

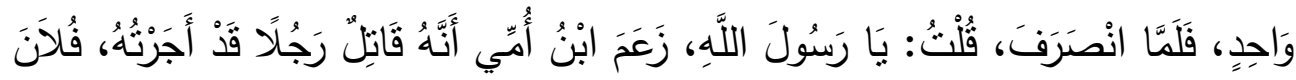

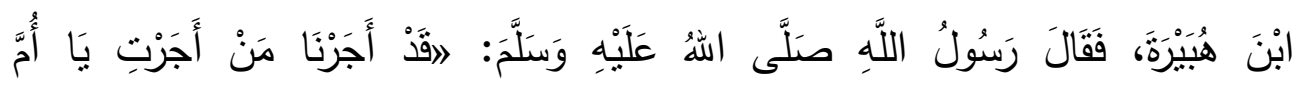

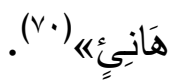

قال ابن كثير : والغرض أن من قدم من دار الحرب إلى دار الإسـلام في أداء

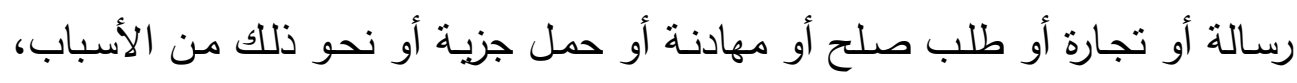

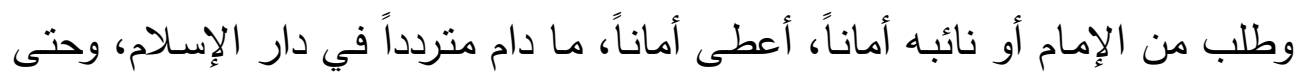

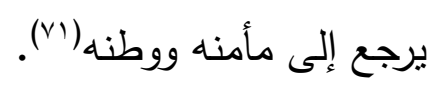

ونص الحنفية(Vr) والثافعية(Vr) وغيرهم على أن الحربي إذا دخل دار الإسـلام

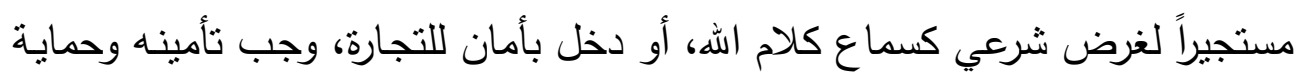
نفسه وماله، على أن يبلغ داره التي يأمن فيها.

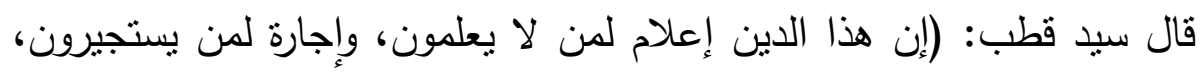

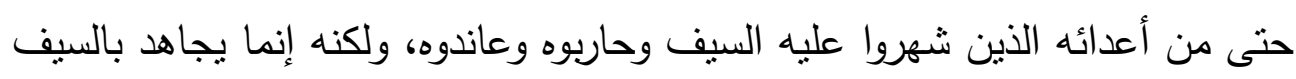
ليحطم القوى المادية التي تحول بين الأفراد وسماع كلام الله؛ وتحول بينهم وبين العلم

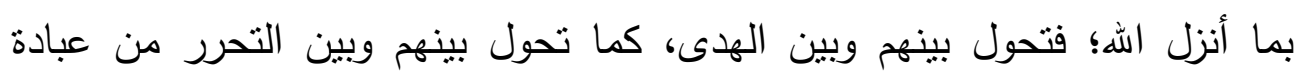


العبيد؛ وتلجئهم إلى عبادة غير الله ومتى حطم هذه القوى، وأزال هذه العقبات، فالأفراد

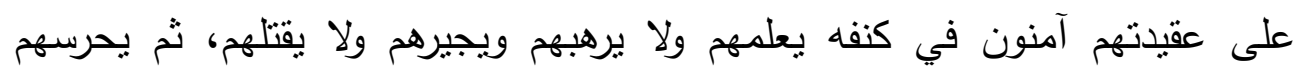

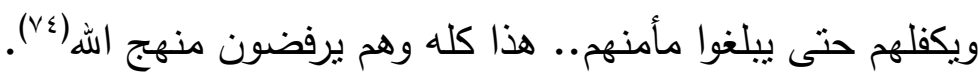

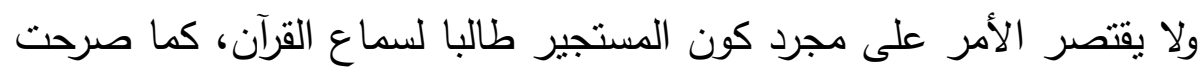

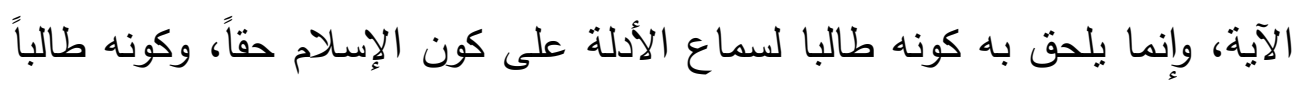
الجواب عن الثبهات التي عنده لأن كل هؤلاء يطلبون العلم ويسترشدون عن الأنه

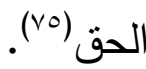

\section{المطلب الثامن: الوفاء بالعهد معهم:}

ومن سماحة الإسلام مع المخالفين في الدين الوفاء بالعهُ معهم، أما إذا أراد

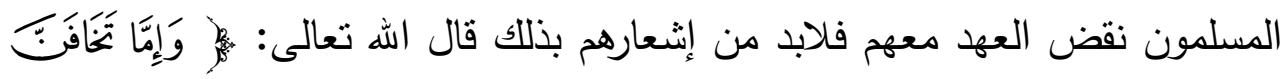

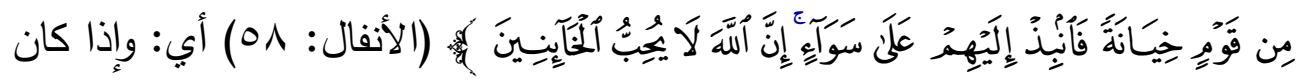
بينك وبين قوم عهد وميثاق على نرك القتال فخفت منهم خيانة، بأن ظهر من قرائن إنى

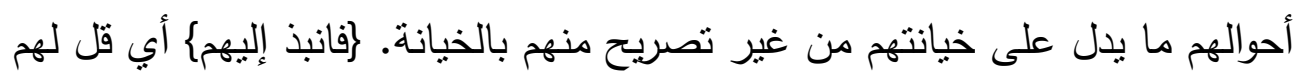

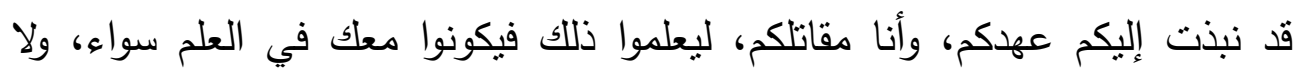

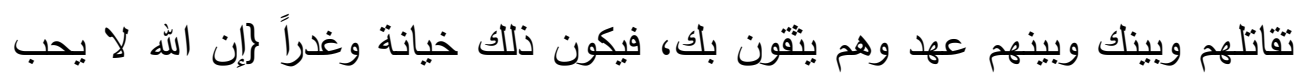

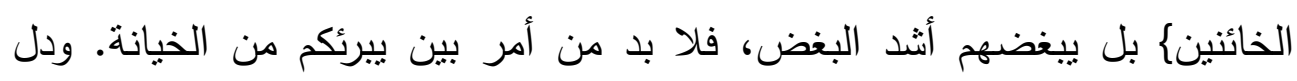

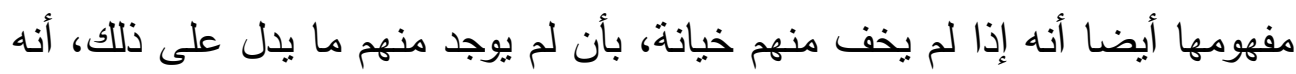

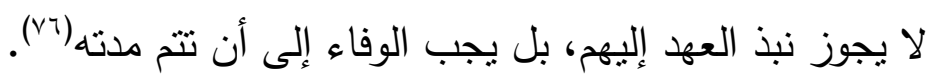

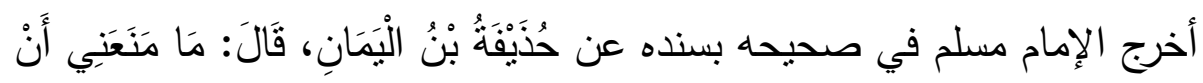

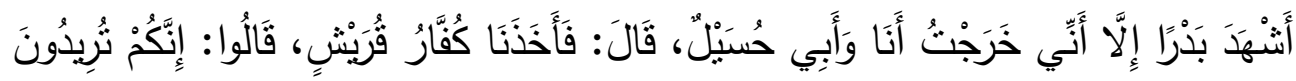

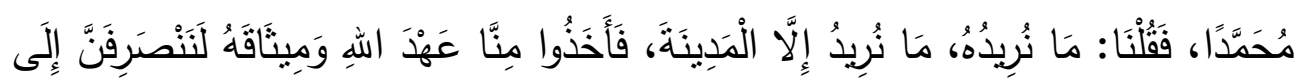

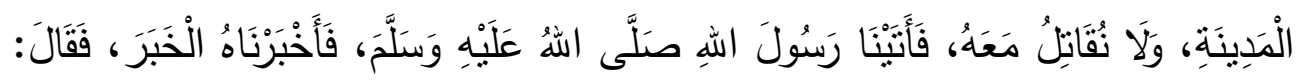

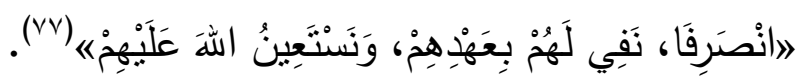


فالنبي صلى الله عليه وسلم لم يأذن لحذيفة ولا لأبيه بأن يخرجا مع المسلمين في موقعة بدر الكبرى، في وقت كان النبي لئس فيه بحاجة إلى الرجال، وذللك: وفاء

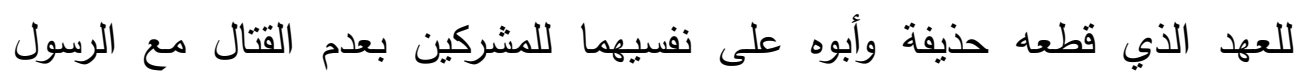
وأصحابه.

قال النووي: (فأمرهما النبي

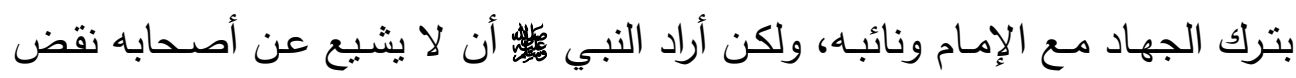

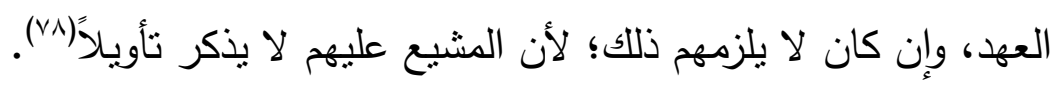

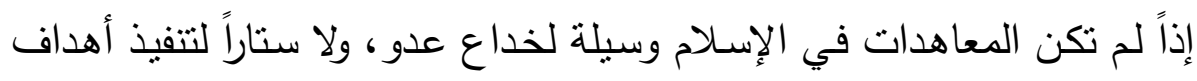

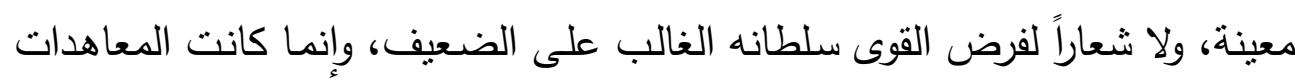

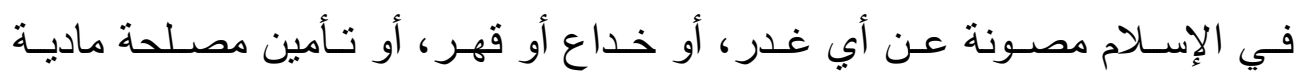
رخيصة.

إن الإسلام يعتبر البدء بنقض العهد غدراً، سواء أكان عهداً مع المسلمين أو

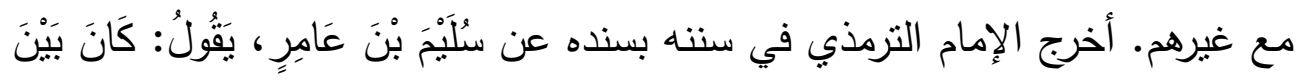

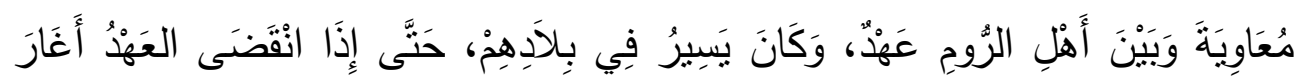

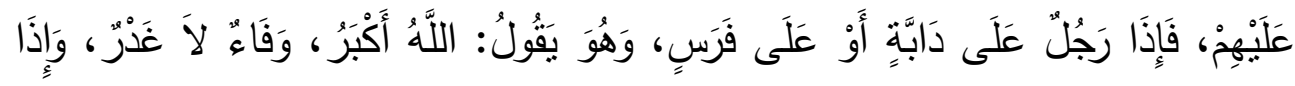

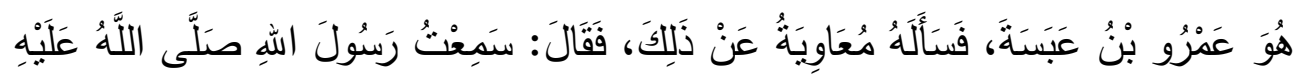

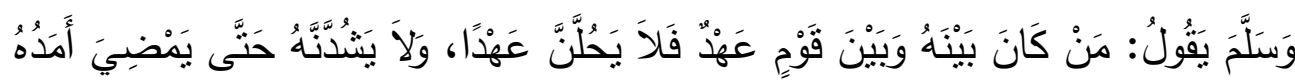

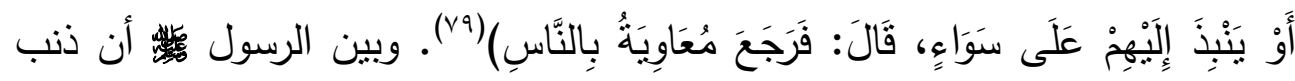

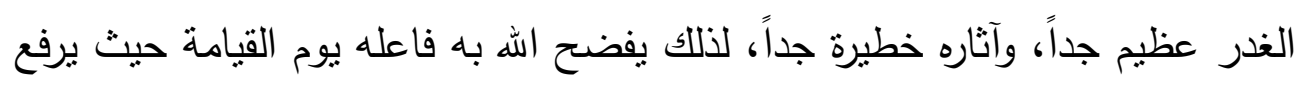
له فضيحة بقدر غدرته، يقال هذه غدرة فلان. أخرج الإمام التزمذي في سنته بسنداه

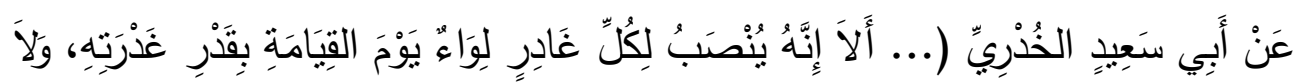

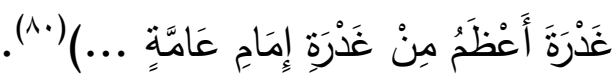


قال القرطبي: قال علماؤنا: إنما كان الغدر في حق الإمام أعظم وأفش منه

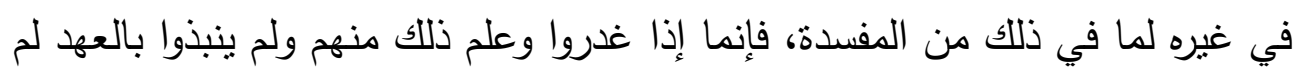

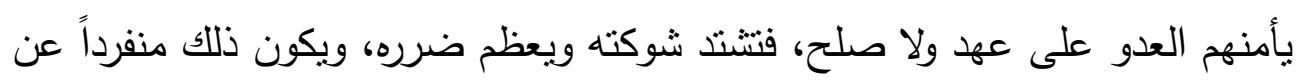

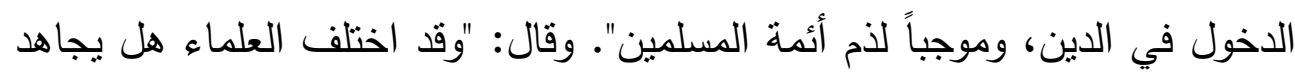

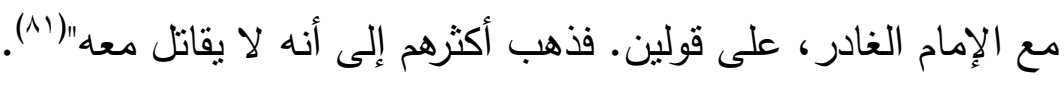

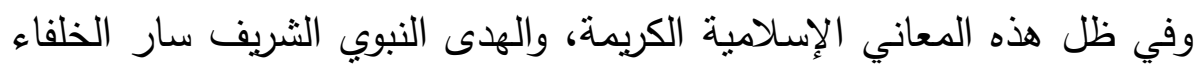

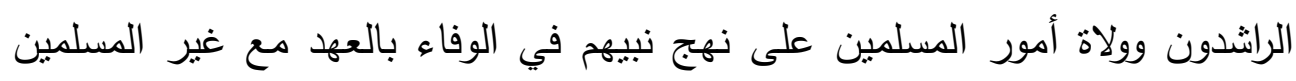

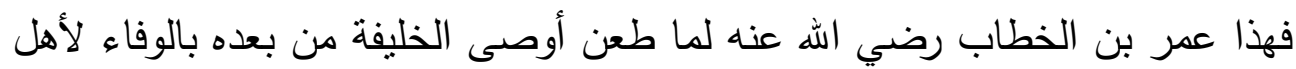

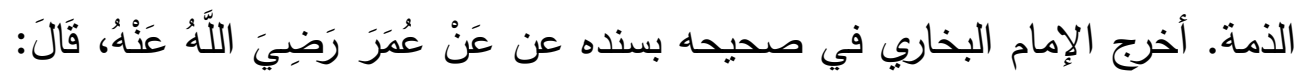

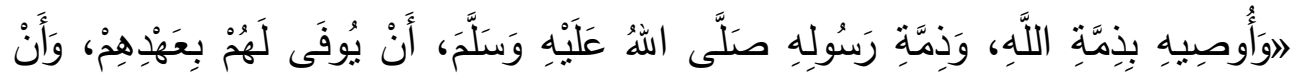

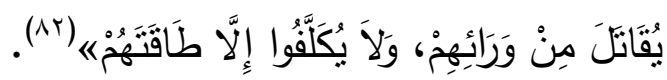




\section{الخاتمة:}

$$
\begin{aligned}
& \text { أهم النتائج والتوصيات: } \\
& \text { أولاً: النتائج: }
\end{aligned}
$$

1- إن الدعوة بالأفعال أجدى، وأنفع، وأثند أثثراً من الدعوة بالأقوال، وأن خير

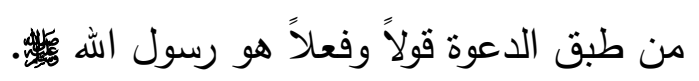

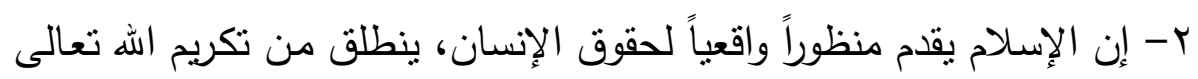

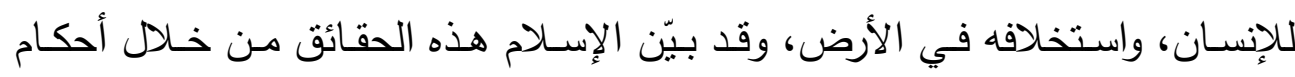

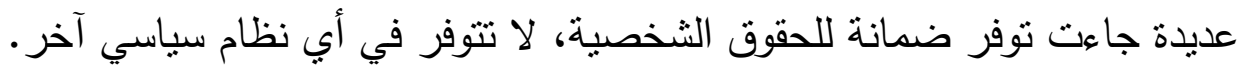

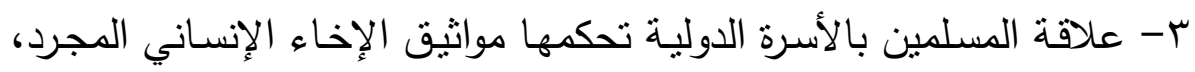
والمسلمون دعاة لدينهم بالحجة والإقناع فحسب، لا يضمرون شراً لعباد الله.

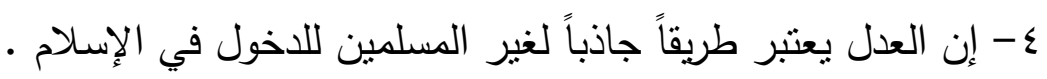

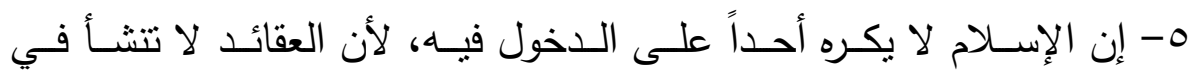

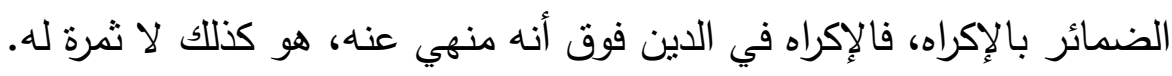

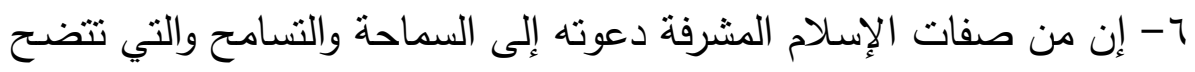
في معاملاته مع غير المسلمين من إحسان القول لهم، والإحسان إلى أسراهم وشيخهم الإنها

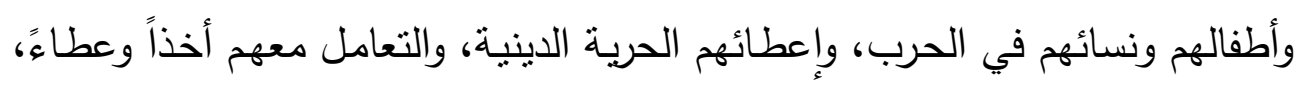

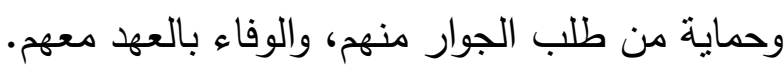

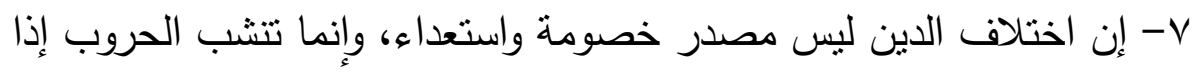

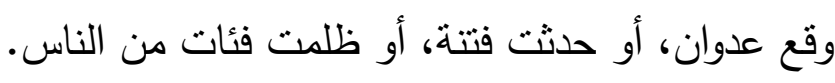
ثانياً: التوصيات:

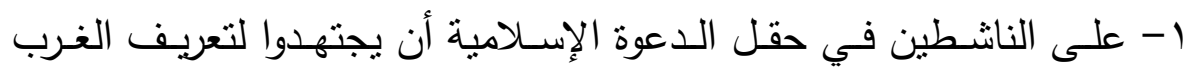
بالإسلام، وأن يرفعوا من أمام الغربيين حواجز الخوف من الإسلام، ويطلعونهم على الإنى حققتته الحضارية والإنسانية. r- توسيع قاعدة الحوار والتعاون مع المتتورين من الغرب، ونقدم لهم الدعم 
ليتمكنوا بدورهم من المساهمة في تصحيح العلاقة بين الإنسام والغرب.

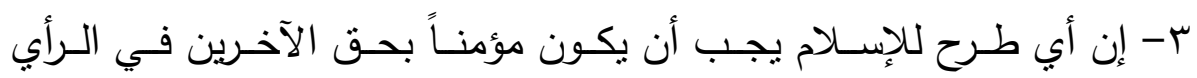

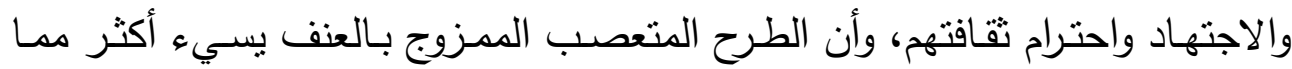
يحسن، وينعكس سلباً على الجهود الدعوية في تحقيق العودة إلى الإسلام. ع- إنشاء معاهد وكليات لإعداد الدعاة من المسلمين الجدد بلغات مختلفة، وتأهيلهم ليكونوا سفراء الإسلام إلى أقوامهم. 


\section{الهوامشیs}

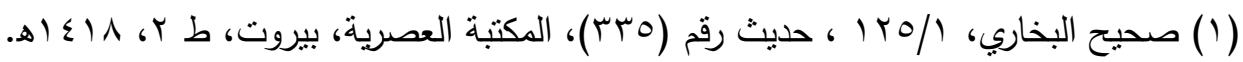

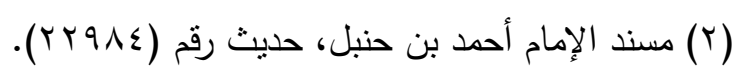

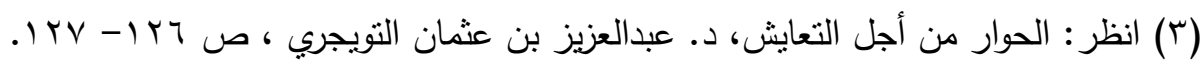

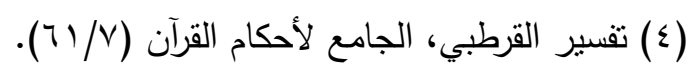
(0) صحيح البخاري، محمد بن إسماعيل البخاري، حديث رقم (1) (1) (1).

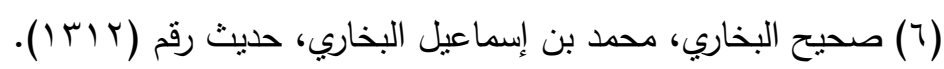

انظر : تاريخ الخلفاء ، عبدالرحمن بن أبي بكر السيوطي، تحقيق محمد محيى الدين (V)

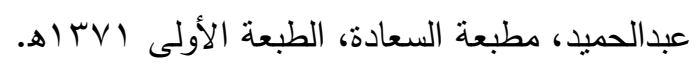

(^) انظر : الخصائص العامة للإسلام، يوسف القرضاوي، الطبعة العاشرة ، مؤسسة الرسالة

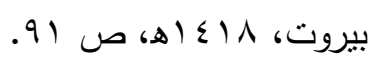

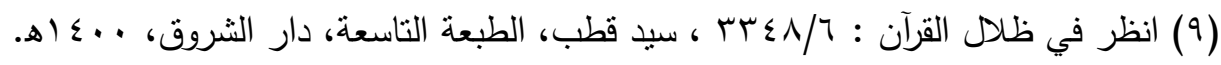

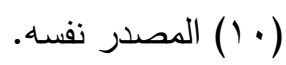

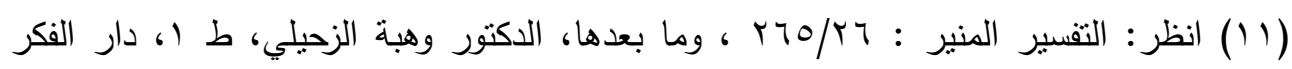

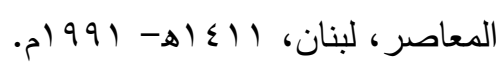

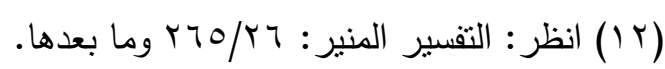

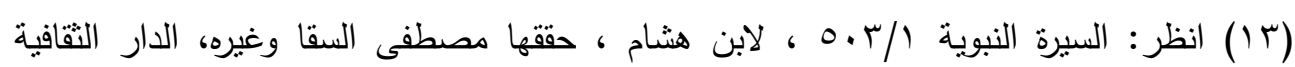
العربية، بيروت.

(ء () فتح الباري : ؟/. rس ، للحافظ أحمد بن حجر العسقلاني، تصحيح وتحقيق عبدالعزبز بن باز ، دار المعرفة، بيروت.

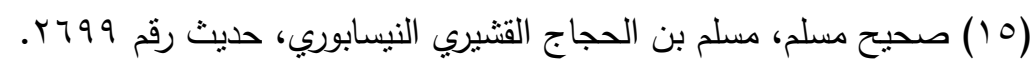

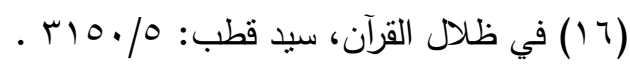


(V) الحكومة الإنلامية، لأبي الأعلى المودودي، نقله إلى العربية : أحمد إدريس، المختار

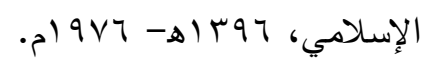

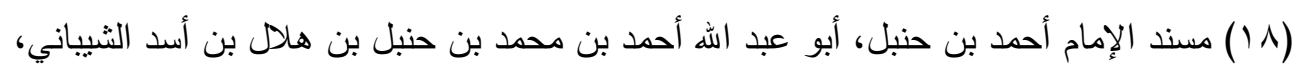

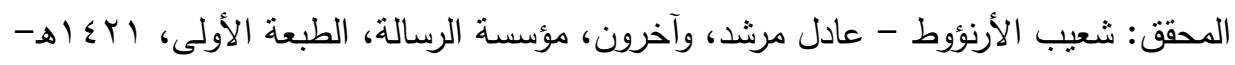

$$
\text { (19) }
$$

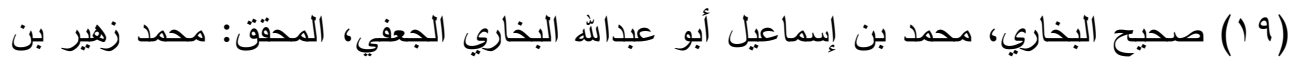

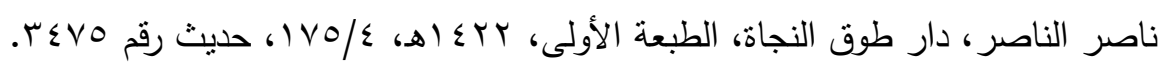

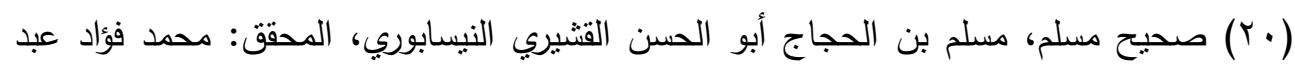

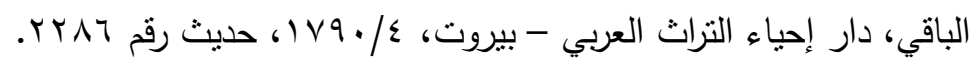

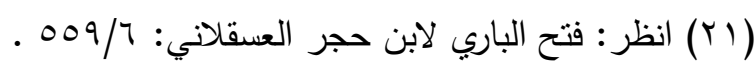

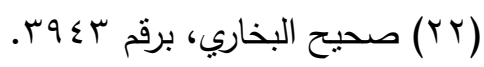

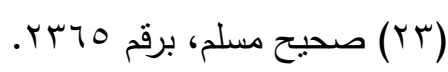

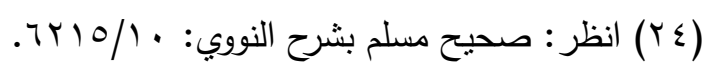

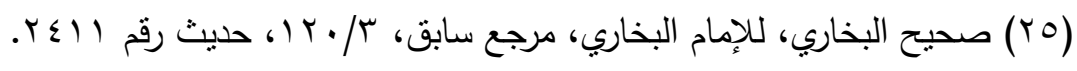

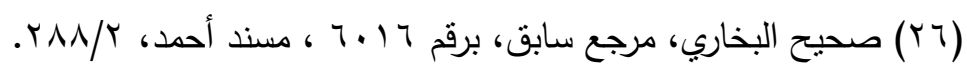

(YV)

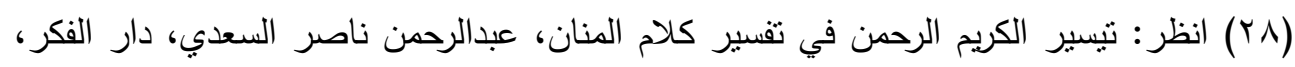

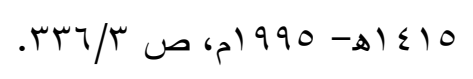

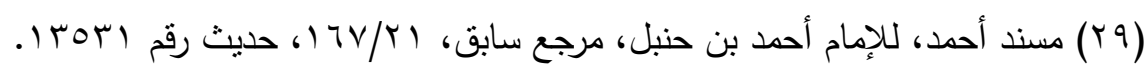

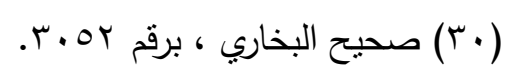

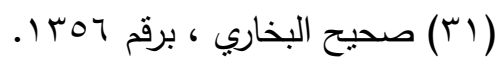

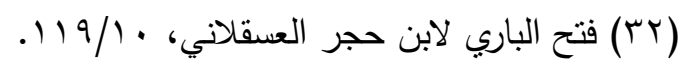

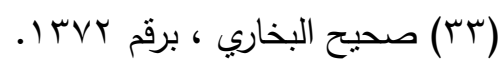

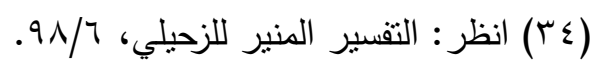


(ب0)في ظلال القرآن، سيد قطب إبراهيم حسين الثاربي، دار الثروق - بيروت- القاهرة، الطبعة

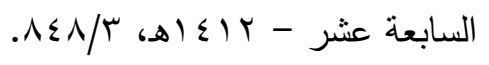

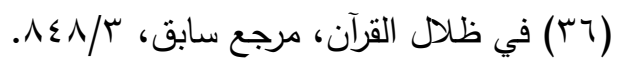

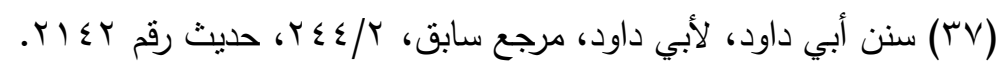

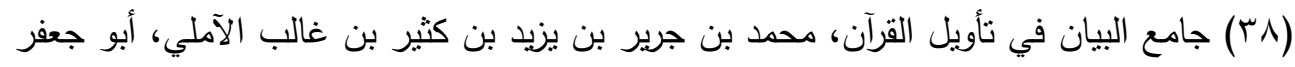

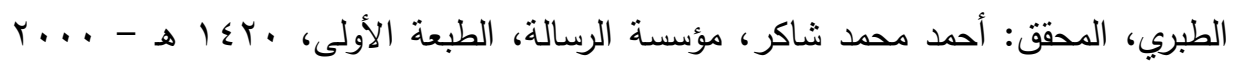

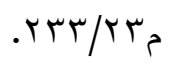

(Yq) أحكام القرآن ،محمد بن عبداله المعروف بابن العربي، تحقيق وتخريج :محمد عطا،

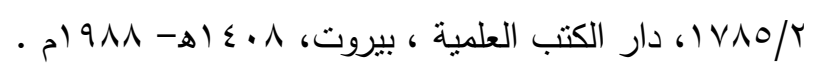

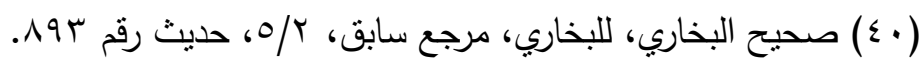

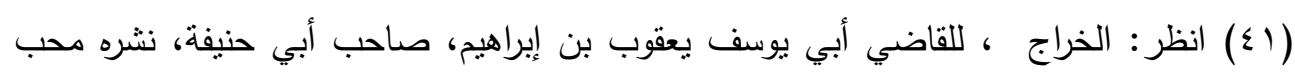

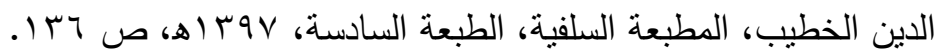

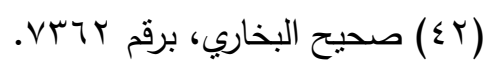

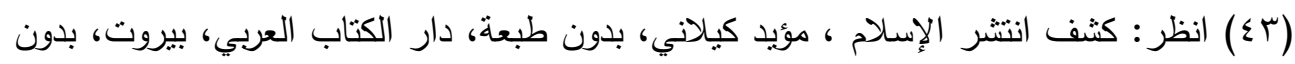

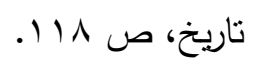

( ع §) انظر : تفسير القرآن العظيم، ابن كثير، الطبعة الثانية، دار القلم ، بيروت. (20) انظر: من أسرار المنهج الرباني، محمد سعيد البوطي، الطبعة الثانبة، مؤسسة الرسالة،

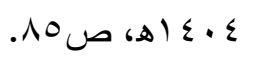

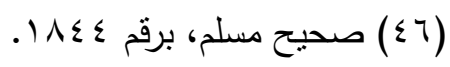

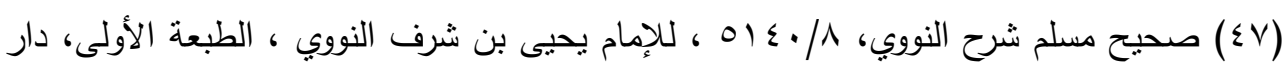

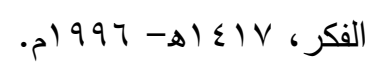

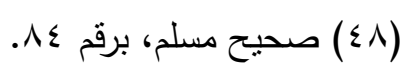

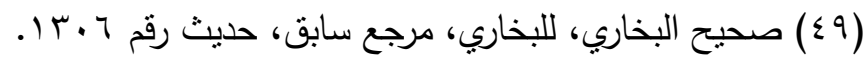

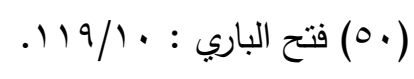


(10) صحيح البخاري، برقم ؟؟ • ب، وعودوا المريض: تعنى : أي زوروا المريض، انظر : النهاية

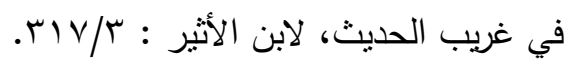

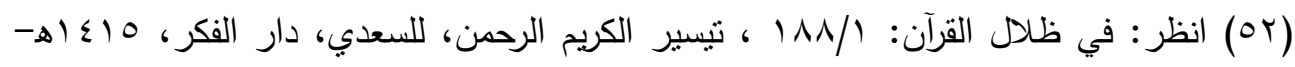
. 1990

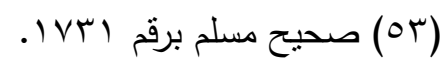

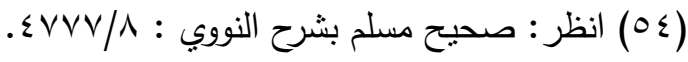

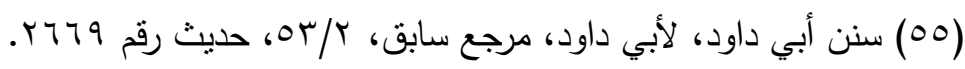

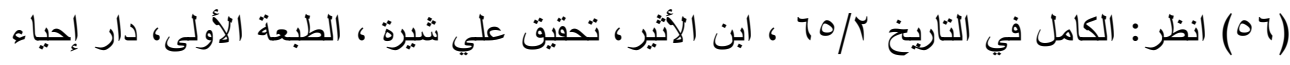

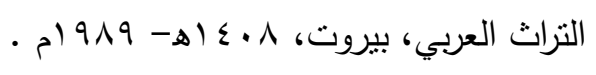

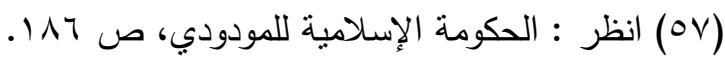

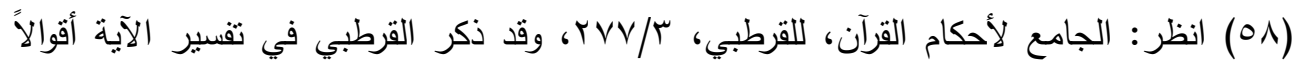
أخرى.

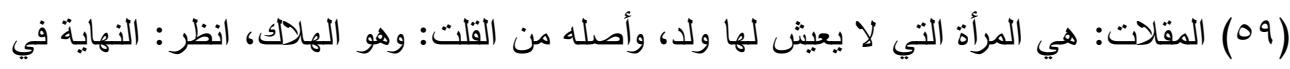

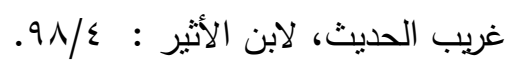

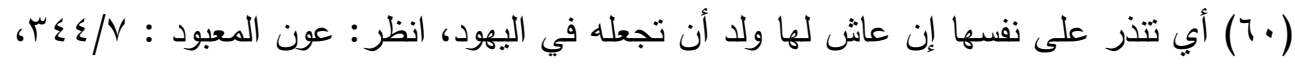
لثمس الحق العظيم أبادي، تحقيق عبدالرحمن عثمان، دار الفكر.

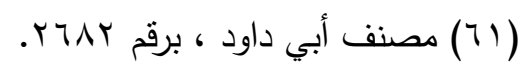

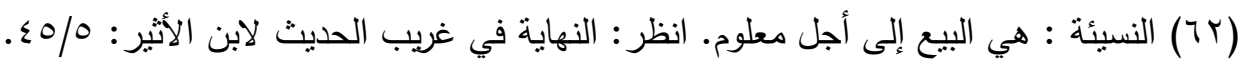

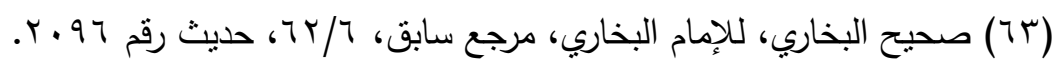

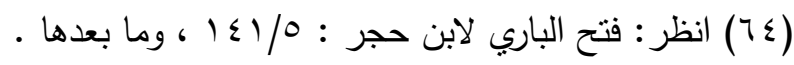

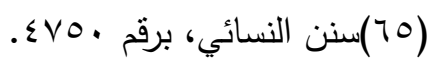

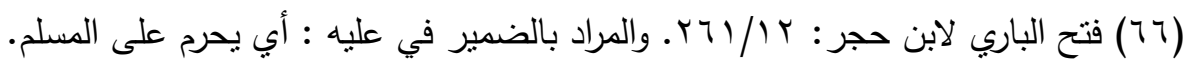

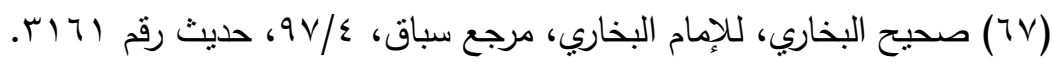

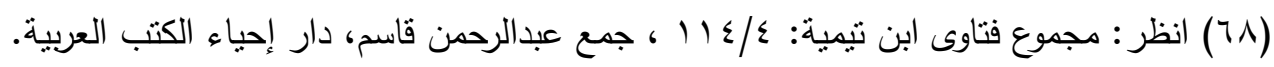




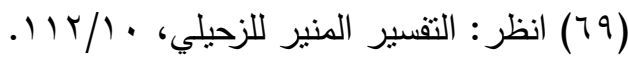

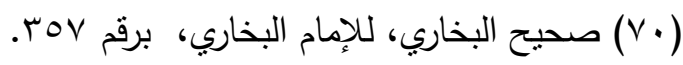

، تقسير القرآن العظيم، لابن كثير، اختصار تحقيق محمد الصابوني، دار القرآن الكريم ل) (Y)

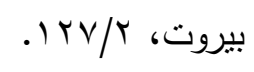

(VY)

$$
\text { الفكر العربي، بيروت. }
$$

(VT)

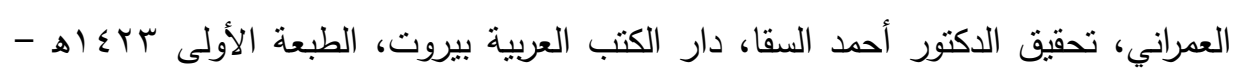

$$
\text { . }
$$

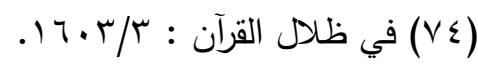

(Vo)

(VT)

. IVAV صحيح مسلم، برقم (VV)

$$
\text { (V^) }
$$

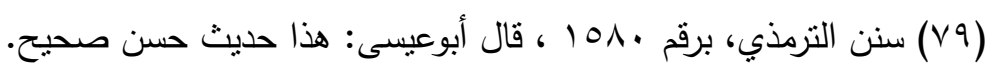

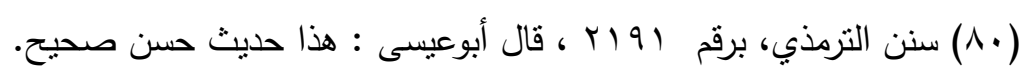

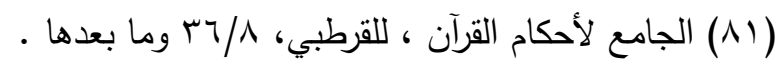

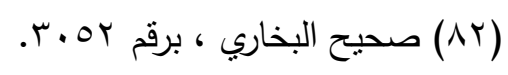




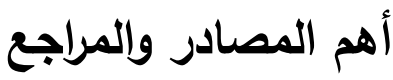

ا . ابن تثمية، مجموع الفتاوى، جمع عبدالرحمن قاسم، دار إحياء الكتب

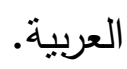

r. أبي الفداء إسماعيل بن كثير ، تفسير القرآن العظيم، اختصار وتحقيق:

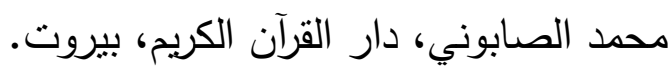

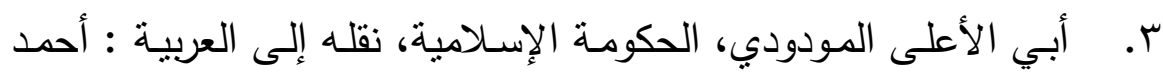
إدريس، المختار الإسلامي، 94 (اهـ- 9V7 ام.

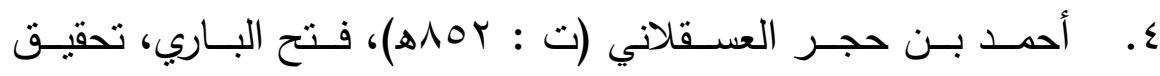
عبدالعزيزبن بارز، دار المعرفة، بيروت.

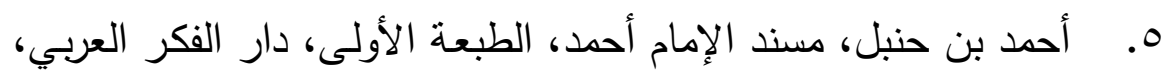

$$
\text { .ه } 180
$$

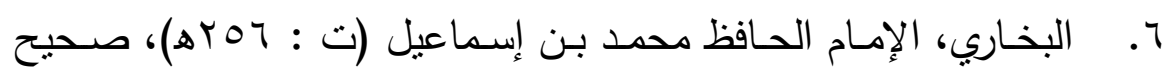

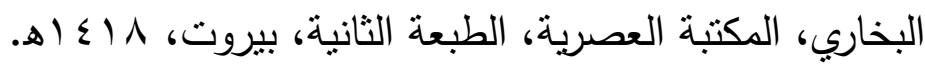

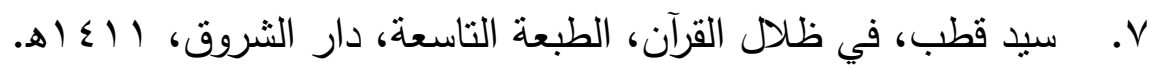


^. عبداله علـوان، سلسـلة مدرسـة الـدعاة، الطبعـة الأولى، دار السـلام، - ) $99 \mathrm{~V}$

9. عبـدالرحمن حسـن الميـداني، الأخـلاق الإسـلامية وأسسـها، الطبعـة

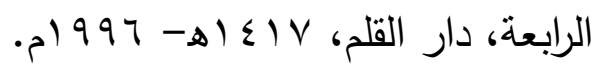

• 1. عبدالرحمن ناصر السعدي (ت : דVr (ه)، تيسير الكريم الرحمن في

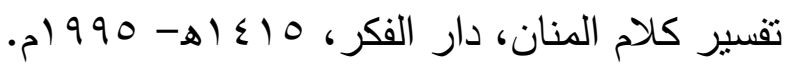
ا1. عبدالعزيز بـن عثــان التويجري، الحـوار مـن أجـل التعـايش، (بـون ناربخ) r ا. ـ علي بـن أبـي المكـارم الثـيباني المعـروف بـابن الأثيـر، الكامـل في التاريخ، تحقيق: علي شيري، دار إحياء التراث العربي، بيروت، الطبعة

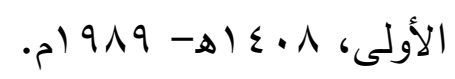

سا . علي محمد الصـلابي ، فصل الخطاب في سبرة عمر بن الخطاب،

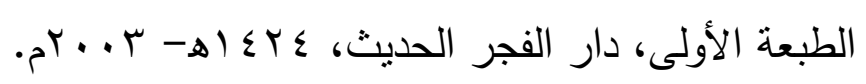

ع ا. . مسلم، الإمام الحافظ مسلم بن حجاج النيسابوري (ت (اTYه)، صحيح مسلم، بيت الأفكار الدولية، الرياض، 9 (اء اهـ. 1. . محمد بن جرير الطبري (ت : . اساه)، تاريخ الطبري، الطبعة الأولى، دار الكتب العلمية، بيروت، V • ـ إهـ

1 ا. محمد بـن أحمد القرطبي، الجـامع لأحكام القرآن، راجعهـ: د. محمد

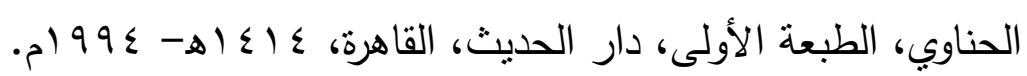


V V.. محد الرازي، فخر الدين الرازي (ت ع • جه)، تفسير الفخر الرازي، الطبعة الثالثة، دار الفكر، 0. ــ الهـ

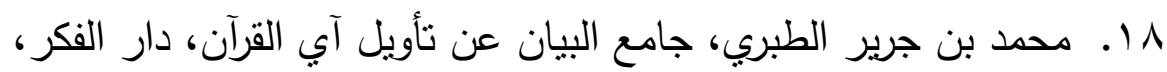
ه 1 . 1

19 1. محمد حميد الله، مجموعـة الوثائق السياسية للعهد النبوي والخلافـة

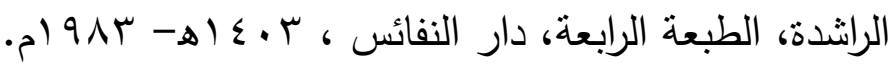

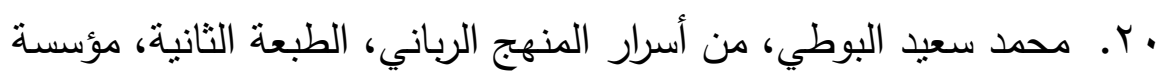
الرسالة، ع - ـ اله.

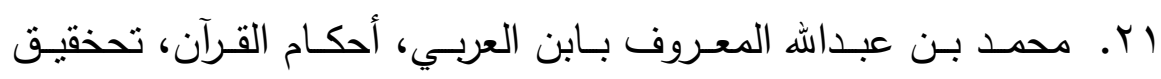

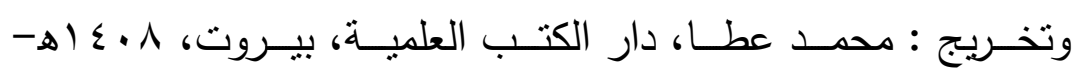
.01911

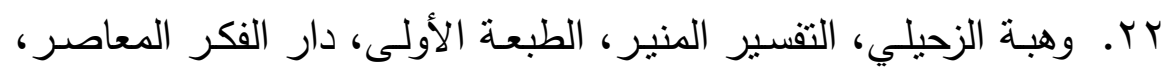

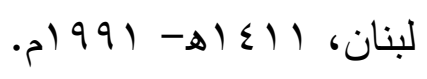

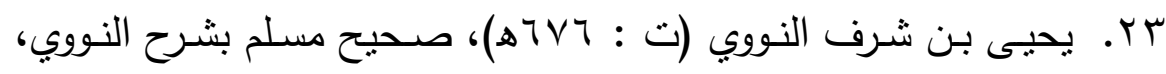

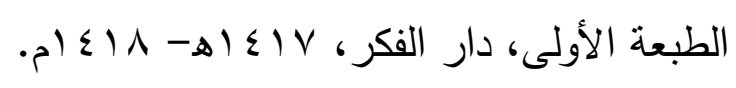

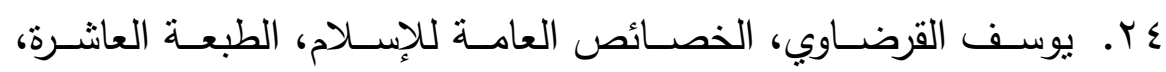

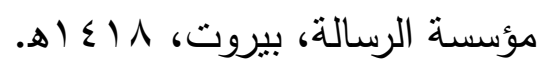

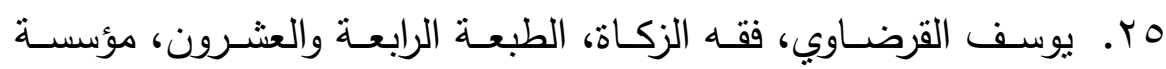

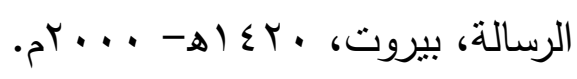

